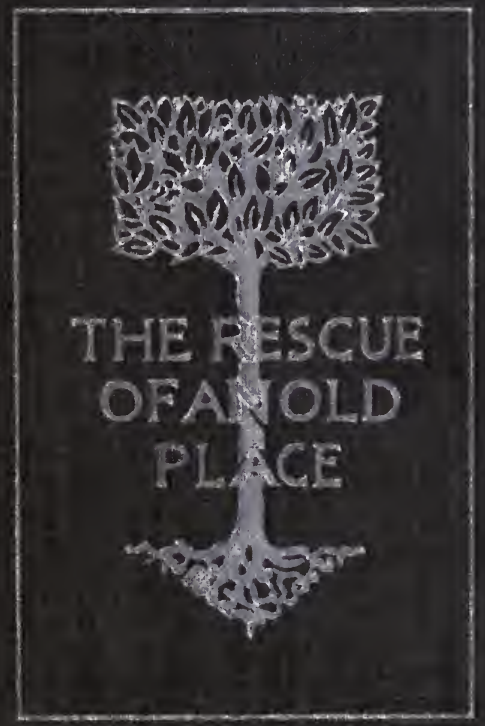








\title{
THE RESCUE OF AN OLD PLACE
}

\author{
BY \\ MARY CAROLINE ROBBINS
}

When Epicurus to the world had taught

That pleasure was the chiefest good, (And was perhaps i' the right, if rightly understood,)

His life he to his doctrine brought, And in a garden's shade that sovereign pleasure sought.

Abraham Cowley

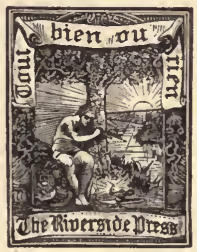

BOSTON AND NEW YORK HOUGHTON, MIFFLIN AND COMPANY rebe Itmergioe presig, Cambrioge 1892 


\section{Copyright, 1892 , \\ BY MARY CAROLINE ROBBINS.}

All rights reserved.

The Riverside Press, Cambridge, Mass., U. S. A. Electrotyped and Printed by H. O. Houghton \& Company. 


\section{To J. H. R.}

\section{Denicate}

THESE RECORDS OF OUR HAPPY YRARS

OF WORK AND HOPE. 



\section{CONTENTS}

PAGR

Introduction . . . . . . . . . . . . . . vii

I. The Old Place . . . . . . . . . . I

II. Planting Willows and Pines . . . . II

III. A Baby Forest . . . . . . . . . . 23

IV. Clearing Up . . . . . . . . . 35

V. On the Perversity of Certain Trees . . . $5 \mathrm{I}$

VI. The Wreck of an Ancient Garden . . . 63

VII. A New Perennial Garden . . . . . 75

VIII. A Venerable Orchard . . . . . . 85

IX. A Struggle with the Web-worm . . . 97

X. Planting Trees on a Lawn . . . . . . I11

XI. Reclaiming a Salt Meadow . . . . . 123

XII. Terraces and Shrubs . . . . . . . 137

XIII. Evergreens in Spring . . . . . . I5I

XIV. The Love of Flowers in America . . . 165

XV. The Rose-Chafer . . . . . . . 177

XVI. Sufferings from Drought . . . . . . I9I

XVII. The Blessing of the Rain . . . . . 203

XVIII. Discouragements . . . . . . . 215

XIX. A Water Garden . . . . . . . 229

XX. Landscape Gardening. . . . . . . 245

XXI. The Waning Year and its Suggestions . . 26I

XXII. Utility versus Beauty . . . . . . 277 


\section{INTRODUCTION}

These chapters, which originally appeared in Garden and Forest, were written partly to acknowledge $a_{\text {. debt for many }}$ practical suggestions derived from its pages, wbich belped us in our efforts to bring barmony and beauty out of neglect and desolation in one of the "abandoned farms" of Massachusetts; and at the same time to show the pleasure and interest we found in endeavoring to create a garden and forest of our own.

The experiments that I relate are by no means completed, and the mistakes made will call for sympathy, as the successes will claim congratulations; but to those who will kindly go with me along the way we bave come, at all events the story ought to show what can be done with moderate expense, by the aid of sucb excellent publications as are now within vii 


\section{Introduction}

reacb of every one, and bow, by loving labor, the old may be made to add charm and dignity to the new, while the new lends purpose and meaning to the old. What bas given so mucb delight in doing, must, it seems to me, give pleasure when told, and it is in this bope that I venture to detail our very simple experience.

M. C. $R$.

Overlea, October 8, 1891. 
I

THE OLD PLACE 
In a coign of the cliff between lowland and highland,

At the sea-down's edge between windward and lee,

Walled round with rocks as an inland island,

The ghost of a garden fronts the sea.

A girdle of brushwood and thorn encloses

The steep square slope of the blossomless bed

Where the weeds that grew green from the graves of its roses

Now lie dead.

SWINBURNE. 


\section{I}

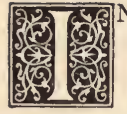

the very heart of old New old houses England towns there may often England. be seen some dilapidated house falling into ruins, surrounded by half-dead fruit-trees and straggling shrubs, while an adjacent garden, once productive and blooming, runs to waste beside it. Its gates are off the hinges, the fences falling to pieces, the hedges untrimmed, the flower-beds smothered in weeds; coarse burdocks and rampant wild vines encumber the ground and run over into the highway, the trim paths have disappeared, the out-houses are toppling over : forlornness and abandonment speak in every line of the decaying house, the former gentility of which renders its decline still more melancholy.

It was such a dreary old place as this that attracted our attention when we first came to settle in Massachusetts. Why 


\section{The Rescue of an Old Place}

such a desirable spot should have fallen into disrepute was always a surprise, for the situation in itself was excellent, the estate running for nine hundred feet along the main street of the town, and lying about half way between the two villages known in popular parlance as The Plain and Broad Bridge, so that it was only a quarter of a mile from the post-office of one, while the railway station of the other was within a ten minutes' moderate walk for a man. Moreover, it commanded a lovely inland view, and had an unusual variety of surface to make it interesting, as well as a fertile soil for grass and garden.

The view was what particularly appealed to us, for it comprised a charming stretch of salt meadow, with a blue stream winding through it like a ribbon, skirted by low, heavily wooded hills, with a distant glimpse of houses overtopped by the masts of the shipping in the harbor. From the higher levels of the farm one could catch a glimpse, when the leaves were off the trees, of a strip of blue sea, and Boston Light could plainly be seen 


\section{The Old Place}

revolving after sundown, while of a still evening the monotonous roll of the waves upon the beach could be clearly heard.

The old house, which we vainly tried to find habitable, had stood for two hundred The ruined house. years, and must have been a fine dwelling in its day; its rooms, though low-ceiled, being spacious and numerous, and their outlook picturesque. It was ill-planned for modern ideas, though many of its contemporaries in this ancient town are still occupied, and by a little alteration made very comfortable; while, owing to neglect and ill usage by tenants, the owners having long since moved away, it was in a condition of hopeless disrepair. The floors had settled, and the walls with them, until in some of the lower rooms there were gaps beside the beams of the ceiling, in which rats or squirrels had made their nests, so that supplies of nuts were to be seen safely stored away in the holes. The window-panes were broken, the shingles mossgrown and ragged, the chimneys falling into ruins, and the sills had rotted away. Moreover, the road that wound by the door had been so raised by the accre- 


\section{The Rescue of an Old Place}

tion of two hundred years, that the part of the place around the house lay in a hollow, and, there being no one to complain, the town dug water-ways and coolly drained the road over the surface of the ground, so that, after a spring freshet, piles of sand were to be found all over the grass, giving the farm a water-logged aspect that added to its disrepute.

We buy the

From this, and from the fact that, situated as it was between the two villages, it formed absolutely a part of neither of them - to us an advantage rather than a drawback, but to the town's-people an objection - it resulted that when the farm was put up at auction, some ten years ago, no purchaser could be found at any price. Finally, convinced that the land was worth more without the house than with it, the owner took it down, and, to the great amusement and consternation of the old farmers, who despised the spot, we bought the place for a moderate sum, having convinced ourselves by careful examination that it would at least give us an occupation for the rest of our natural lives to get it into condition; and as that was what 


\section{The Old Place}

one of us wanted, we were disposed to try what could be made of it, and confound " our critics.

Then arose in the village a murmur of disapprobation and superior wisdom, such as is apt to follow any purchase in a New England country town.

"What does the doctor want of that forlorn old hole? Only a salt-ma'sh to look at, neighbors. and the road a-drainin' right into it all the time. Ain't no place to put a house; too shady and wet where the old one was, and ef he goes up on the hill he 'll jest blow away. Used to be a good farm in the old man's time ; best garden spot in town, but pretty well run out now ; and the fences! It 'll take all he 'll earn to keep them fences in repair; half a mile o' fencin' ef there 's a rod."

And so the croaking went on behind our backs, and sometimes to our faces, with only a word of good-will now and then from people who recalled the charm of the old place when it was in the hands of the family, and hoped that something of it might in time be restored.

We ourselves, left face to face with our 


\section{The Rescue of an Old Place}

bargain, went over the land, now our own, and took heart of grace as we planned our first improvements, and decided on a site for the house. When we took an account of stock, this is what we found : -

A queershaped lot.

A curiously shaped piece of land, something like the State of Maryland, omitting the Eastern Shore. The long front of about nine hundred feet, lying upon the main street, at its southern end was nearly six hundred feet in depth; but this part of the place was a barren gravelly hill, which had been pastured until nothing was to be found upon it but a thin, wiry grass, full of white-weed and a growth of short briers. In the autumn it was a blaze of Goldenrod. The hill sloped steeply to the north and northeast, so that the side of it was exposed and cold, the wind sweeping up across the meadow from the sea in bleakest gusts. This we at once determined was the place to plant Pines, with a view to a subsequent forest. At the foot of the hill was a fertile swale of excellent grass land, which intervened between it and a second rise of land, which was the termination of another gravelly hill, through 
which the main street had been cut, leaving upon our side a small knoll, from which the ground sloped in every direction, making a perfectly drained and slightly elevated spot for a house, an excellent, but rather limited situation, perfectly barren of trees and requiring much grading.

On the north side of this knoll was another abrupt slope, and then the ground swept on below the level of the highway, gradually narrowing, as a back street, running obliquely, came to intersect the main road at the northern extremity of the place, where was an Apple orchard of immense old trees whose bending boughs swept the ground; and in the very point a wilderness of Locusts and Wild Cherries.

The site of the old house, shaded by The old site some fine Elms and White Ashes, was too not availnear both streets to be at all desirable, able for $a$ new house. though the shrubbery and the tangled remains of an old flower-garden rendered it very attractive; but at the rear the saltmarsh was in too close proximity, and about half an acre bordering on the back street was so overflowed at times by salt 


\section{The Rescue of an Old Place}

water that it would only afford a crop of marsh-grass.

The neighborhood of this meadow was thought to be one of the drawbacks of the spot by many; but knowing that it was perfectly wholesome, and certainly beautiful, to us it was only an added advantage, so long as the gravelly knoll gave us so good a foundation for our dwelling.

A fence of

Our first problem, the fences, we determined to deal with by planting Willows. The barren hillside was to be screened with Pines, and procuring and setting these was our first subject for consideration. 
II

PLANTING WILLOWS AND PINES 
"Willow! in thy breezy moan

I can hear a deeper tone;

Through thy leaves come whispering low Faint sweet songs of long ago -

Willow, sighing willow!"

Mrs. Hemans.

"Who liveth by the ragged pine, Foundeth an heroic line."

EMERSON. 


\section{II}

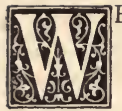

HEN one has nearly half a mile of boundary to define around his four-acre lot, the question
arises how it can be inclosed his four-acre lot, the question
arises how it can be inclosed On the inclosing of grounds. with the least expense and trouble, and in such a way as not to disfigure the grounds. With this problem we had now to deal.

The front upon the main street, thanks to the sociable fashion of our day, it would be quite proper to leave open, with only such screen of shrubs and trees as we should decide upon when the house was built, and the lawn properly graded. Part of it was already well hedged in with ancient bushes, which straggled about where the old house stood, in most admired disorder. But all along Winter Street, as the road behind us is somewhat ambitiously designated, the fence was tumbling down, and the whole garden spot lay uncomfortably open to view, as well as to the cold 


\section{The Rescue of an Old Place}

We decide east winds that blow across the meadow to plant willows.

from the sea. We decided that here a row of Willows would come in admirably, as there would be plenty of rich moist soil for the young trees to root in, and with such a protection the wind-swept garden would in time be warm and secluded, while the silvery foliage would be a harmonious setting for the emerald meadow and the sapphire stream.

This idea we carried out the week after we made our purchase. A friendly farmer neighbor, compassionating our folly in starting such an enterprise, but anxious to see what we would make out of the place, kindly offered to give us as many cuttings as we wanted; so one bright day in June he appeared upon the scene with a cartload of Willows, a crowbar, and a hatchet, and, with a man or two to help him, before night he had cut and driven firmly into holes, easily punched by the crowbar in the soft soil, some five hundred bare stakes, every one of which in a few weeks put forth a crop of roots and leaves.

The stakes, sharpened at the end, were about three feet in length, one foot of 


\section{Planting Willows and Pines}

which was driven into the ground, and How we did firmly stamped into place. It was found it. better, in driving them, to have them set at an angle of about twenty degrees, with the tops pointing toward the south, so that the stems did not receive the full force of the midday and afternoon sun. We used the common White Willow (Salix alba), which abounds along swampy roadsides everywhere in New England.

These trees have all thriven well, though owing to the marsh being salter in certain places than in others, some have grown less rapidly than their companions. The fear of the salt water led us into the error of planting one row of trees at first inside the fence, and at some distance from it, where the presence of Clover and English Grass showed that the top soil was fresh. Subsequently, when they were all well rooted, we removed them to the outside along the highway, where they now begin to make an agreeable shade and an effective screen. The annual dumpings of sand made by the town along the edge of the road, to maintain its level, which constantly tends to sink into the marsh across 
which it has been carefully built, seem to help the trees, which continue to send out surface-roots as the ground rises about them; and though some of them during their first seasons had a sorry time of it in dry, hot weather, they ultimately pulled through, and are no longer sources of anxiety.

The barren hillside.

The most exposed portion of the place being thus provided for, we turned our attention to the barren hillside, which was a pretty hopeless-looking spot for trees of any kind. This elevation, some forty feet high and running back nearly six hundred feet from the main street, seems to be the bank of some former water-way; at least I like to fancy that the odd terraces, which break its otherwise even slope, represent the gradual subsidence of some body of water which must once have filled the gorge, when the present meadow was an arm of the sea. Gravel and sand, mixed with moderate-sized cobblestones, are its constituent parts, nothing like a boulder having come so far down. We have often regretted that some of the noble rocks which abound on the other side 


\section{Planting Willows and Pines}

of the street, farther up the former stream, were not on our hill to form a feature in our landscape-gardening, marked as they are with the scratches which show the grinding of some primeval glacier.

Over the rough foundation of our hill a character thin soil has formed itself; fairly deep on of the soil. the level top where the plain begins, but constantly washed off down the sides into the swale below. It seems hardly possible that trees can ever have grown here, nor are there the smallest traces of any in or upon the soil; but here we resolved that trees should grow; and again the farmers mocked at such a wild idea, and looked forward with sombre satisfaction to our discomfiture.

But how to set about it?

To plow the surface, unless we could $A$ harmiess yoke a goat to the plow, seemed impossitumble.

ble, since we had just seen a man and a horse and a dump-cart roll together, in a confused but unharmed heap, from the top to the bottom, on account of an incautious step off the level. Even if we could have plowed the ungrateful soil, of what use would it have been, since there was 


\section{The Rescue of an Old Place}

nothing to bring to the surface but stones? Cultivation being apparently out of the question, the trees would have to take their chance, and a wretched chance, too, for the south shore of Massachusetts Bay is subject to long and severe droughts, and to several months of hot weather in the summer.

$A$ north slope good

But here we were upheld by our authorfor Pines.

ities. An excellent book on forestry gave us some consoling statistics, and later, our favorite horticultural journal was invaluable in its suggestions. We found that in reforesting hills in France and Switzerland

- that had been swept bare by avalanches, a northeast slope proved the most favorable exposure for the growth of young Pines, and, if we had nothing else, we had plenty of north and east, with the winds thrown in; so, if that was the sort of thing that they liked, why, bring on the Pines, and let them have all they want of it.

But by the time we got round to this job, as the farmers say, the season for spring planting of Pines was over, and an exceptionally dry and burning summer was in full blast, and the very grass on the hill 


\section{Planting Willows and Pines}

was crisped and dry. Our impatience, however, was too great to permit us to wait for another year to begin our experiment. We had read some accounts of August planting of Pines, and determined to have our little fling on the spot, and find out for ourselves whether it was a good time or not.

So we waited, as anxiously as the pro- We hunt phet Elijah, for the first sign of rain, and for trees. when at last the brassy heavens veiled themselves in cloud about the middle of August, we started off after trees - not the pampered darlings of a nursery, used to water and rich soil, but the hardy roadside denizens of dry pastures and sandhills. We picked out the driest and sandiest spots to dig them from, so that if their roots discovered nothing to feed upon in their new locality, they would, from long habit, have got used to short commons, and could adapt themselves to the situation.

Before going out we had the men dig holes over the surface of the side hill with a grub-hoe, banking up the thin soil at the lower sidc of the holes with sods, so as to make little dams to retain the water; in 


\section{The Rescue of an Old Place}

We plant them.

these holes we set the trees we selected, which were not over three feet high, but stocky and well rooted. When possible we took up the dirt with them, keeping their roots moist, and well shaded in the cart, and no more were brought at a time than could be set in two or three hours. After they were all planted, with great labor and trouble, we gave our nursery a thorough watering, and then, except on two or three subsequent occasions, when things looked really desperate from drought, they were left to take their chance. Luckily that year the rains began to fall soon after they were set, and the autumn was a very wet one, so that a good many of the little trees were living in the spring; but another batch, set in the latter part of May the following year, owing possibly to the very heavy rains of 1888 and 1889 , did so much better, that we shall always be disposed to give the preference to spring planting in the future.

Of some one hundred and fifty Pines set upon this barren northerly hillside, under these cruel conditions, about eighty sur- 


\section{Planting Willows and Pines}

vive, a few of which are still leading a precarious existence, while the greater part are flourishing bravely, making a fine show in winter against the snow. In summer they shade so completely into the unkempt green background of the hill that, unless seen in profile, they are barely visible, even when five feet high, and very bushy. Still farther back we have tried setting out very small Pines, and have sown the ground in autumn with countless Pine-seeds, and nuts of all sorts, which come up satisfactorily enough, and do bravely for a month or two, but suffer dreadfully in July and August. They are a fruitful source of anxiety and disappointment, because they cannot make up their minds whether to live or die. The young Oaks are especially trying in this respect, for when we have fairly given them up for lost, they thrust out a feeble little leaf and make a fresh effort at existence, but at this rate a millennium will be too short for them to get their growth in. I have read somewhere that an Oak grew from an acorn in this commonwealth of Massachusetts, forty feet in fourteen years, but if these hillside 


\section{The Rescue of an Old Place}

acorns achieve fourteen feet in forty years we shall feel we have not lived in vain. "What do you do to make trees grow?" trees grow.

I asked an Englishman who was coaxing along a rebellious Butternut to some show of vigor.

"Oh!" said he, "I just talks to 'em, and tells 'em to grow, and they grow."

Mindful of this advice, I do not fail to exhort these recreant acorns, but no teacher of a primary school ever had a worse time in getting a shoot out of a young idea, than do I out of this infant class of refractory nuts and seeds. 
III

A BABY FOREST 
The seed has started, who can stay it? See, The leaves are sprouting high above the ground. Already o'er the flowers its head; the tree That rose beside it, and that on it frowned, Behold! is but a small bush by its side. Still on 1 it cannot stop; its branches spread; It looks o'er all the earth in giant pride.

JONES VERY. 


\section{III}

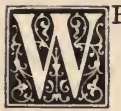

E know that mothers love best those children who give them hill. the most trouble, and it must be on some such principle that this barren hillside of ours wins our best affections ; for, as we cultivate its seemingly thankless surface, while it disappoints and resists our loving efforts, all the more there grows in us a tender comprehension of its hidden beauty, a wider sense of its possibilities, and a greater patience with the slow processes by which it is to be restored to vigor and productiveness.

We sympathize with its struggle for selfadornment, poor, barren, ugly thing. The cold northern slope comes slowly to life, turned away as it lies from the fostering sunlight. When the plain and swale are bright with the hues of spring, the uncut grass upon its side is still brown and withered; it seems to dread awakening from 
its winter sleep, but at last it begins to star itself over with blossoms of white Saxifrage, and anon it grows purple with Bird's-foot Violets, sending out in the sunshine that soft, fleeting perfume which is a hint of the riper fragrance of their English cousins.

The flowers that seek to adorn it.
At this season, too, the exquisite wild Columbine decks it with earrings of coral and gold, which the country children call meeting-houses from their steeple-shaped horns, and over it the all-pervading Daisy waves its white and yellow blossoms sturdily in the wind, while the wild briers put forth their roses, and the Dog's-bane its fragrant cymes, till the Goldenrods and Asters come at last to hide its barrenness with their royal splendor. And all the while there are short, thin grasses, of tender greens and browns, clothing it humbly, while spots of vivid emerald moss indicate the presence of hidden rivulets that feed a living spring that lies at its foot.

In this spring is the possibility of a water garden, of which there is already a beginning. All summer long you can see shining there the blue eyes of great For. 26 
get-me-nots, the seeds of whose forefathers Forget-mewere brought, long ago, from stately Fon- France. tainebleau by a gentle artist, who planted them by his own brookside, whence they have overrun and made famous the Hingham Meadows, their bright blossoms, like scattered fragments of the sky, gleaming among the rushes, and affording a valuable industry to the small boys who sell them at the railway station as you pass. In addition to these continuously blooming flowers, there are Pussy Willows and white Violets in the spring, and in the late summer the Arrowhead lifts its sculpturesque blossom and fine outlined leaf from the water, and the Cardinal-flower uprears its scarlet spikes amid the blossoms of stately grasses. Some day we hope to see a Pond Lily asleep upon its surface, and if the Lotus-flower would but brook our rigorous winters, we should add one to the collection.

At the foot of the hill, at each end, is a stray la clump of White Birches, ladies of the dies. woods that have strayed from their home, and lost themselves on this waste, and rustle their thin leaves timorously, bend- 


\section{The Rescue of an Old Place}

ing their slender white stems as the seablasts strike them. Now that we have stopped mowing and pasturing, we find clumps of Bayberry and Chokecherry bushes coming up under the tumble-down old rail-fences between us and our neighbors, so that these last are already high enough to shade the boys when, tired and hot with play, they throw themselves upon the ground under their grateful protection. $A$ tennis
court on the For on the summit of the hill there is level hill. space enough, inside our line, for a tenniscourt, from which you can look for a mile across the meadow to the tree-clad hills beyond, and the clustered houses and masts of the harbor, half-buried in trees, and seek for the blue line upon the high horizon that indicates the sea.

Straggling paths, worn by careless feet, lead up the hillside in those pleasant, meandering ways that indicate the foot of man, and, in imagination, we see them shaded by the Birches and Pines that we have hopefully planted along the borders; for, in moving our trees with the surrounding sod, we usually brought along these close companions; the Pines and Birches 28 


\section{A Baby Forest}

being so married, in most instances, that it seemed a cruelty to separate them.

Hope and faith are qualities that find splendid exercise in tree-planting, and no pursuit can be more unselfish; for, as we watch the tardy growth of our plantations, it is with the stern conviction that other eyes than ours will see the waving of treetops above them, and that far younger feet will tread the fragrant woodland ways when they are at last carpeted with Pineneedles. It is by this spirit that we become one with Nature, sharing humbly in her patience, in her vast unending plans, The patience of Nature. in her bountiful provision for the future. What better boon to the race can a man leave than a wood that he has planted, in which a future generation may walk and bless his name? Or, if the name be forgotten, there shall abide the forest-blessing, ever beneficent, the mother of springs that fertilize the plain, a shelter to the weary, a delight of the eye, a source alike of profit and pleasure while it endures.

We have friends who scoff when we take them to walk in our forest and beg them not to step on the Oaks; but, to us, 
these tiny seedlings, so feeble and unimportant, are personalities that we have cherished through successive seasons, feeding them when hungry, giving drink The suffer- when dry, grieving when their tender ings of the
young oaks. leaves, scorched by too fierce a sun, withered and fell, and rejoicing when, under the cool rains of September, their little bare stems put forth fresh crowns of leafbuds. Much comfort can be taken in the fact that an Oak once rooted will not wholly perish, but some day conquer even the most obdurate of soils. Like good seed sown in the heart of a child, the storms and sunshine of the world may seem for a time to wither the plant to the ground, but in the end the beauty and power of deep-rooted character will prevail and bear fruit.

We have in our experiments endeavored to make use of such materials as lay at hand, though well aware that nurseries and gardens could have helped us on our way more rapidly. But trees, if purchased, are expensive luxuries, and our object has been partly to see what can be done without much money, and with only a moder- 
ate amount of labor. Our experience has shown us, what the books on forestry told us in the beginning, that sowing seeds Transplant. ing more sat isfactory than sowing. and nuts is far less satisfactory than transplanting small trees; but we have had the entertainment of proving their statements for ourselves, and find our compensation in such trifling results as we have achieved. The Pine seeds, which we shook from the cones in the autumn, and planted before they had time to dry, came up profusely enough in little clusters, but so tiny and weak, that it is wonderful that they are ever discovered even in the thin grass of the hillside, which we leave near them to afford shade. They make, under these conditions, a sturdy little growth so long as the weather is cool and moist, but are apt to disappear altogether in the month of July. Any small tree, that one can pull up by a wayside, will make better returns for a little attention than these slowgrowing mites from seeds.

Such White Birch seed as we have sown, either because we did not know when to gather it, or whether it came from the wrong tree, has failed to come up at all; 


\section{The Rescue of an Old Place}

but in the sandiest and most uncomfortable part of the hill we find little seedlings that have come up of themselves from the trees at the foot, so that we are fain to confess that Nature understands her business better than we do.

Experience with nuts and seeds.

The very small Pines, a few inches high, of which we have set a large number on the rear of the hill, do not grow as well as the larger ones, and are more apt to die. So far our experience leads us to prefer good-sized trees of all kinds for transplanting, rather than small ones, the larger tree seeming to have more vitality to come and go upon until new roots are formed, and it has become adapted to its new conditions.

We have planted various kinds of acorns in great profusion, but the Mossy-cup and the Chestnut Oak seem to thrive best in this waterless soil. The White and Red Oaks seem to require enriching to hold their own at all, and Maple seedlings, which come up promptly, yield to the first drought, though very small transplanted trees live on. Hickories, though slow in growth, are not vanquished by the con- 
ditions, and little yearling Chestnuts, transplanted and dug about, flourish bravely.

From a friend in town, whose English Planting Walnut-tree has borne profusely after the Walnuts. recent warm winters, we have obtained fresh nuts, which, promptly set, have germinated and given us fine little shoots in one season. This tree is a more rapid grower than any of our native nut-trees, and so far has stood the winters, but we have had no weather below zero here since 1887 , and cannot answer for the effect of an old-fashioned season. The fieldmice have a great predilection for them, and gnawed our largest one down to the root a year ago, but it came up again in the spring with redoubled vigor, and made up for lost time.

Small Black Birches, dug up by the Resuliss roadside, and put into holes prepared for them in the side of the hill, have thriven without much attention, and make a favorable growth; but some Ailanthus-trees from a nursery, in spite of Horace Greeley, have refused to do anything at all. In the swale at the foot of the hill, where the soil is deep and moist, all trees flourish. 


\section{The Rescue of an Old Place}

English Oaks grow rapidly from acorns, and we have a fine group of Chestnuts, transplanted when fifteen feet high, that grow well after being cut back sternly when set. Though much beset by insects, they are now firmly established, having been planted in the autumn of 1888 . In this same moist, rich soil we have also had very good success with that difficult tree to move, the Hemlock; and the Tulip-tree and the Mulberry also flourish, though the tender young branches of the latter suffered after the last two warm winters, dying back badly.

Climbing the hill e.tpands the lungs.

To get all this young family started, as may be imagined, took a great deal of time, and much subsequent attention, one favorable result of which is that from constant clambering up the steep hill, which was at first a breathless piece of business, our lungs have developed to such a degree that we are disposed to recommend the cultivation of a forest on a slope to all such as, like Hamlet, are "fat and scant of breath," for the fine stimulus it proves to the action of the heart. 
IV

CLEARING UP 
The dense hard passage is blind and stifled, That crawls by a track none turn to climb To the strait waste place that the years have rifled

Of all but the thorns that are touched not of Time;

The thorns he spares when the rose is taken; The rocks are left when he wastes the plain; The wind that wanders, the weeds wind-shaken, These remain.

SWINBURNE. 


\section{IV}

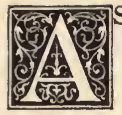

"trees will grow while one sleeps," according to the old adage, we made planting our first business, and left setting the place in order to come later, for it seemed to promise an, indefinite job, everything having gone more or less to rack and ruin during its period of abandonment and desolation.

The forlornness of an old, neglected $A$ forlorn farm is largely owing to the condition of its trees and shrubs, which, being left to themselves, take on a tumble-down, halfdead look that often belies their real condition. A few decayed trees bring all the others into disrepute, like a grog-shop in an otherwise respectable neighborhood, and untrimmed shrubs are as unbecoming as unkempt hair.

When we came to examine matters at Overlea, as we named our acquisition, from 
its command of the meadow, we found that a good sweeping and dusting would do wonders for it, and with that enthusiasm for setting to rights inborn in the New England breast, we prepared for a grand redding up.

While the grading of the knoll was going on preparatory to building the house, our factotum, appropriately named Blossom, since his function was to adorn the place, was busily employed in removing all the unsightly dead limbs from among the live ones, and in hewing down such old Pear and Apple trunks as proved hopeless.

The logs and branches were dragged away to the wettest place in the meadow at the back of the knoll, and transformed into a corduroy road, by which one could pass dry-shod out into the rear street. This floating rubbish, supported by the tangled grass on the marsh, formed a foundation upon which, after inserting a plank water-way at the bottom, for the $\mathrm{ebb}$ and flow of the tide, we subsequently built a substantial carriage-road of stones 
and gravel, which now affords a back entrance to the stable and kitchens.

The palings of the fence were removed for kindlings, but the posts and rails were left to form a slight boundary until the hedges and tree rows should be fairly established; the straggling shrubs were trimmed into better shape, the Box-arbor clipped and cleared of weeds, trailing vines were taught once more the use of a trellis, and the grass was mown and raked clean of the last year's rowan.

Fierce war was made upon the Bur-We dobat. dock and Mint and Horse-radish that had weeds. squatted everywhere on the land; load after load of the accumulated rubbish of years was buried under the corduroy road, and hidden from view with gravel; the Pear-trees were carefully pruned and tied up, and the old Grape trellis stiffened with new posts and lattices.

When all this was done, and it was no brief job, the place took on a civilized air truly surprising, but, like the boy's washing his face, which cost his father a thousand dollars, the felling of the first ragged 


\section{The Rescue of an Old Place}

old tree was an entering wedge of improvements that found no end.

The clearing up revealed unsuspected beauties and possibilities in the old place, and at the end of it we had taken an account of stock, and were aware that we had become owners of a treasure-house of enjoyments. But the charms and wealth of that old garden are " another story," which remains to be told later.

Grading the knoll.

While all this spring and fall cleaning was going on, the heavy labor of grading was in progress. Teams and men were coming and going, heavy scrapers were plowing part of the little knoll down into the valley, and loads of gravel were being dumped to bring the slopes into proper form, the surface soil having been first removed to cover the future lawn. Week by week the work went on, till the very landscape changed its contours, as the removal of the crown of the knoll threw open to view, from the sidewalk, the fine stretch of green meadow and blue stream, once hidden from view by its cone.

When our much interested critics found that we had chosen the site for our dwell- 
ing in an unexpected part of the grounds, their murmurs again reached our ears. "Why in the world don't the doctor Advicefrom build up on top of the hill, where he can see everything, and be among neighbors ?" sang half the chorus.

- "If I had a lot of big trees like those Elums I'd get the good of 'em, and put my new house on the old cellar," echoed the antiphonal.

"Never can make anything better'n a Shumack-bush grow in that gravel-pit," shouted they all together.

"Well, perhaps he knows what he 's about," would interpose some friendly voice ; " but it would n't be my way, anyhow. He 'll find out, come to plantin', that he's got to have soil, even for a dooryard."

When it came to building the foundations, their distance from the highway seemed inordinate to most of these critics, but now and then we were reproached by the more ambitious for not leaving front enough. In fine, we came to be in full sympathy with the Old Man and His Ass of the fable; but being luckier than he in 


\section{The Rescue of an Old Place}

having a mind of our own, we did not end by pitching house and all into the water, as we might have been tempted to do from the multitude of counselors, in which, in spite of Solomon, there is not always wisdom.

Our firm conviction was that the hill, in spite of the commanding view toward the north, was too bleak and exposed a position to be pleasant for an all-theyear-round home; it was also too near the neighbors' lines, and too remote from orchard and garden.

Conversion of the critics.

On the other hand, tempting as the great Elms certainly were on a hot summer day, the lot at that end of the farm was quite too narrow for a house and stable such as we required. The knoll, though limited in area, gave us plenty of elbow-room, and from its elevation we overlooked the grassy swale on one side, with the hill for a background, and northward could view the ever-changing tints of the meadow, behind the gardens and the fruittrees. Experience has confirmed the wisdom of our choice, and, in justice to our advisers, I will say that they now hand- 
somely admit that, though they "did n't think much of the doctor's ch'ice, to begin with," they are now convinced that "he has got about the likeliest lot on the street."

People question us about our Willows, Are the wiland ask whether we are to make a hedge of lows to be in them or allow them to grow up into trees. "If you allow the Willow-trees to grow up," they ask, "won't they shut off all your view? and if you don't allow them to, won't the labor and trouble of cutting them back every year be serious?"

We do mean to let them grow into trees at their own sweet will, at least for the present. The knoll is so high, and the slope of the ground, from the foot of it to the edge of the place, so decided, that our veranda-floor is some twenty-five feet above the level where the Willows are set, so that they can grow for some years to come without becoming an annoyance. They are also quite a long distance away, as the line runs diagonally between us and the meadow. Should they ever become a serious obstruction, polling once in five years, we think, will keep them where we 


\section{The Rescue of an Old Place}

want them, as from our elevation we can look directly over the top of a very tall old Apple-tree which stands at the foot of the slope near the house, and a Willow in the distance will have to be quite a tree to be really troublesome. A vista cut here and there in the line will really enhance the charm of the prospect, but at present they are not more than fifteen feet high.

Another inquiry has been made with regard to the preparation of the soil on the hill for the Pines.

The Pilgrim Fa-

Unfortunately, we did nothing in the thers of our forest. way of making a bed for them beyond the process I have described. No doubt, they would have fared much better for a little feeding, and more of them would have lived, but the hill was very steep and hard to get at, even with a wheelbarrow; and, besides, we had no soil to spare, for we needed everything we could get for the lawn, and did not care to buy any for so doubtful an enterprise. We therefore tried our experiment under the sternest conditions. However, those tiny Pilgrim Fathers of the future forest stood the trial like little men. Some of them, it is true, 


\section{Clearing Up}

died of consumption, and some of fever; but the survivors are growing tall and stout on their poor pickings, and will do us credit yet.

There is one of them, nicknamed Epis- The history copus, from its birthplace in the church of Episcalot, which is a beautiful illustration of that fable called Nature and Education, in "Evenings at Home," a book which was the delight of the childhood of a previous generation, and an infinite bore to the present advanced infant.

I spied the poor thing one day hanging by one root to the side of a sandhill, which was being graded to a smooth slope, and asked the men who were working there to let me have it. Though much ridiculed for its shapeless and unpromising aspect, it was given a comfortable shelf pretty well down on the slope, and coaxed to hold its head up by various devices. Unused to kind treatment, this wayside waif, which had got used to growing nearly upside down, hung its head and sidled up against the hill, and seemed to find its branches as much in its way as the legs and arms of a guttersnipe in a parlor; but 


\section{The Rescue of an Old Place}

time and training, and the neighborhood of Boston have their influence even on a Pine, and that clerical tree is now a very Bishop in erectness and dignity, having been lopped and pruned and tied to stakes, till it puts the most symmetrical of the other Pines to shame by the vigor of its development, proving that if anything can "beat Nature" it is Education.

The consolation of having a limited number of trees is that each one acquires an individuality, and their owner gets to know them as a shepherd does his flock. I wish every one could learn the way in which these little growing things take hold of one's interest, and people life in the country, and that this pursuit could be taught to children as a branch of their education.

The planting of trees by schools and colleges.

It is the custom in some of our highschools for the graduating class to plant a tree in the neighborhood of the schoolhouse and for a long period it has been the time-honored custom of universities to set out a vine in commencement week, to commemorate the class that is leaving college. 
During a visit last summer to an eastern town, my attention was called to the Ampelopsis, each vine labeled with the date of the class cut in one of the stones of the foundation of the college chapel, near which the plants were set, and it was melancholy to see how forlorn and small many of them were, and how others had died completely for lack of attention. The same may be said of numbers of the pitiful little Maples and Elms that huddle around the unpicturesque and bare high-school buildings in some parts of New England, which really should by this time be amply shaded if a proper attention had been paid to the young trees when set out.

It strikes me that a radical change should be made in the time of planting A change
should be made. these commemorative trees and vines. Instead of setting them out at the close of its career, every class should on entering the school or university erect its growing monument, and devote its best energies during the four years of school or college life to having its vine or its tree beat the record in growth and vigor. In this way, if one specimen died another 
could be planted, that the class might be sure of a memorial, while yearly a committee should be appointed to attend to the plant, and a small subscription be levied on each member of the class for proper fertilizers and cultivation.

Boys should be taught to take an interest in forestry.
If the personal attention of the boys could be given to the subject, if they would themselves dig about and enrich and prune what they had planted, and would take pride in it, the effect would be good in awakening in their minds an interest in the growth of plants and trees; and some slight knowledge might be acquired of climatic and soil conditions, while a hint might be given to them of one of the best and purest pleasures which is within the grasp of man.

In this way could be instilled into the rising generation an interest in forestry, that might in time bear fruit in greater care for this property of the nation. Among the books of reference in schools some should be supplied which treat of the proper management of growing things, so that the youths and maidens could study the subject for themselves. If, at 48 
the end of each year or four years, some slight reward, such as a simple medal or even an honorable mention, could be awarded to that plant or tree which had made any surprising growth, it might still further stimulate an interest among the young people in this most beautiful and useful work. If masters of schools and professors of colleges would use their influence to bring about this change as speedily as possible, it could not fail to do good to the youths themselves, and would replace with vigorous trees and vines the usually melancholy specimens which many classes now leave behind them as their monument.

The forester of ever so minute a wood The foresthas a fund of enjoyment on his plantation er's enjoythat no unlimited order to the best of landscape gardeners can ever give him. It is a fine spiritual exercise to bring the mind into sympathy with inferior organisms, and when one has fairly learned to love anything so stubborn and irresponsive as a tree, he has gained a step in mental development, even beyond that point won 


\section{The Rescue of an Old Place}

by a sympathetic understanding of his brother man.

$A$ flower garden less interesting than a garden of trees.

However fond one may be of a flower garden, I doubt if it ever yields quite so sturdy a satisfaction as the culture of trees. It is the difference between bringing up a girl and a boy, - one all light, color, sweetness, a thing to be cherished and tenderly sheltered and nurtured; the other less outwardly winning, more obstinate in development, more independent and manly in habit, but more worth while; a thing of positive pecuniary value when well grown; and formed, when symmetry and breadth are fully attained, to be of service in sheltering the weak and weary who seek protection in what Mrs. Gamp would call "this wale." 


$$
\begin{gathered}
\mathrm{V} \\
\text { ON THE PERVERSITY OF } \\
\text { CERTAIN TREES }
\end{gathered}
$$


My wind has turned to bitter north, That was so soft a south before; My sky, that shone so sunny bright, With foggy gloom is clouded o'er. Arthur Hugh Clough. 


\section{V}

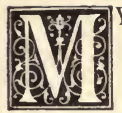

conscience would lead me to Apology dwe make an apology to my treenurslings for having called them stubborn and irresponsive, when they have in many instances given me so much satisfaction; but as I feel that it is necessary to be as honest about mistakes as about successes, in order to render these records truly valuable, I feel it my duty though it is almost as bad as betraying a domestic secret - to admit that they have been a trial. And that people may not be led away into thinking a tree nursery any freer from failings than a child nursery, I must tell the painful as well as the charming facts about them.

No one knows better than I how much some of the more satisfactory among them will do for one under kind treatment, but, The freakishness of some of them. all the same, I must reluctantly maintain that many of them are freakish and dis- 


\section{The Rescue of an Old Place}

appointing ; not, perhaps, so much from their inherent wickedness, as from the baneful influences of the world outside, the flirtations with insects of which they are capable, their predilection for ornamenting themselves with bright colored fungus growths which check their development, a perverseness about living, even when given the very best advantages, only paralleled by those Chinese servants who go and kill themselves if their master speaks sharply to them; and, above all, a stubbornness about adapting themselves to new conditions as great as that of a trueborn Briton.

A tree the

Your tree is the true conservative, and servative, will insist upon its own way quite as unreasonably as a human being, even when you are sure you know what is better for it than it does itself. It is as hard to bring it to a new way of living as it is to bring about a constitutional amendment. If there is a spot where you do not want a tree to grow, notably a garden bed or your potato patch, there it will insist on coming up and making itself at home; but, take up this interloper and put it in a 


\section{On the Perversity of Certain Trees}

proper place, where you want it, and, ten to one, it will sulk and defy you.

One's favorites show in extreme youth but of illa propensity to come in contact with cows' regulated horns and the jackknives of mischievous boys, that is another proof of ill-regulated character. They let their top-buds perish in the most careless way, and put out two leaders instead of one before you know it ; they grow unevenly, they make themselves untidy with absurd little leaves up and down their stems, with a vague idea of keeping the sun off their trunks. One has a constant struggle with evergreens to keep their lower limbs in condition; they always prefer to go barefooted. Indeed, I call one Norway Spruce I know of Sockless Jerry, on account of this very failing.

There is a crying instance of depravity $A$ depraved in a moderate-sized White Ash on our White Ash.

lawn, which ought to be a stately tree by this time, for a neighbor tells us it has been growing there for forty years. Every spring it puts out a magnificent crop of new shoots, and we congratulate ourselves that at last it has really made up its mind to go ahead and reward us for 


\section{The Rescue of an Old Place}

all the digging around and high feeding we have given it; but in late June ominous yellow spots appear upon the leaves, great orange-colored excrescences disfigure the young shoots, and the first thing we know they are all shriveled and dying, and the ground underneath it is strewn with blackened leaves. Later it pulls itself together and gets out a feeble crop of young sprouts, just enough to enable it to hold its own from year to year, but which seem to add almost nothing to its girth, and very little to its height.

Now, can any one tell me what is the proper punishment for that?

Hemlocks are perverse.
Of the perversity of Hemlocks I could write a volume. I knew something of their waywardness in the State of Maine, but even in Massachusetts, where everything is regulated by law, they show no higher sense of duty.

In vain do you coax along a beautiful little tree, carefully raised in a nursery till it has a fine ball of roots, to live and thrive for several seasons; at the end of that time you find it in the spring yellow and brown and bare, with every sign of 


\section{On the Perversity of Certain Trees}

premature decay about it. In a clump they may condescend to grow, or on a hill, but if you don't want a clump, or a hill on the lawn, what then?

Any one who has ever set his affections on a Peach orchard knows something of of other the shameless coquetry of its behavior; and in the course of these chapters I shall be compelled to record instances of misconduct even in the most innocent and carefully brought up trees as well as in the wild and unsophisticated ones. Even the common White Birch, which will live anywhere and everywhere, and thrive on a sandbank, goes and gets itself eaten up with rosebugs the minute we try to utilize it on a lawn. Lombardy Poplars, too, in spite of much specious promising, behave shamefully; and I have known a Catalpa to grow undaunted in an inclosure for twenty years and then succumb in a cowardly way to one cold winter. The fact is, though I am loath to say it, as a class you cannot absolutely depend upon trees, and when you say that - why, you say everything !

I have also something to add concern- 
Concerning ing our grove of Chestnut-trees, that were certain chestnuts. taken from a plantation of trees in our neighborhood, which had been made some years ago, on one of the neglected places hereabout. They had been set out when small, and left to take their chances without cultivation for certainly ten years. How much they had received when very young I cannot say, for their gardener has long since moved away. When we got them they were some three inches in diameter one foot from the ground, and slim and stately, with fairly good roots, but not like those of frequently moved nursery trees. We topped them when they were set in the autumn, and as they did not seem very vigorous, the next year we cut them back very severely, of different lengths, as an experiment. Some of them we left ten feet high, and one of them which had poor roots and looked sickly we cut down to within two feet of the ground.

Last summer they all put out vigorous tops with enormous leaves, but they are much beset by the aphis, which makes havoc with the first growth, and later by 


\section{On the Perversity of Certain Trees}

the insatiable rosechafer; yet, in spite of these drawbacks, they thrive in the rich deep soil of the swale, sheltered by the hill from the sun and the burning southwest winds. They are planted about fifteen feet apart, as we thought they would do better in close company, and they can be trimmed out when they are larger if it seems desirable. Smaller ones are set on the hillside, where they seem to flourish, and some future generation may see our hillside, like those noble slopes of the Connecticut valley, waving with their splendid foliage.

But all these trees give us care and trouble, and much disappointment, like late. everything on which one's heart is set, and then we are always finding out things just too late, for we constantly discover in our reading articles published the day after the fair, which show us how much better we might have done had we had the information a year or two earlier. In fact we have reason to think ourselves among those

Mountainous minds that were awake too soon, Or else their brethren slept too late, 


\section{The Rescue of an Old Place}

for no sooner do we evolve an idea and put it in practice, than at every turn the public press is crammed with views on this very subject which it has never seen fit to express previously. Hinc illa lacrima.

Knowledge would have induced dismay.

Had all that we discovered later in print been within our grasp in the beginning, had modern ideas been fairly abroad, how much easier everything would have been! But, also, how afraid we should have been to undertake anything, having learned thus that we ought never to build without a landscape architect, never to plant without the advice of an experienced landscape gardener, never to suffer from mistakes that could so easily be avoided by proper appeals to a professional! But all this wisdom might as well have come in the next century as just a year too late, and so here we are, with all our blood upon our heads, because we chanced to dig our cellar and make our contract a year or two before a certain eminent dendrological journal was born.

Gifts from kindly friends.
As it was, we went to some scientific neighbors, who had done the same thing we were doing thirty years before with 


\section{On the Perversity of Certain Trees}

very distinguished success; and some of them gave us advice, and others gave us trees, which were even more to the purpose; and they kindly encouraged our efforts, and took an interest in what we were doing that sustained and cheered us on our way.

No one's experience, either in books or Wetry our in real life, proves to be exactly like our own experiown, so that we feel that we have had the benefit of an original experiment. Only time can fully reveal where our mistakes lie, for it alone can show whether we have planted not wisely or too well.

61 



\section{VI}

THE WRECK OF AN ANCIENT GARDEN 
A brave old housel a garden full of bees,

Large dropping poppies, and queen holly. hocks,

With butterflies for crowns, - tree peonies, And pinks and goldilocks.

JEAN INGELOW. 


\section{VI}

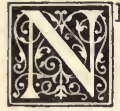

EXT to our tree garden came A wonderthe old-fashioned flower garden as an object of care and interest in the renovation of the place, and here we met with many agreeable surprises; so that we were perpetually reminded of the "Swiss Family Robinson," who, when they went ashore on their desert island, found all they needed to make them comfortable on the wreck, from which, luckily, they were able to help themselves before the old hulk went to pieces. After that, every little thing which was quite indispensable came out of a wonderful bag that belonged to the worthy mother.

Since we landed upon the barren waste of this abandoned farm, we have often had reason to compare the old house-lot with the ship, and the front yard with the mother's bag, for a number of trees and shrubs 


\section{The Rescue of an Old Place}

Miss Betsy and Miss Peggy.

have been forthcoming from the one, while the other has proved an inexhaustible resource, not only for our own, but other people's gardens.

For, once upon a time, in the old house which is now no more, there dwelt two dear old ladies who took great pride in their garden, and stocked it well with all the best flowers of their day, and from it came bulbs and cuttings of roses, and roots of perennials, that still help to make beautiful the ancient gardens of this fine old town. They were women of refinement and learning, much respected and beloved, and the older people still warmly recall Miss Betsy and Miss Peggy, and the days when the old house was always a sunny and cheerful resort. After the place was abandoned and unoccupied for many years, people felt at liberty to come and help themselves to slips of the shrubs and to roots of the old plants, so that one might hardly hope to find anything of value still existing there; but when we came to clear away the rubbish, we were surprised to find what a tenacious hold the occupants had of the soil, so that, as 
the spring and summer months sped by, we were constantly surprised and charmed to find, in unexpected places, some shrub or flower that clung to its old haunts, and, half-hidden from the eye, bloomed away its sweet life heedless of observers.

Along an uneven old wall that had sup- Miss Betsy's ported the terrace of the house, I had a bed dug, into which I transplanted such bulbs and roots as would consent to be torn from their original homes. This bed I call Miss Betsy's Garden, for I am quite sure that in old times that gentle soul must have watched and tended her favorites by this same sunny wall. There is one prim little Columbine which wears a minutely fluted lavender cap that I associate with her, and always call by her name. The flowers that come up in Miss Betsy's Garden are all simple and homely, but to me their quaint familiar faces are more appealing than the far showier and splendid blooms of to-day.

They must have family records of inter- Some highest, these ladylike old blossoms. Those blossoms. yellow Daffodils, with their long green ribbons, have nestled up against that wall 
till, no doubt, they regard it as an ancient castle, of which they are the chatelaines; and $I$ am sure that dignified Narcissus must have a history. There is a sweet A fragrant June Honeysuckle straggling there which breathes an old-time fragrance, and the tiny petals of the pale pink Bridal Rose which flutters beside it have the very tint of soft color one sees in the cheek of an ancient maiden. A wild Clematis seems to grow out of the wall itself, - I have never been able to find its root, - and every fall a Prince's-feather waves its tall plume where once it danced with a Lady's-slipper. The Pansies have all degenerated into Lady's-delights, and the Hollyhocks come up single, but here they grow and blossom beside a pendulous Forsythia, the seed of which was, no doubt, sown by some passing bird, for it is not, I think, one of the older shrubs in this village.

Flowers in the grass.

The rest of the garden is perfectly formless and wild. Nothing has been done to the old part of the farm, except to clean away the weeds and sticks that encumbered it, and the old plants have grown lank and tall along the fence and under 


\section{The Wreck of an Ancient Garden}

the heavy shade of the trees. But here in the spring the ground is blue and fragrant with hardy English Violets, that fill the air with perfume and blossom long before even the native White Violet, which leads the way among our New England flowers; and wherever you walk you come upon a Tulip, or a Star of Bethlehem, or a feeble Crocus choked by the strong grasses, and cheery Daffys are wagging their golden heads in sheltered spots, and later there are to be seen groups of sculpturesque Narcissus shining whitely under the shrubbery, "like a good deed in a naughty world." The Flowering Almond sends up spikes of bloom ; the Periwinkle, white and blue, hides among its shining leaves, while the Moneywort has strayed away from the garden and made of itself a nuisance in the orchard, where it threatens to root out everything else. There also are great clumps of the giant Solomon's Seal in shady nooks, where they grow to wondrous size.

And the Flower o' the Quince is a rare Shrubs in sight in the springtime, as its rosy flush bloom.

mantles the scraggy old trees which are 


\section{The Rescue of an Old Place}

good for little but blossoms. There is a huge Viburnum bush in the orchard which is a snowy mass in May, when the Snowberry buds are showing their little pink heads against the fence, where they struggle with the wild Raspberry bushes which make their life burdensome to them; and in places through the grass, where once a well kept Strawberry patch existed, are to be found the white blossoms of a few survivors mightier than their conquerors.

A clump of

In a low, neglected spot is a clump of those old orange-colored Lilies that used always to abound in country gardens, for once established they could never be rooted out; and these, undiscouraged by frequent mowings, bloom and spread in unchecked luxuriance.

There are Lilacs, purple, white and Persian, in profusion, and the Mock Orange and Spiræas all have their turn as the seasons go round. One White Lilac has shot up to the height of a two-story house, and now that the windows are no longer there to help one to gather them, it shows, when in bloom, a crown of inaccessible blossoms; others yield their wealth of 
The Wreck of an Ancient Garden

flowers nearer at hand, and by the well a Persian Lilac drops like a fountain with rosy jets. No longer supported by the fallen house, Roses of ye

a Trumpet Creeper, which trailed along the ground, has been clipped into a compact bush. A venerable Althæa, which we did our best to save, blossomed feebly for a season or two and then perished, deprived of the accustomed shelter of the porch; but great bushes of the old-fashioned White Rose abound, and there, too, is the sweet Blush Rose, beloved of the bee and the sturdy Hessian. A large Damask Rose still flourishes under the Lilacs, and a luxuriant Baltimore Belle climbs in reckless profusion over its confining wires. Where the fence stood is a low cluster of bushes covered in summer with a bold Red Rose, single and splendid, the remote parent, perhaps, of the Jacqueminot; they call it here the Russian Rose, but I do not know what its real name may be ; and down in the orchard I found a bush of the dear, thorny little Scotch Rose, the smell of which is laden, as is no other, with the memories of childhood. 
There are clumps of Tiger Lilies, and old-fashioned small Bluebells, and Sweet Williams, and a Barberry bush swings its yellow blossoms and red berries over the rear wall ; and under the Box-arbor I found Spiderwort growing in great clusters.

One day, while strolling down along the orchard fence, a familiar odor, heavy and sweet, led me on to where a wild Azalea was hanging out its fragrant blossoms. I do not see why a hedge of these might not do well in this moist soil. I hailed this one with delight as an ornament to the place.

But what we like best is the fine old Box arbor, which has grown up from a garden border until its stout trees are now six inches in diameter, and nearly ten feet high, which shows their great age. They were fair-sized bushes when old men of this town were boys, and to make even a bush of a Box plant is slow work. Here, shaded by a young Elm which has sprung up in the kindly shelter of these twisted old trunks, we sit and look out upon the meadow and the growing plants, and feel 


\section{The Wreck of an Ancient Garden}

linked with the past by this memento of Memento of those who loved this garden spot, and the past. toiled to make it fair and fruitful, even as we, too, toil to restore its beauty and productiveness. 



\section{VII}

A NEW PERENNIAL GARDEN 
Pluck the primroses; pluck the violets; Pluck the daisies, Sing their praises;

Friendship with the flowers some noble thought begets.

EdWARd Youl. 


\section{VII}

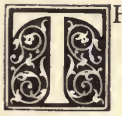

HOUGH the old garden has a It requires quaint attraction from its very $\begin{gathered}\text { gentius to } \\ \text { make the }\end{gathered}$ antiquity, the effort to make its Trossacks antiquity, the effort to make its interesting. successor the subject of a chapter reminds me of the remark of a literary man, who paid his only visit to Scotland in the winter-time, that he realized more fully than ever before how great was the genius of Sir Walter Scott, which had given world-renown for picturesqueness to those low, round, bare, uninteresting hills, the Trossachs. Lacking that genius, I an somewhat dismayed at telling the story of my very unimportant little garden. Our late, cold springs render it rather a dreary object of contemplation even in the month of May, and with only the power of words to help the reader's enjoyment, I shall have to ask indulgence for the meagre record of its very simple charms. 


\section{The Rescue of an Old Place}

An Irish story.

Mrs. Carlyle used to tell a story of an Irish prison that was to be built out of the stones of an old one, while the prisoners were to be kept in the old jail until the new one was completed. This tale suggests our fashion of constructing a new garden out of the former one, and in our case the prisoners showed a decided preference for the original institution, and were with great difficulty persuaded to leave it. We started out with no very definite plan beyond killing two birds with one stone, always a desirable object when one is short-handed, and the results are not particularly impressive.

A garden While the house at Overlea was building, the carpenters kept their tools in a part of the old dwelling that was still standing, and their constant journeys to and fro, between the knoll and the workshop, wore a narrow winding path, along which we had a flower-bed dug, to put such roots in as we wished to bring with us from the rented place that we were occupying, and also to serve as a home for such plants as we might dig up about the 


\section{A New Perennial Garden}

farm. Some sprigs of Box, broken from the arbor, and set in the soil at the edge of the bed, took root and made a rough border, and here, in August, I transplanted Lily bulbs, and a little later put in such perennials as needed to be set out in the fall.

Between this flower-bed and the street Some old were three rows of straggling old PearPear-trees.

trees that gave some suggestion of possible fruitfulness, though it seemed likely that they were too old to profit by pruning. They had been famous in their day, and still preserved the remnants of a reputation, though more modern varieties have borne away the palm in newer gardens. But Bartletts and Sheldons and Seckels will never be out of date, and there are others, the very names of which the old settlers have forgotten, which still yield sweet and luscious fruit, when the weather and the insects permit. Half dead they seemed when we first went to work at them, cutting away the dead branches and scraping their mossy trunks, to the infinite disturbance of the insects which had clustered there for warmth, and we recognized 


\section{The Rescue of an Old Place}

that only strong methods would revive them.

What we did to them.

We needed sods for the terraces we were making, and so began by removing the turf around the trees, leaving narrow strips of grass to walk upon. This furnished us with three wide beds, which we fertilized heavily with rich compost and wood-ashes, the surface being tilled with great care, keeping the edge of the spade turned toward the trunk to avoid cutting off the rootlets of the trees. A memory of an old garden in which I had played when a child, where Pear-trees grew among the flowers, induced me to think of utilizing these broad fertile spaces for perennials. The Pear-trees were at that time doubtful as fruit-producers, but they would afford a grateful shelter from the hot sun when we were working among the plants, and their sparse foliage would hardly interfere greatly with the flowers.

$A$ box of In the spring a generous friend sent me plants. a box of hardy plants, which were set out at random, as they came without labels, and many of them were unfamiliar to me. I do not find that they interfere much 80 


\section{A New Perennial Garden}

with the Pear-trees, which, under this steady cultivation, yield more of their fine old-fashioned fruit than we know what to do with, for pears are a drug in this market and can hardly be given away. The Pear-trees certainly do not hinder the growth of the sturdy perennials, which multiply enormously, so that every spring and fall there are quantities of them to be shared with friends. A nurseryman, who came last year to set some Strawberryplants, declared that, if properly divided, there were roots enough there to stock an acre.

Such strong, showy plants as the Iris, They thrive. the Foxglove, and the Giant Evening Primrose flourish admirably, while Phlox and Hollyhocks and Columbines and Spiræas encumber the ground.

There is a huge Oriental Poppy that is a gorgeous spectacle, with its rich bluegreen velvet robes and its silken headgear of scarlet and black, producing all alone the effect of a procession, as Bret Harte once said of Roscoe Conkling.

Smaller Poppies come up of their own accord, some single, some double, as the $8 \mathrm{I}$ 
Thethings. fancy takes them, and there is a wild arthat grow in garden. ray of Larkspurs and Coreopsis and Sweet Williams all summer. In the spring the variegated Thyme comes up promptly, followed closely by English Daisies and Moss Pinks, and Pansies and Violets, white, blue and yellow. The Giant Solomon's Seal rings its green bells over the heads of the tiny Bellwort; and all summer the Lilies and Peonies and Spiderworts fight for possession of the ground, while the perennial Peas, and Calendulas and Marigolds linger there till the last frost-horn blows.

The collection is not very choice, and, beyond a periodical struggle with the weeds, which try to grow as rampantly as the flowers, it gets not very much attention; but it makes a fine show from the street, and from the veranda which looks down upon it. Any minute effects would be wasted here, and we do not extend its area, which we might readily do, because it already requires more attention than we are willing to spare from the shrubs and trees that we are hurrying along upon the lawn, and which, consequently, take all 


\section{A New Perennial Garden}

our best energies, as well as the lion's share of food. In short, the flower-garden takes what it can get, - copes more or less successfully with its own weeds, and possibly is more satisfactory than if we took more pains with it, and so were liable to disappointments. It is not at all well adapted to annuals, even Mignonettes and Asters, which are sown every year, for the stronger plants rob them of their proper nutriment; but I have future plans for a parterre in that neighborhood, which shall have fitting accommodation for all the sweet old-fashioned kinds of yearly flowers.

Supplemented by the old garden, the $A$ nosegay new will even now at any season afford a had here. fragrant and showy nosegay, such as our grandmothers liked for a beaupot, and there is always a mass of color under the Pear-trees until late in November, when the cold pinches the very last Calendula. The neighborhood of the salt water makes this garden cold, and slow to awake in spring ; but, on the other hand, it modifies the temperature in the autumn, so that it escapes the early frosts, and, under the 83 


\section{The Rescue of an Old Place}

A warm corner.

shelter of the trees, the flowers last long after those upon the high ground about the house have withered and fallen.

There is a sheltered corner, backed by a mass of Lilacs and Mock Oranges, where I dream of seeing some day a fine clump of Rhododendrons and hardy Azaleas, though I have some doubts about a southern exposure being the very best thing for them; but the decorative effect from the house will be so good that we are disposed to make the attempt. Skirting the old wall to the right of this, we come to the ancient Apple and Pear trees which are the remains of the once valuable orchard, that at one time covered a large part of the place. 


\section{VIII}

A VENERABLE ORCHARD 
O blessed shades ! O gentle cool retreat

Fron all the immoderate heat,

In which the frantic world does burn and sweat !

ABRahaM Cowley.

'Neath cloistered boughs, each floral bell that swingeth,

And tolls its perfume on the passing air,

Makes sabbath in the fields, and ever ringeth

A call to prayer.

Hopace Smith. 


\section{VIII}

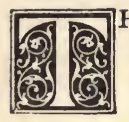

HE whole farm at Overlea might The orchard well be called an orchard, for place.

it abounds in Apple and Pear trees, which are scattered about it, from the point at the north to the foot of the hill on the south.

Tall, fuzzy old settlers they are, with mossy trunks and gaunt branches; but, like the ancient New England human stock, they die game, and are useful to the end. The weather-beaten old Seckels, which look perfectly hopeless, still produce stout, brown, rosy little pears, as sweet as honey, if not much bigger than an overgrown bumble-bee, and the venerable Bartletts, which we threaten every year to cut down, because they look so shabby and disreputable in their torn and mossy old jackets, put off the evil day by mollifying us every September with a crop, 


\section{The Rescue of an Old Place}

which, though not large, still serves to purchase them a reprieve.

Methuselah the Peartree.

One of the conspicuous ornaments of the level space below the northern terrace of the house is an old Pear-tree we call Methuselah, which was transplanted in 1779 , and, in spite of its great age, still bears a profusion of hard, sweet pears, which the housewives consider excellent for coddling, or preserving with barberries. This ancient and honorable old continental, which stands some fifty feet in its stockings, girths ten feet and three inches a foot from the ground, and has a coat so beautifully wrinkled and seamed with age, that our artist friend tells us a Japanese would beg a bit of the bark for a curio, and exhibit it as a precious and artistic possession. In the spring its venerable poll is snowy with blossoms, and though its great trunk is quite hollow within, the six huge branches into which it separates near the base spread wide and strong, and send out from their broken tops vigorous young shoots, on which the fruit grows profusely.

We suppose this to be the original well 88 
known Cushing Pear-tree, as this farm was a part of the colonial grant to Matthew Cushing in 1634 , and was the Stammhaus of that widespread race, which held the property in the Cushing name for two hundred and forty years, the land having descended by will from one to another, so that we hold the first deed, and paid the first money that was ever given for it.

The Apple orchard proper, which is in the shape of a flat-iron, lies in the point The Apple
orchard. of the place, which is quite filled by three or four enormous old trees, which have grown to a great height, and had, when we came, immense branches that arched over and almost swept the ground, their huge mounds of rosy bloom in spring making a wondrous sight.

Since then, with a vague idea of improving them, though some of the wise ones tell us it is a mistake to meddle with such old trees, we have had them pruned, that the sun might shine more directly upon the apples, which failed to color properly in the dense shade. Also, the ground beneath them has been plowed, to the great detriment of their small roots, which, 


\section{The Rescue of an Old Place}

owing to the marshy ground below, lie very near the surface.

Last year was not their bearing year, and not until this autumn could we tell the effect of this surgery, which seems to have had fairly good results, for the yield was satisfactory though not large. The plowing was not done so much for the trees as for the grass, which had been fairly driven out by the encroachments of the Moneywort, which has escaped from the garden and runs riot over the place ; and the pruning was as necessary for the hay-crop as for the fruit, for the great Elm hard by helps to shade all that part of the grounds, and even now the grass, when cut, has to be transported into the open to be cured.

Old Appletrees.

The year we took possession, three trees at this point - a Baldwin, a Rhode Island Greening and a Russet - furnished us with about a dozen barrels of apples. In addition, there are in other parts of the place more old-fashioned trees, like the Seek-no-Further and Early Sweet, that are extremely useful, and fairly productive in spite of their years and infirmities. One of the latter trees is quite a curiosity, for 
half of it is wholly denuded of bark, as if it had been struck by lightning, and the trunk is perfectly hollow, but the grafted stem still sends out very strong and healthy-looking shoots, that yield an abundance of fine rosy-cheeked fruit every other year.

The canker-worm has meddled very little with these trees, but the web-caterpillar has to be waged constant war upon, both in spring and fall, and the last two summers, owing to the preceding mild winter, this pest was particularly active and ubiquitous.

A row of Plum-trees against the east foundation-wall of the old house, which still stands, and makes a good shelter for our Raspberry bushes, seem as if they would do well if we could only cope successfully with the murderous black knot, with which we found them perfectly covered. In 1889 all the diseased portions were cut away, and since then they have sent out a quantity of tall, healthy branches, but no blossoms, from their closely polled stems; we purpose next spring to try the effect of salt bags in the crotches of the 


\section{The Rescue of an Old Place}

limbs, which, we have been told, is a successful way of keeping off the curculio. But from what we read of the necessary efforts to get rid of this pest, we fear that the plums would hardly be worth the trouble, for it seems as if nothing less than a Salvation Army would suffice to combat this persistent beetle sinner.

Iron Pears good for ammunition.

In our orchard are Iron Pears of the good old kind that would serve for ammunition in a field piece in case of war, and some rickety-looking Lawrences, that bear excellent fruit in generous quantities; and there is a picturesque Crab-apple tree which grows quite too near the great Elm to furnish any decent fruit, though it does its best, and strews the ground beneath it with its stony red and yellow apples. The old Cherry-trees were too worthless, so we cut them down. We have but few Peachtrees, though we are told they would thrive against the hill, as they like a northern exposure. We are now preparing to plant a fresh Apple orchard, which ought to be ready to bear by the time the old trees quite give out, and we are grateful for suggestions as to the best kinds for domes- 
tic uses, and eager to know whether the trees will be more likely to thrive in the moist or in the dry part of the grounds.

But there is a charm about this unpro- Charm of ductive old orchard, with its wilderness of the orchard. venerable shrubs along the fence, that no thrifty modern row of fruitful trees will ever possess. As one sits there in the shade on a sunny day, with the white petals drifting down from their lofty boughs, there is a murmur of bees among the foliage, of robins chattering among the twigs, a rustle of leaves and flowers in the gentle breeze, that seems the essence of the many summers gone that have helped to swell their great boles, and to increase their majestic height. From under the arch of branches the green meadow is visible, with wooded hills rising from its margin, among which nestle cottages, white and red, with the faint smoke curling lazily from their chimneys, up to the blue sky flecked with round white clouds. How many years the old trees have looked out upon the quiet meadow, and for how many generations have they dropped their rosy fruit!

In this new country of ours we yearn 


\section{The Rescue of an Old Place}

Old Hing- for stability, for tradition, for something
ham. to link us with that past which goes back so little way behind us here. Perhaps the grafts on these mossy limbs were brought from England by the early settlers who peopled the old colony. Under their shade the sturdy Puritan has leaned upon his spade and remembered the orchards of his native land, which he was never to see again; and now, as the vision grows before our dreaming eyes, we climb the ladder of the past, and are again in Lincolnshire, and the choir-boys are chanting softly in the distance, and the bells are ringing from St. Andrew's Church, of the other Hingham, the gray towers of which we see afar off, instead of the quaint spire of our old meeting-house, whose tenscore years of life seem so little in the older world, where they reckon time by centuries instead of decades.

A Memory of Lincolnshire.

We see the wide green fens, and the fallow fields besprinkled with grazing herds, the rich meadows where the lush grass grows, and where great crops repay the farmer's easy labor; the wolds with their chalk-hills, the thrifty hamlets, the 
sluggish rivers creeping to the sea, the The robin Humber with old Hull at its mouth, the singing in broad bay of the Wash, overlooked by chard.

English Boston, the level pastures by the swift-flowing Lindis, where the great tide came in. The bells from the great towers are ringing, - is that the "Brides of Enderby" we hear? - and so we wander in a dream of the far past, till the boom of the bells resolves itself suddenly into the humming of bees, the venerable towers vanish in the shaggy trunks around us, and we are awake once more, under the bending boughs of the old orchard, with only a robin for a chorister. 

IX

A STRUGGLE WITH THE WEBWORM 
Devoured by worms, like Herod, was the town.

LONGFELLOW.

Nine hundred thousand reptiles blue.

H. BENNETT. 


\section{IX}

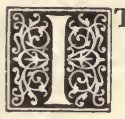

$T$ is a delightful thing to own an orchard, but it is a blessing not The villain. ous webto be enjoyed without fighting for it, since among the difficulties of reclaiming a place, one cannot ignore the necessary hand-to-hand conflict with the various animal and vegetable enemies which lie in wait to destroy plants and trees. Eternal vigilance is the price of vegetation as well as of liberty, and the cultivator who dreams that he can for a moment take his ease in his inn, reckons without his guests of the insect-world, who take short naps, and require as much nourishment as Falstaff. I shall have more to say upon this subject at a later date, but the Apple-trees remind me of conflicts with the web-worm, and I find a treatise upon his manners and customs apropos. As an example of pertinacity, Bruce's spider beside him pales her inef- 


\section{The Rescue of an Old Place}

fectual fires; as an evidence of the apathetic stupidity of man he is unrivaled, and as a menace of future untold horrors he may well be used to point a moral of gruesome interest.

The real end of the world.

Some philosopher has said that "the real end of the world will come when man ceases to be able to cope with the insects." When his time comes the worm is the master of us all, but there is no reason while we are yet stirring about this earthly ball, that we need submit to be devoured by him before our day. And yet, when you come to think of it, that is what the brute is after. Too cowardly to attack man openly, he begins by eating up his provender. Man, being on the whole an easy-going animal, at first pays not much attention; but he only multiplies moderately, and the insect enormously. Where a man will leave a half dozen descendants in a lifetime, a worm will leave one hundred and twenty-five thousand in a season; judge then if this can be allowed to go on indefinitely, and man survive !

Where the inane apathy of the human being comes in, is in not crushing his 


\section{A Struggle with the Web-worm}

enemy while yet insignificant; forever penny wise and pound foolish, man tolerates a moderate evil until it becomes inordinate, and then wastes a fortune which might well have been saved, in doing ineffectual battle with his foe. It is the fable of Epimetheus forever renewed, and the appeal I would now make is to have this Pandora's box closed before the rest of the web-worms escape to plague the world, and help make an end of the race.

It is idle to scoff at this idea as that The webof an alarmist. A few years ago the spring web-worm was an unimportant worm increases in numbers. factor in our orchards. The fall worm gave some trouble, but he was not impossible to cope with. Now, not only do we have to fight for every apple we possess in the autumn, but all through the months of April and May, when work presses, when every moment is precious, it takes not only all the hands on a farm to fight caterpillars, but also all the eyes of the family to detect their lurkingplaces; and this not as one job, but as a perpetually recurring duty for weeks at a time, and all on account of the crying neg- 


\section{The Rescue of an Old Place}

lect by land-owners of their premises, and by town authorities of the webs on their Webs on the own highways, which have been allowed
high-road.

to accumulate, until the country roads have lost their beauty, lined as they are with trees shrouded from root to summit in ghostly webs, under which myriads of loathsome black worms writhe and crawl, and eat their fill, to the shuddering disgust of the wayfarer.

Far and near, not only are the Wild Cherry trees, already infested with the odious black knot, left to spread a second plague among the fruit-trees, but whole orchards are allowed to bear unmolested swarms of caterpillars, their owners preferring to sacrifice their apples rather than take the trouble to clean their trees of the webs.

Communities should take charge of their own worms.

Since the State of Massachusetts has taken the Gypsy Moth in hand, why should not communities take charge of their own worms, and enforce the destruction of the webs by each land-owner, under penalty of a fine, while the street commissioners be made to attend to the trees bordering the highway? 
The farmers who neglect this rapidly Farmers increasing nuisance seem to me like the like the Turk who sits under a crumbling wall, murmuring, "God is great! if it falls it falls!" and takes no pains to get out of the way.

So far as our own little farm is con- How the cerned, some tall Wild Cherry trees that we form is depend on for a screen give us timely notice of the arrival of the pest, and bring us all out promptly to do battle. The worms are fought with fire on the end of a pole, with a tall clipping knife, and with a wire brush attached to the end of a long bamboo rod, which reaches to the very top of the tallest trees, where, being judiciously twisted, it brings down a crop of crawlers for more positive destruction below. The clipping is the most thorough method, for, if done late in the evening, the nest, with all its occupants, can be secured and its contents burned or trampled to death. In this way all the insects can be destroyed, but, of course, it is only possible where the web is on the end of a small branch. Where it lies in the great crotches, the torch or the wire brush must be applied; 
but the former lets some escape, and I am told that when the nests are burned, the fire shrivels the outside of the crawling mass, which falls with the web to the ground, but the caterpillars in the heart of the living ball escape, to crawl up the tree again and start afresh upon their depredations.

The worm has come to stay.

It is of no use to think that you have accomplished your purpose because, after heroic labor, there seems not a vestige of a nest remaining. No sooner do you feel that you have routed the last encampment of the enemy than, presto ! his tents are once more like those of the Assyrian for multitude, and in a day or two you must resume your round to find the enemy bigger and brisker than ever. About three months of the season have to be given up to the two campaigns, spring and fall, till finally a person of imagination begins to feel that the philosopher's prediction is about to be fulfilled, and that the worm has come to stay.

"Of what use are the Cherry-trees?" say the wise; "the worm, after all, is not so bad as the black knot, and compared 
to the canker-worm he is harmless : " but the terror of his multiplication is upon me, and I live in fear of the day when, having ruined all the fruit-trees, and having failed to find the shade-trees to his liking, the worm may take a fancy to investigate within-doors to find a more tempting meal.

A vision of opening the front door in $A \hat{n}$ azuful the morning to find the house encased in future.

an enormous web, under which the worms are feeding on the shingles, and glaring at you from under their silken canopy, besets the imagination. You seize your hat, a brisk young family drops out of it; your coat - there are a score of creeping things inside the sleeves. The breakfasttable is invaded by a squirming throng; others hang from the draperies and wander across the ceilings. Why may not the web-worms become as great a pest to us as the termites prove to the South African, if the apathetic public does not awake in time to the necessity of destroying them while they are yet in the minority?

Here in this town, where the neglect of 


\section{The Rescue of an Old Place}

certain farmers adds so greatly to the labors of their more thrifty neighbors, we have seen these loathsome creatures multiply in a few years to an alarming extent, and it seems as if the time had come to render it a penal offense to neglect to destroy the webs as fast as they appear. Unquestionably, the day is coming when

- some destructive measures will have to be adopted, and the sooner the matter is taken in hand the easier it will be for all concerned to get rid of the evil, and I should be glad if some more powerful pen than mine could be used to hurry this good end.

An evil, trifling in itself, becomes a menace if neglected, and the comparatively inoffensive character of this little brute seems to blind the public to the way in which he is multiplying. A committee to find out how much harm he does might serve as a preliminary to more strenuous measures, but if it were only in the interest of those lovely rustic roads, in which we take so much delight, it would be worth while to clear away so obtrusive an eyesore as these loathsome webs from 106 


\section{A Struggle with the Web-worm}

the waysides, otherwise so beautiful with their wild vines and tangle of bushes.

Moreover, for the pedestrian the multiplication of caterpillars is a distress yearly more and more appalling. After The worm to be met on the sidewalks. the worm has eaten his fill he sets forth upon his peregrinations, to find a sheltered spot where he can become a hermit in a cell, until such time as his resurrection as a moth is in order, and you are obliged to meet him on his winding way at every turn in your path. Country sidewalks swarm with the wretches; verandas are their especial delight; you gather a flower, a caterpillar is crawling up the stem; examine your trees of all sorts, the brutes are making of their trunks a public promenade, up which they hurry at top speed to make a cocoon in the branches; would you rest yourself upon a bench, the caterpillar is there before you ; if you wear a thin gown, you may have the pleasure of viewing through its meshes the wriggling, hairy form of your enemy, just where you cannot get at him. He makes himself at home amid the flowers of your bonnet, he swings down upon a silken 


\section{The Rescue of an Old Place}

He is fatal thread within an inch of your nose. He to Christian character. arouses in the gentlest breast a desire to slay this future parent of thousands; he undermines the character by stirring up sentiments of virulent hostility in otherwise peaceable souls; he becomes a menace not only to existence, but to Christian character, by developing the savage instincts of our nature; and, therefore, on every ground, both physical and moral, he is an enemy of the public peace who should be taken in hand by the authorities and be doomed to extermination.

Should I be requested to provide my enemy with a more precise name than Web-worm, not being learned in entomology, the only term I dare to vouch for is Nasticrechia Krorluppia (to be pronounced English fashion).

To this family I am entirely sure he belongs, but one of the reports of the Department of Agriculture has a good deal to say about a certain Hyphantria cunea, which seems to correspond to him in some particulars, and the same report furnishes for him ten more synonymous names that apparently can be used if necessary. 108 


\section{A Struggle with the Web-worm}

From this abundance I have selected the $A$ descriptive above as the most euphonious and descripname. tive, for nothing could be more appropriate than the term "Shameless Weaver," which, I have been told, is the translation of these polysyllables. Should my particular web-worm require a more formal introduction to the public, it is to be hoped that some entomologist will kindly supply his real designation to those who seek further information concerning this unprincipled reptile. 



\section{$\mathrm{X}$}

PLANTING TREES ONA $L A W N$ 
The gods who mortal beauty chase, Still in a tree did end their race.

ANDREW MARVELL. 


\section{$\mathbf{X}$}

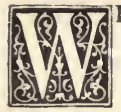

HEN our house was built, and the lawn prepared for their reception, we made our first experiment in moving good-sized trees in the month of January, when we transplanted two large Norway Maples, given to us by a friend on condition that we would take them away at that time, as otherwise they would be destroyed by some grading that was going on where they stood.

Fortunately, it was an open winter, with no frost in the ground, and there was no difficulty about digging. I personally conducted the procession, and insisted upon having the diggers begin at the outside, and work in toward the trunk, so as to save all the little roots. It was slow and careful work, and it took all day to move two trees. They were too heavy to lift with a ball of earth, as we had no special 
Severe topping unnecessary.

appliances for the purpose, for the largest one measured six inches through, two feet from the ground, and had a lofty top.

After the trees were carefully uprooted their tops were cut off, until the main stems were only about eight feet high, and the branches that were left running up from them were also cut back to within a few feet of their union with the trunk. Could we have foreseen the mildness of the two succeeding winters we should have been tempted to prune them less severely. I am almost sure that it was unnecessary, but moving them at such an unusual season seemed to make it wise to give them more root than top. It will take about four years for them to get back their original stature after this severe treatment, but they perhaps have escaped risks of drawbacks by the way. Similar trees in this town, transplanted without topping, though they have lived, have shown signs of feebleness, and I am disposed to think that in the end ours will make the finer specimens.

The holes in which they were set were dug six feet in diameter, and nearly five 


\section{Planting Trees on a Lawn}

feet deep. A gentle rain was falling when the Maples were set; six or seven cartloads of loam were put around them, and when the roots were fairly covered, and the ground trodden closely about them, water was put into the holes before they were finally filled up.

These two trees, planted on the south Great sucside of a gravelly slope, so that the mois- cess zwith ture must run away from their roots more than is desirable, have made so heavy a growth in the last two years, that in the middle of summer we have been compelled to cut out many large branches to admit light, and to improve their shape. In addition to their density of growth, they have shot up fresh stems, between seven and eight feet long, in the two seasons they have been fairly growing, for the first summer they did not accomplish much beyond a good crop of leaves. By the end of July we look to see them grow four or five feet more, as they are fairly set, and in fine healthy condition. The ground about them has been kept open and cultivated, and is heavily enriched several times in the course of the summer. 


\section{The Rescue of an Old Place}

They are so near the house that we use the broad space around them as beds for Geraniums and Heliotropes, which probably detracts a little from the growth of the trees, but at the same time improves their appearance and keeps the earth moist and well stirred up about their roots. When the season is dry they are very thoroughly watered at least twice a week, by leaving the water from the hose running on them from its open mouth for an hour or two at a time.

In April we moved in the same manner courages us to plant others.

Silver Maple, which has grown nine feet and ten inches, and a stocky White Willow, which has been put quite near the house to give us immediate shade, of which we are greatly in need, and which is to be cut down as soon as the Maples are big enough. This last tree, set in a very dry place, has grown a dense head nine feet six inches in height, so that it is now a tree seventeen feet high.

These are the best we have to show, except a Catalpa, which has made a most luxuriant growth, for our Ash-leaved Maple, which was also disposed to make a 


\section{Planting Trees on a Lawn}

record, has been moved twice and so set back. But this growth on a gravel-bank, where no one thought that trees could be made to live at all, is not to be despised. Some of the other trees have grown almost equally well, but were not so large to begin with, so they seem less important.

In that same April the generous friend $A$ generous who furnished us with the large Willow ${ }^{\text {gift. }}$ and the Silver Maple, kindly sent us, in addition, a dozen moderate-sized trees which he was disposed to think would grow faster than the larger ones; and these were placed somewhat at random on the lawn, for they came unexpectedly, and had to be set without much reflection, so that some of them have had to be moved again.

And here we will honestly admit that the landscape-gardener would have been of great use to us, for the lack of experience gives one a feeling of uncertainty about the result of even his best-considered arrangement, which is often disquieting.

We know for one thing that we have closeplanttoo many trees too near together, because $\underset{a b l e}{i n g}$. we never dreamed they would all make up their minds to live, and we discover 
that after taking great pains to make a tree grow, we cannot make up our minds to disturb it for fear it will be in the way in the future, and so we postpone the evil day. Possibly they will do better in their wind-swept situation for not being widely Treesfor separated, and for the next generation,
the next generation. which will be unrestrained by our sentiments, we have provided some small Elms that ought to be good trees by the time the short-lived Maples are beginning to shuffle off their mortal coil. We know that the least enduring of them will outlive us, unless we emulate old Parr, and the famous Countess of Desmond,

Who lived to the age of a hundred and ten, And died by a fall from a Cherry-tree then.

Elmsto be All we ask is that they will hurry to shelour cenotaph. ter us from the burning afternoon sun, to which our front is exposed, and when their task is done, the noble Elms, which are "a hundred years growing, a hundred years standing, a hundred years dying," shall be our monument when this house, like its ancient predecessor, shall have crumbled to ruin. 


\section{Planting Trees on a Lawn}

Impatient as we are to achieve miracles of growth, we might forget how much our little trees are doing were it not for a photograph taken in $\mathrm{r} 888$, which shows them scudding under bare poles, that makes their present height quite imposing by contrast.

In the five years which we claimed of our critics in the beginning, we are now sure that all air of newness will have gone from the knoll, which, even in the second summer, astonished the passers-by, who were most of them unused to the results that can be attained by unremitting exertions.

Against these trees we have no charges Trials with to make of either stubbornness or ingratitude; given the conditions, the results are all, and more than all, we had a right to expect. The only ones that have not been what we could wish are the Hemlocks, which object strenuously to the dry, windy situation, and only live under protest. In vain do we plant nursery trees with good roots ; they dwindle and pine, and refuse to profit by their advantages. Out of over forty trees planted on the lawn and its 


\section{The Rescue of an Old Place}

slopes, they are the only ones that fail to give satisfaction, and we desire to get the better of them if possible.

Tender

No evergreen is so graceful and suggesbeauty of the tive of wild woodland ways as this feathery denizen of the forest, that seems to shrink from the companionship of man. The perfume of its boughs reminds one of camps in the woods, of canoes, of Indian guides, and silent solitudes. For me it has ever a peculiar and elusive charm, and I cannot come in my wanderings upon some majestic old tree beside a granite boulder, as it loves to grow, without a thrill compounded of association and admiration. The Hemlock seems to possess every beauty that a tree can have: its form, whether it be symmetrical with youth, or gnarled and twisted by age, is always impressive and noble; the murmur of its boughs is tenderly musical, its fragrance exquisitely wild and aromatic; its very shyness has a charm that seems to breathe distinction, and, best of all, it is perennially green, so that its blue shadows on the snow give one of the loveliest tones in a winter landscape. 


\section{Planting Trees on a Lawn}

Why, then, since I woo it with such Killed with tender affection, such anxious care, does kindness. it refuse to grow for me? Possibly it is killed with kindness, and some wholesome neglect may be what its shy soul desires, for I notice that the little ones in the swale, half smothered in grass, do not die, though left wholly to their own wayward devices, while the pampered specimens on the lawn lift bare and ragged branches to the sky, from out their luxurious beds of mulching, and are painfully disappointing and uncertain. 

XI

RECLAIMING A SALI

$M E A D O W$ 
Ye marshes, how candid and simple, and nothing withholding and free,

Ye publish yourselves to the sky, and offer yourselves to the sea.

SidNEY LANIER. 


\section{XI}

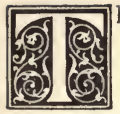

HE ornamental part of the place once under way, we had leisure to give a little attention to the practical, and accordingly we began to wish to utilize some of the waste land lying on the east side of the farm, where the salt water made free inroads during high tides into a half acre of otherwise good mowing, and here we learned the meaning of an interesting parable in Roman history.

The fable of Metius Curtius plunging Metius on horseback into the morass which had Curtius avarning. opened in the Roman Forum, because the oracle had declared that only the best thing in Rome would be of avail to close it up, must have been invented simply to show that the Romans, great engineers as they were, fully recognized that filling up a marsh was a well-nigh endless job, which would require the sacrifice of 


\section{The Rescue of an Old Place}

the best blood and treasure of the state before it was accomplished.

No man can resist draining a meadow.

In spite of the illustrious warning given by $\mathrm{M}$. Curtius, there lives not a man with soul so dead as not to be fired with ambition to make dry ground out of his meadow, if he is so unlucky as to own one; and he always starts in with figures on paper to show what a fine income of hay is to result from a comparatively small investment of labor and gravel. But the work goes on, then more work and more gravel, till finally the account of this part of the business gets mislaid, so that by the time the far distant hay crop begins to materialize, a haze has settled over the amount of capital (literally) sunk, and only the hay returns are brought prominently to the front.

When we first surveyed the half acre or so of salt-grass which had been left over on our side of the fence when the road was built across the meadow, it did not seem of much importance, one way or the other. The English grass grew luxuriantly down to the edge of it, and the soft, fine salt-hay was excellent for bedding, the I26 


\section{Reclaiming a Salt Meadow}

only objection being that it was so palatable that the horses ate up their mattress before breakfast every morning.

After the causeway was constructed across the wet ground behind the stable to Winter Street, there did not seem very much reason for meddling further with the marsh, but given a gravel-bank at one end of a farm, and a swamp at the other, and you may depend upon it there will be a marriage between them at no very distant date.

The intercourse between the two of our The hill acquaintance, once begun, was seldom interrupted; the more the meadow saw of marsh intermarry. the hill the more it wanted to see, and, with a perversity only to be found in meadows, the more it was given the more it wanted of the same kind.

At first it seemed as if a few cartloads of stones dumped in the lowest parts, where the water stood longest, would be all-sufficient, but the amount of material that this anaconda of a marsh can stow away is, to use the slang of the day, phenomenal.

Piles of stones, rubbish, sand, boughs, 


\section{The Rescue of an Old Place}

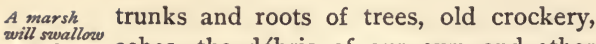
everything. ashes, the débris of our own and other people's places, it "swallows them all without any remorse," till the top of the fence along the road has nearly disappeared from view, and still it calls for more, and continues to subside.

Across the street our neighbors have tried the experiment before us, so that we are aware that it is unsafe to put soil on this gravel until after it has had a chance to settle for a year or two, otherwise a high tide is liable to come and wash away all the loam out to sea.

As the surface rises the fresh water runs off less easily, so that the enterprise gains in magnitude as it goes along, and the space covered promises to turn out a whole acre instead of half a one, before the job is fairly completed.

A capacious Still, time and the hill will fill even this mav. capacious maw, and, though at present in a transition state, the meadow gives promise of a beautiful grass field, which, it is to be hoped, will repay all the labor of its construction.

The tradition goes that the building of I 28 


\section{Reclaiming a Salt Meadow}

the street behind us across his meadow-lot Building a was too much for the gentleman who zuall. owned the place at the time it was made, and that he never recovered from the shock of having his estate thus divided and his house-lot spoiled. The enterprise was a formidable one, for it involved the construction of a great stone arch across the stream that drains the meadow, and the laying down of heavy plank rafts for the piers of the stone bridge to stand upon. For years the road would be built up to a good height every summer, and then would subside under the influence of the high tides in the autumn and spring, till it seemed as if it would never hold its own, and keep its head above water all the year round.

But constant renewals of the layers of $A$ good gravel have at length made of it so subcausezvay.

stantial a causeway, that nothing but the very highest of spring-tides prevails against it, and such water as finds itself on our side forces itself rather under than over it.

Those of our neighbors who have reclaimed land from the main meadow on 
Land reclaimed from the marsh.
Patience necessary to change the face of nature. the other side of the road, have done so by first building a kind of rough dam of stones and clay, and then gradually filling in behind this dam with rubbish and stones and sand until they reach the level of the street. When properly covered with loam, after having had plenty of time to settle, this well-watered foundation affords excellent soil for grass, which grows upon it with great luxuriance.

As the road acts still further for a dam between us and the meadow, our task becomes simpler, and we can reclaim our piece of land with far less trouble than our neighbors have had with theirs, and we are encouraged to look for equally good results.

But it is distressing to see the surface of the hill, which we would fain see rolling in graceful slopes to the swale, waving with the forest of our imagination, still vexed by the presence of carts and horses, and torn by the torturing spade.

He who undertakes to change the face of nature must needs have patience. Monarchs like Nebuchadnezzar may hang gardens in the air in a few months, or a 


\section{Reclaiming a Salt Meadow}

Louis Fourteenth may construct a plea- Freakish sure-ground like Versailles, by the aid of Nature reforty millions and the genius of Lenotre, sents interin a few years; but one who has not the resources of an empire at command must imitate more closely Nature's own deliberate and tortuous methods, often seeing the labor of years destroyed in a moment by an unforeseen freak of the old dame, who resents being interfered with, or finding to his dismay that his own scheme has been a mistaken one, and must be revised.

An illustrious townsman of ours started like ourselves with a bit of salt meadow, in which he laboriously constructed a pond, spending his hours of ease from the cares of state in building a wall about it, to make a neat and appropriate curb. But after this was accomplished, with much trouble, it proved not to be at all what he wanted, so that there was nothing for it but to fill the hole, and with months of labor bring the meadow into a smoothly turfed field.

Our day of repentance has not yet The marsh's dawned, but we have a fear that it lurks yazwning 
Her malice. somewhere behind the horizon. Some modern Metius Curtius may yet have to be found to help fill up the marsh with a horse and wagon, for that Charybdis has already taken toll more than once from a dump-cart, though she has not yet succeeded in swallowing it up in spite of various malicious efforts. She has designs upon the cow, only frustrated by careful watchfulness, and to her deep treachery there is no end. The family purse she long ago put in her pocket, and her mouth yawns for all the future revenues that may accrue for her benefit. She has eaten up a large part of a neighbor's hill, besides taking most unbecoming bites out of our own, and if ever future generations weave a legend about the ancient dragon of Overlea, which demanded a victim every summer, it will be traced by the unraveler of myths of the period, to the unremitting appetite of this hungry meadow.

Loveliness of the viezw in spring.

But who, looking out on some sweet spring day upon that beguiling distance, could believe ill of anything so softly lovely as the picturesque marsh of which our field is the fag-end. In the foreground, 


\section{Reclaiming a Salt Meadow}

the richest tones of green are gently blending in the grass ; in the middle distance a point runs out towards the stream, laden with fruit-trees in snowy bloom; the Willows near and far are putting on their gray-green coats, making a tender shimmer around their swaying branches and graceful twigs. The little river winds, blue and full, here and there amid the grassy The winding river. stretches, and the distant hills are full of opalescent hues of emerald and pearl, with red of tree-stems, and faintest green hints of foliage, such as Monet would love to paint. The houses of the port, not yet quite veiled by leaves, make spots of white and yellow and red against the deepening background of Elms and Maples. A streak of blue still indicates the harbor; by to-morrow it will have disappeared, for the vision changes like a kaleidoscope, - the white of Pear blossoms passing like a cloud, to be succeeded by the rosy blush of Apple buds. Each day some well-known feature of the winter landscape grows fainter as the leaves expand, till of a sudden you look for it and it has gone, and in its stead are the full- 
robed trees. Over all domes a blue sky streaked with faint white cirrus clouds, only the azure reflected in the placid stream below.

- A picture exquisite, but evanescent.

An impressionist alone could catch this fleeting beauty of early May - to-day one thing, to-morrow another - and fix it eternally upon his canvas. The tender grace of early spring, and the glowing glory of autumn are alike evanescent and wonderful expressions on this smiling meadow face. Like a dream, this hint of ineffable beauty melts away, and the impression gives place to a reality of vivid green field and dark blue water, which will make but a pleasant inland landscape until the August sun burnishes it into ruby and gold, and makes it once more a vision for a painter.

The exquisite must perforce be evanescent, that no touch of commonness may mar its distinction. "The tender grace of a day that is dead" haunts many a spot, otherwise tame enough, with a memory and a knowledge of its capabilities, that make it forever dear and beautiful to him who has seen it under that enchant- 


\section{Reclaiming a Salt Meadow}

ing glamour lent by a season, or an hour, Memory of which imprints upon the brain a picture spring.

that can never be forgotten. And when at other times of year I look upon this far reach of often-changing meadow, there abides with it always a memory of the soft and tender charm of early spring, that no reality of November-brown or winter-snow can wholly drive away. 



\section{XII}

TERRACES AND SHRUBS 
How could such sweet and wholesome hours Be reckoned, but with shrubs and flowers?

MARVELl. 


\section{XII}

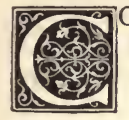

ONTINUING our practical efforts, we were moved to enlarge house. around our dwelling the space which, after a year's occupation, we found rather too contracted to be entirely satisfactory; for, though we have no especial preference for terraces, which used to form a feature of many old-fashioned homes, the conditions of our houselot have forced them upon us on three sides. As I have before stated, the flat top of the knoll is very limited in extent, so that, even in building, we were forced to cut our coat according to our cloth, and support the rear of the house with a high basement, to serve for laundry, dairy, and other offices, instead of adding the more usual $\mathrm{L}$, or wing.

The width of the lot at this point would not allow of more than ninety feet between us and the highway, even by set- 


\section{The Rescue of an Old Place}

ting the building as far back as possible; and when this was done, leaving a gentle slope from the front door to the road, the ground on the north and south sides of house fell with such abruptness from the foundations that no room was left even for a passage-way.

How it was remedied.

This lack was remedied on the north of the house by constructing a terrace sufficiently wide on top for a tree or two, and some shrubbery to mask the foundations, with plenty of space for climbing things to grow over the veranda. This bank, supported on the east by the heavy wingwall of the house, slopes to a driveway below, which leads to the stable behind. It is high and steep, but well sodded, and rather adds to the commanding effect of the house, beside serving to break the height of the building at the back. A flight of steps at the rear of the veranda leads to the drive below, and some goodsized Pines have been planted there to - still further hide the basement.

Fault in the main approach.
The main approach was not planned with sufficient consideration for anything but convenience, and consists of a semi- 


\section{Terraces and Sbrubs}

circular driveway to allow the house to be easily reached from both ends of the town, but it would be better if the front door were only accessible from the north to carriages, which would give us an unbroken stretch of grass on the east and south, whereas now there is a half-moon of greensward in front, inclosed between the driveway and the street, thickly planted with trees, destined soon to form an effectual screen betwen us and the dusty road.

South of the house, near the highway, the ground slopes gently into the swale, struct a which, with its groups of trees, forms a side lawn of uneven surface, bounded at the rear by the hill, with its rising tiers of little Pines. Near the dwelling, however, in order to get any greensward or shade at all, we were forced to build, of stones and gravel, a terrace some twenty-five feet in width at its narrowest part, to support which about two hundred feet or more of massive wall were constructed. This wall is low in front, and buries itself in the grassy slope, but where it curves around the knoll at the rear, it 


\section{The Rescue of an Old Place}

is six feet high, and makes a warm background for Grapevines, and the hot-beds, which are placed below the vines, fronting the south. A steep bank, thickly sodded, descends from the level of the lawn to the top of the wall, which is also covered with turf. This sunny south terrace is the very spot for the old-fashioned Rose bushes which we have transplanted hither from the other parts of the place, and here, too, is a bed for more delicate specimens, which can be protected by a glass frame in the winter-time, as well as a tree to shade the south windows from the heat.

The wall was quite an important construction, and I am afraid to say how many tons of stone went into it, for the largest portion of it is underground, the results being very solid and substantial.

Other ter. races.
Behind the house, on the basementlevel, is still another curved terrace, from which a grassy cart-path leads down to the swale and the hot-beds, and here the various walls are utilized to protect rows of Currant bushes above, and Raspberry bushes below, which are easy of access from the kitchen-door. 


\section{Terraces and Sbrubs}

To cover all this expanse of gravel Muchloam foundation required untold quantities of required.

loam, so much, indeed, that we thought ourselves fortunate if we could allow an average of four inches over the whole surface of the lawn, but this meagre allowance seems to afford sufficient hold for the grass-roots, and heavy annual dressings of compost add continually to its depth. It is rather a curious study to watch the formation of soil, and the gradual way in which the sand below is transformed by the roots - first into yellow, and then into black loam. How long, we wonder, will it take before a foot of soil is obtained over a surface treated as this lawn is treated, the fine grass dropped from the lawn-mower being left upon it without raking, and the drainage from the heavily enriched trees always helping it along, in addition to its own annual dressings?

The shrubs on the knoll, at first scat- Impossible to tered about rather promiscuously, as they shrubs. increase in size we are struggling to group properly, according to the lights thrown upon this subject by our reading, but the 


\section{The Rescue of an Old Place}

Lack of articles we have carefully studied on this material. topic presuppose a great number of bushes of one kind to begin with, and where you have perhaps three Golden Spiræas, and a half dozen Lilac bushes, and a hardy Hydrangea or two, and a few Deutzias, and Weigelias, and other heterogeneous things in variety, the question is to set them so that they will produce the effect of twenty-five of each. We have managed it so that really the shrubbery appears rather crowded, but it has been done in a manner to horrify the authorities.

A sketch in shrubs.

We have treated our landscape very much as a painter would his canvas. We dab in a shrub where we think it will produce the effect of half a dozen, and if, after a few months, the picture seems to require its removal, out it is scratched, and set in another spot, and thus, in true amateur fashion, we feel our way toward a final result, for we find things never look when they are little as they do when they are fairly grown, - the usual experience of amateur gardeners.

The best that can be said for this method is, that the results are unconven- 
tional. I have discovered that a land-Mannerism scape-gardener gets a style, a mannerism, fessional like a poet or a draughtsman, and that, gardener. after some experience, you can detect the professional manufacturer of a garden by the receipts on which he works. Twentyfive Spiræas here, twenty Deutzias there, Viburnums one dozen, Lilacs in variety, Forsythias eight; a bushel or two of golden Evergreens mixed with Juniper and Arbor Vitæ, at such a point; a hedge here, curves on this side, straight lines on that, etc., etc., - it is all reduced to a system, and the results, if repeated in the same town, are monotonous.

We are bound, having gone in for it, to defend the natural method. If the results of the artificial are more satisfactory, the execution is not half the fun.

Can there be, I ask you, the same enjoyment in sitting down to watch the growth of a border of shrubs that somebody has set out for you, that there is in dragging the few you have planted yourself out of their holes and transporting them to a more becoming place, as you would a flower on a bonnet ? 


\section{The Rescue of an Old Place}

We give our shrubs an airing.
Parable of the Owl and the Fox.

- Anybody can put in a tree or a shrub and let it alone, but it takes nerve to wheel it about like a baby in a go-cart.

We have neighbors who employ the conventional methods with dazzling results, but, on the whole, we doubt if their vast and imposing plantations give them as much enjoyment as our more personal intercourse with our little family of growing things. We are quite sure that each scrubby little Pine on the hill is dearer to us than a thicket of well-fed trees planted by a nurseryman.

"You will know my children," said the Owl to the Fox, with whom she had made a compact to spare them, "by their being the most beautiful little darlings in the whole world." But when the Fox came to the nest full of big-eyed, long-billed, unfledged frights, he failed to recognize the description, and ate them all up under a misapprehension. De nobis fabula.

We are afraid that most people would pronounce in favor of the upholstering of the professional, rather than of our private efforts at lawn-furnishing, but we can recommend our method on the ground of 


\section{Terraces and Shrubs}

economy, both of material and of amuse- our shrubs ment, for there is no reason why this play move as a should not go on forever, like a Wagner $\begin{aligned} & \text { Nezw I } \\ & \text { citizen. }\end{aligned}$

opera. It has its surprises too, in the way of some happy effect that you had not imagined, and again, you are horrified at the outcome of some arrangement that seemed felicitous. We have got our own shrubs so beautifully trained now, that they do not mind moving on the first of May, any more than an old New York citizen. Up they come, blossoms and all, and never drop a petal, but go on blooming serenely in their new home as if they had always been there. One spring we had from a kind friend a present of a box of rare and beautiful little shrubs, the very names of which it took a day to look up. We knew they were coming, but not what they were to be, so a bed was prepared for them within easy reach of the hose, and, when they came, they were set out carefully, in the midst of an April snowstorm, and a cold wind, which nipped their poor little half-opened leaves most cruelly.

After they were all arranged, and the 


\section{The Rescue of an Old Place}

A muddle of weather had moderated sufficiently for shrubs. one to study the labels, we found that the arrangement would have driven a gardener wild ; future trees, a hundred feet high, having been set side by side with burly little shrubs, which at present look much more important than their (to be) stately neighbors. What with snow one day, and burning heat the next, combined with steady dry weather, those shrubs have had a strug. gle for existence, in which they have been sturdily abetted by their natural protectors. The hose one minute, and newspapers and branches of trees the next, were called upon to supply the deficiencies of Nature, who was more than ever capricious during that extraordinary season, and since at the end of the summer they were all well and firmly established, it shows what care will do to defy the inclemencies of the weather. After a year or two they will have acquired the customs of the place sufficiently to be moved where they will make the best show, but before they reach their final resting-place it is possible that they may have several halts by the way. With a ball of earth attached to the 


\section{Terraces and Shrubs}

roots, traveling does not seem to hurt them much, though no doubt it retards their growth somewhat, which is all the better if they are to be kept in proper proportion to the place, which is not adapted to anything very gigantic.

Of one thing I have become certain in Looking, this limited experience of landscape-garforward. dening, and that is, that the pleasure is in the doing, in the vision of the mind, in the ever-expanding hope for the future. When the trees have grown too large to move, and the shrubs are irrevocably rooted, we shall surely be no happier than now, when they are viewed in a halo of imagination. 



\section{XIII}

EVERGREENS IN SPRING 
"Come to me,"

Quoth the Pine-tree,

"I am the giver of honor.

My garden is the cloven rock

And my manure the snow ;

And drifting sand-heaps feed my stock,

In summer's scorching glow."

EMERSON.

O Hemlock Tree! O Hemlock Tree !

How faithful are thy branches !

Green not alone in summer time,

But in the winter's frost and rime.

LONGFELLOW. 


\section{XIII}

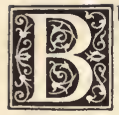

UT the question arises, will those Depressing little little trees on the hill ever at-ifers in tain a satisfactory growth? We Spring.

have various opinions on this matter, our answer being more or less affected by the season at which it is put, we have a few ups, and a good many more downs about it. For instance, I know few things more depressing than the sight of conifers in May, when every deciduous tree is putting its best foot foremost, and giving promise of a fine crop of leaves. The Pines and Spruces and Firs which have gladdened our eyes all winter, with their fine green masses relieved against the snow, or standing up bravely from the brown grass in rich contrast to the barrenness around, now begin to show the sere and yellow leaf. The March sun and winds have burned and browned their tips, the winter storms have buffeted their 


\section{The Rescue of an Old Place}

branches, and torn great gaps in their outline. Their new shoots are all hidden under a little tight white, or yellow, or brown nightcap that looks dried and wizened, as if no promise of life lurked underneath.

When the snow melts sufficiently for one to walk abroad among his plantations, he views them with a feeling akin to despair, so unlikely do they seem to recover themselves. Some branches are entirely dead, the tops of others are winter-killed, a few have turned copper-color from root to crown, and, beside the bright green of bursting buds and springing grass, the best of them look worn and dingy by contrast.

They pluck up their spirits.
Not until the middle of May do they pluck up their spirits, pull off their bonnets, and show that their apparent deadness resulted from the fact that they take their season differently from their gayer neighbors, and wear their winter furs, however rusty and inappropriate, far into spring, while all the others have come out in their new clothes of brightest hue. Some years June will be here before they condescend to put out the green tassels I54 


\section{Evergreens in Spring}

which are their first adornment, but through the month of roses they do their prettiest, and hang out their banners with the best.

Some of the authorities recommend the planting in month of June as the most desirable for Fune. transplanting evergreens, but my experience would lead me to the conclusion that with them, as well as with hard-wood trees, the period before the bursting of the buds is more satisfactory than the time when they have already begun to swell. Seasons vary so decidedly that a few warm days may hasten the new shoots, and they may be three inches long before you think of going for trees, so that they droop discouragingly after transplanting, and sometimes never brace up again. This is particularly the case with Pines, which have a way of drooping their little brown heads despairingly, and refusing to stiffen, in which case, if they cannot be freely watered, they are sure to die.

This year the warm days in April so quickened all vegetable life, that, when Pines need water. we set forth in the middle of May in search of new trees for the hill, we found 
to our surprise that the green tassels on some of the trees were as long as one's finger, which gave us a pang lest we were already too late for the best satisfaction. Wego in However, as there had been already
search of fresh Pines. some six weeks of unprecedentedly dry weather, and signs of rain were in the atmosphere, it seemed that if there was any chance at all, now was our time. We accordingly arranged for a morning among the Pines, and, accompanied by a big farm-wagon to bring them home in, we wended our way along the winding country roads, until we came to where the young trees abounded, and we could select our specimens.

There is little doubt that the stocky, bushy trees of close, heavy foliage, not more than two or three feet high, are the most likely to live and do well, but there are days when one's ambition outruns one's discretion, and, revolting at the slowness of the growth of the little ones, he desires to realize his forest immediately, if only for one summer, and so, like a child who plants his sand-garden with blooming flowers, ventures on a load of I 56 


\section{Evergreens in Spring}

trees five or six feet high, in hopes that, after making a brave show for a few months, they will be aided by some happy freak of nature to take root in earnest.

But planting Pines on a dry hillside is A lottery in like investing in a lottery - the success trees. of the enterprise depends wholly on the sort of weather that immediately follows, and who can reckon with that? Talk of the vicissitudes in the life of a broker what are his uncertain and incalculable quantities compared to those with which the farmer and gardener have to deal ? A broker can abstain from buying bonds and stocks if he will, but the farmer has to plant when the time comes, and take his chances, and for surprises the weather can give points to Wall Street any day. With the largest experience and judgment you can no more reckon securely on the coming down of rain, than of Bell Telephone, or Calumet and Hecla.

No sooner are one's trees planted than he becomes a bear upon the weather market, but this summer, Old Probabilities has made a corner with the bulls, and kept rain up persistently, so that the wisest 


\section{The Rescue of an Old Place}

calculations have gone agley; and if Paul plants, and Apollos declines to water, what then?

To return to our expedition. There was an easterly tang in the air, a smell of rain that promised well for the morrow, though in the shelter of the trees all was warmth and sunshine, and bursting buds. Upon the rocks the Lady's-slipper was waving its rosy blossoms, tempting us to add a few roots of it to our shady garden, where it has thriven well. The Beeches and Birches were full of crumpled leaflets, Anemones were blooming by the wayside, the oak-tops were reddened with the flush of early leaf-buds, the forest was astir. Along the fences ran the busy chipmunks, saucily chattering, with their bushy tails trailing behind them. The wood robins were singing in the thickets, and the thrushes challenging us from wayside bushes. In northern Maine one hears always in summer the tender song of the Peabody bird in such places, but here it occurs but seldom, and I missed it from the woodland sounds, of which the air was full. The Witch-hazel stared at us with 


\section{Evergreens in Spring}

its wicked-looking eyes, and the Hemlocks hid themselves behind the Alders.

When at last we came to the clearing, we found Pines in plenty, but, unfortunately, the soil was rocky, and the trees load of little were hard to dislodge, and did not come up with as good a ball of earth as in the sandy hill where we had found them before; but we packed them well away in the cart, with moss about their roots, and a rubber blanket to keep off the sun, and pretty soon the wagon was nodding with trees four or five feet high, closely jammed together, and Birnam Wood was on the march for Dunsinane.

The hill had been dug the day before, and some twoscore holes prepared for the new-comers, so that by noon-time those of the first load were all firmly wedged into their beds, to be staked and tied later, to prevent their rocking with the wind, which gives them at present quite the air of a paddock of frisky young colts, carefully hitched to prevent their getting away.

That night there was a brisk and most encouraging shower, and the next day, after the rest of the holes had been filled 


\section{The Rescue of an Old Place}

with a second load of Pines, there came down quite a respectable rain, so that we greatly plumed ourselves upon our foresight in having got our trees in the nick of time, just as the drought "broke."

Disap. But, alas, for the prescience of man, and pointment. for our corner in Pines! We mulched them all well with sea-weed, to keep in what moisture we might, and waited confidently for more rain; but no rain came! Two weeks more of dry weather ensued; many of the green tassels hung sadly down, a cold, dry wind blew, twisting and turning them in every direction, and mercilessly whipped the branches about, giving the poor things a cruel foretaste of what they are likely to encounter as time goes on. If the new trees look about upon their well-rooted neighbors, they must be struck with the havoc made upon them by the northwest wind. It is always the northwest side of a tree that is brownest and thinnest, and which shows the most broken branches, and the greatest number of withered, copper-colored spines.

Not until the last of May did the rain come down in earnest, too late for any I 60 


\section{Evergreens in Spring}

but the most healthy of the Pines to reap the benefit of its invigorating freshness, and they still had the hot summer before them.

To show the importance of moisture to A tree a Pine, I will add that among the trees hospital. brought, there were about a dozen that had no ball of earth attached to them, and reached here with perfectly bare roots. Knowing it was useless to set them on the hill in this condition, they were all planted in a very wet place at the foot of it, which is kept as a nursery for decrepit and rootless trees. If from anywhere we receive a tree poorly provided with roots, or of drooping and unhappy aspect, or if we bring one home that looks unpromising, into that moist spot it goes, and never a tree has perished there yet, no matter how forlorn a specimen it was when it went into the ground. This nursery is called the Tree Hospital, and we find a year in it is a cure for most of the ailments that roots are heir to.

In this last experiment, the ten trees planted there, though quite the worst of the lot, never showed a sign of wilting 
through all the dry weather. Their tassels stood up straight and stiff, of a clean bright green, and, though so unpromising to start with, they will probably in the end leave the others far behind. Even the Hemlocks, so troublesome on the lawn, thrive in this low and sheltered spot, where we have finally sent the worst of them for repairs. I have been told, by one who knows, that what the Hemlock cannot abide is the March sun, which does mischief, while the blaze of summer is harmless to it.

Hemlocks at the Arnold Arboretum.

I was shown one day at the Arnold Arboretum, near Boston, the north side of a hill, steep and rocky, but clothed with giant Hemlocks from its lofty summit to the burbling beck at its base. No nobler sight can be imagined. I entered this forest at twilight, and I found it a temple, solemn and silent. The majestic trunks rose from their rocky base at wide intervals, climbing one above the other to the crest of the lofty eminence they crowned. Their close-knit branches far overhead formed a dense canopy through which the failing light came dimly, as befits a temI62 


\section{Evergreens in Spring}

ple. So wild, so sylvan a spot, within the $N 8$ foreign limits of a great city, can be found in no park shows $\begin{gathered}\text { psight. } \\ \text { such }\end{gathered}$

European park, however magnificent. It is unique and singularly imposing. On the southern slope of that hill no Hemlock grows, showing that what this noble tree demands for full development is shade and coolness, and shelter from summer winds, which burn and blight. That glimpse of ancient woodland, ages old, will always linger in my memory as a link between the bustling present and the silent past. The busy city presses around it, the hum of traffic is near. You step aside from the highway, pass a gate, cross a tiny brook that tumbles as carelessly at the foot of the hill as if it were racing through the wilds of Colorado, and you enter a domain apparently as remote, venerable, and silent as when the Indian was the sole occupant of Shawmut and found his way through the trackless forest to his hunting-grounds. A little path worn by the foot strays along beside the laughing stream; other paths may lead over the hill, but in the dimness I failed to see them, and the solitude seemed unbroken. 


\section{The Rescue of an Old Place}

The forest Night was falling, the air was chill, the at dusk. murmur of the leaves far above was barely audible ; the impression was indescribably solemn and church-like, as if the aisles of some great cathedral were there stretching away into the shadowy distance, full of mystery.

Stately and strong the old trees stood, as if they might be as eternal as the rocks and hill, and beautiful they were in their silent majesty, uplifting their venerable heads to the gray evening sky which had domed over them for centuries.

On an opposite hill a grove of young evergreens was springing up.

The Director looks "That, too, will be fine in a hundred forward. years," said the Director, as we passed out of the great gate; and, with a thought of my baby forest at home which, perhaps, in a century or two, may be worth while, I went away grave but rejoicing, for I had seen a noble sight. 
XIV

THE LOVE OF FLOWERS IN

AMERICA 
Fables were not more

Bright, nor loved of yore;

Yet they grew not, like the flowers, by every old pathway.

LEIGH HuNT. 


\section{XIV}

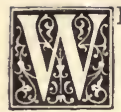

HILE we and our neighbors are doing our best to stock our grounds with ornamental shrubs and blossoms, it is discouraging to be told by some of our periodicals, which are probably edited by gentlemen who live chiefly in towns, that Americans do not love flowers, because they are used among the rich and fashionable in reckless profusion, for display rather than enjoyment. It is also claimed that we are not a flower-loving people, because we accept botanical appellations for our indigenous plants, instead of giving them simple, homely names like the charming ones with which familiar flowers have been christened in older countries.

To this may be answered, that what ostentatious dwellers in towns are guilty of is by no means to be accepted as a national trait. The place to study the characterisI67 


\section{The Rescue of an Old Place}

An old New tics of a people is not among the very England town. rich, but among those in moderate circumstances, who make up the bulk of the inhabitants; those who occupy its longer settled regions, and best represent its individual and continuous modes of thought. And when I see how little these idle talkers know about what country people feel and think, I wish that our urban critics could walk though this ancient town, and be introduced to its flower lovers, and get a glimpse of its interesting gardens, before they make up their minds so positively about the tendencies of our A test of people. Here can be found the American American character. race at its best, unadulterated by foreign admixture, or perverted from its instincts by the pressure of conventions; a people that has lived on the soil for two hundred and fifty years, and has had time to develop its characteristics, - a much better test to judge by than the floating population of newer towns farther west.

Whoever has driven through New England or the older middle States, cannot doubt that there, at least, the people truly love their gardens, and the house plants 


\section{The Love of Flowers in America}

with which their windows, in winter, are Widespread stocked. Even the humblest dwelling has fove of

its row of flower pots, or tin cans, well filled with slips of Geranium, or other bright flowers; and the hours spent over their gardens by gentlewomen who cannot afford a gardener, are the best proof that the affection they have for them is a real and ardent one. I have known many a house mother, burdened with domestic cares, to rise before day to snatch an hour for weeding or watering her little border, that its fragrant contents might be of avail for a friendly gift, or an adornment for her own table. It is the rarest thing, in a New England village, to enter a room in summer and find no flowers disposed about it; and in the winter the eager question, "How are your plants prospering?" often comes before the conventional inquiries after the health of the members of the household. New varieties are discussed and exchanged; there are rare Chrysanthemums to talk about in autumn, and choice Tulips and Hyacinths to be complimented in the spring, and each one knows what her neighbor's garden is most I69 


\section{The Rescue of an Old Place}

.famous for, and who is the most successful in her general management of her pets.

Many women experienced bota. nists.

Many women are experienced botanists in their own locality, and can tell where every wild flower of the region is to be found. They rejoice, too, in the discovery of a new weed with as much enthusiasm as an astronomer shows over a fresh comet. Most of the men who live in the country are too busy to give much time to flower-gardens, but they show great interest and pride in those so carefully tended by their wives and daughters, and are ready enough to lend a helping hand, even though they may pretend to begrudge the space taken from grass or vegetables, for what they think it their duty to call an idle diversion. But given a retired merchant with not much to occupy his mind, and the chances are that he will soon be wearing himself out in loving labor among his Rhododendrons and Roses, taking pride in having the earliest and largest blossoms in his parterre, and conferring in a friendly way over the fence with his neighbors, who stop to consult with him on the best way of dealing with insect pests. Of course, 


\section{The Love of Flowers in America}

in the remoter West, life is too strenuous to leave much space for flower-gardening. Flowers are often seen growing in a little inclosure on a frontier sheep-ranch, which cost not only labor but self-denial, and yet they are hardly seen once a year by any save their owner. The care which it cost the mothers and daughters among the early emigrants to transport seeds, and slips, and roots of the old home flowers from New England, to brighten new homes in the West, has often been described, and the love with which these flowers are cherished by their descendants is well known.

It is to these people we must look to discover whether the love of flowers and gardening is implanted in a people, not to the wasteful and luxurious dweller in the town, who only uses flowers as a pretext for wanton expense. It should not be forgotten that aside from this extravagance, which may show itself in the purchase of flowers, as in the purchase of other luxuries, simply because they may be rare and costly, great numbers of people in the city buy flowers habitually 


\section{The Rescue of an Old Place}

because they love their beauty and fragrance.

The common names of flowers.

As to the nomenclature there is this to be said : In older countries the people and the flowers lived together long before the botanist appeared, while here the botanists came with the early settlers to an unexplored field, found the new flowers, and named them before the people had become familiarly acquainted with them. The State flower of California was introduced to the children of that commonwealth as the Eschscholtzia before they could spell it, but this does not prove any lack of love or admiration for it on their part. They have a pet name for the flower, too; and in all the older settled parts of the country, wherever a plant or flower is so abundant, or useful, or obtrusive that there is need to speak of it, a name is found at once. The children of New England call the wild Columbine Meeting-houses, from their shape, no doubt, and with them Viola pedata is the Horse Violet, perhaps from its long face. The Houstonia, which is Bluets in some places, is Innocence in others. In north. 


\section{The Love of Flowers in America}

ern New Jersey, the Marsh Marigold of other regions (Caltha palustris) is invariably a Cowslip. Some children, gathering Pet names Dogtooth Violets by the handful within givento sight of Trinity Church spire, when asked children. the name of the flowers, expressed much surprise that the inquirer had never heard of Yellow-bells. Even Shortia, which hid away from botanists for a hundred years, had a name which was common enough to answer every purpose, and the man who first discovered it in any quantity was told by the dwellers in the mountain hamlet, where it was spreading over acres, that it was nothing but Little Coltsfoot. Even where botanical names have not been adopted outright as common ones, they have often been changed, just as Pyxidanthera has become Pyxie to all the dwellers among the New Jersey Pines. There are plenty of common names in every locality which have never found their way into the botanies.

American women wear flowers for adornment more generally than the women of any other country. This of itself is proof of the genuineness of their love for flow- 


\section{The Rescue of an Old Place}

ers. It is absurd to imagine that a custom so universal is based on any sham or passing fashion. The desire for display is prevalent enough, beyond question, but if any one doubts whether the admiration for flowers is an acquired taste - because

Wearing of it is fashionable to wear them - let him flowers not a mere faskion. carry a handful of them through a city street among groups of children, where unsophisticated nature will find expression. The keen delight of these little ones, who will always accept such a gift, shows that the affection for flowers is an original instinct, which is as strong in this country as it is anywhere. Fashionable freaks and follies pass away, and flowers would have their brief day like any other craze, if the regard for them was artificial or fictitious. The flower-dealers of the country need have no apprehension as to the future of their industry. It is based on one of the elementary wants of our nature. Flowers will be loved until the constitution of the human mind is radically changed.

To those writers who maintain, quoting Miss Wilkins's stories to prove it, that 


\section{The Love of Flowers in America}

"flowers are an accident, not a daily in- The sentiterest, in villowe life" in New Fngland ments of terest, in village life" in New England, New EngI would say that he who takes this ground land people can scarcely be familiar with the old country towns of that section to which one must look for the typical aspects of New England life. Like all the sentiments of its people, the love of flowers is there, not paraded, but profoundly cherished; and if there is no gaudy display in the dooryard, there is sure to be found a corner behind the house, easily accessible to the kitchen, where old-fashioned plants bloom gayly, and are cherished often from some tender association with the past. Any country doctor in one of the older New England villages can tell these critics that there are almost no houses so homely, but that he finds in them, in winter, a few plants in the window, and in summer some bright flowers in a tiny garden, cultivated and watered often by feeble and tired hands. Hard and dreary as are many of the poor little lives of New England villagers, this one touch of color and perfume is there almost invariably, to show that the thirst for beauty is unquenched. 


\section{The Rescue of an Old Place}

New England loves flowers as well as Old England.

If, with its ungrateful soil and tormenting climate, New England cannot rival Old England in the gay surroundings of its cottage doors, the same love of flowers is there, finding such expression as it may, under the cruel conditions of a sterile earth, and burning summer heats and dryness, alternated with sharp east winds, which make a labor as well as a pleasure of a garden. 
XV

THE ROSE-CHAFER 
All the fields which thou dost see, All the plants, belong to thee; All the summer hours produce, Fertile made with early juice. Man for thee doth sow and plow, Farmer he, and landlord thou !

ANACREON. 


\section{XV}

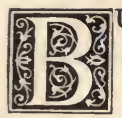

UT however much we New Eng- Our summer Tisitors landers may love flowers, there tread upon are drawbacks to their cultiva- heels.

tion in the pests that beset them. Each plant has its enemy, and there is no interim between our summer visitors. No sooner is the trunk of the last caterpillar packed than the rose-bug arrives, bag and baggage, to take his place. The half-eaten leaves that have been rescued from the jaws of the web-worm are in a few hours riddled with the bites of these winged pests, which are even harder to destroy than their predecessors, for they hunt in couples and fly, and cannot be stamped out of existence.

An imperturbable imp is the rosechafer, descendant on one side from the scarabæus; and if his Egyptian ancestor was half as hard to kill as this other flying beetle, no wonder the ancients used him as an emblem of immortality. 


\section{The Rescue of an Old Place}

That horrid rose-bug.

Arsenical poisons useless.

This voracious summer boarder arrives with unpleasant punctuality upon the tenth of June, - that is to say, the advance-guard of the great army shows itself in the shape of a scout or two, who merely precede the main swarm, which comes in a cloud, and settles everywhere, and stays nearly four weeks.

The opening roses are their nominal prey, and are soon disfigured with their dingy yellow-brown carcasses; but that is not the worst of them. Grape blossoms are their dear delight, and nothing but the most unremitting attention will save the future bunches from their greedy depredations. There are at least two to every raceme of fragrant blossoms, and by the time one has disposed of that pair, another is flying about all ready to take their places.

Arsenical poisons have no more effect upon them than a cold shoulder on an office-seeker. They may kill the plant, but never the rose-bug, which will crawl undismayed over its ruins, seeking new worlds to conquer. Having no delicate sensibilities, they are undeterred by whale180 


\section{The Rose-Chafer}

oil soap, which disheartens most things, They enjoy and even a dusting with hellebore does what.

not even make them sneeze. The great unterrified eat on, in spite of all you can do to them, and no sooner is one set slain than you find another in its place. They remind one of the Jesuit monks in Bolivia, whom the inhabitants finally regarded as supernatural beings, because, no matter how often one cowled and sandaled form was laid low, another succeeded it, till the natives came to believe that the friar was an immortal, whom they vainly sought to destroy.

As to the rose-bug, hand-picking into a bowl of kerosene or hot water, begun at Hand-picking the final morn, continued till noon, and not intermitted till dewy eve, is the safest resource against the marauders, which devour not only Grape blossoms and Roses, Spiræas and Syringas, Peonies and Snowballs, but cover Birches, Oaks, Elms, and even Willows with their ugly little forms, and leave behind them a lacework of veins in place of leaves.

Nothing pleases them better than a Smoke bush in blossom, the future fringe 


\section{The Rescue of an Old Place}

of which they will completely destroy in a few hours. We tried the experiment this year of tying ours up in mosquito-netting, but it seemed to accomplish nothing better than the excitement of the curiosity of passers-by, who could not make out whether it was a ghost on the lawn, or a balloon waiting for a Fourth of July inflation. The indomitable chafers perched on the outside by the hundred, and chewed at the blossoms through the meshes, so that, what with their attacks and the confinement, the smoke came to nothing after all, for when the cover was removed nothing was to be seen of the fringe but a few bare green stems.

The rosebugs find Overlea unhealthy.
Probably the rose-bugs do not publish a morning paper, or they would learn that the lawn at Overlea is an unhealthy situation for their race, and that their unprecedented mortality in that region ought to be a warning to them. Certainly in the height of the season the hecatomb of victims amounts to a thousand a day, but the cry is still, They come.

We hoped that the long, cold, easterly storm of June would prove a discourage182 


\section{The Rose-Chafer}

ment to them, but the minute it stopped raining they reappeared, more numerous They prefer old Roses to and hearty than ever, and made up nobly for lost time. They show a curious preference for old-fashioned Roses, and will devour them, leaving a bed of hybrids of modern varieties almost untouched, and they never are found here on the Tea Roses. They will eat the hardy $\mathrm{Hy}$ drangea voraciously, but do not affect the Weigelia. They spoil the Snowballs, but do not meddle with Lilacs. We have some young Canoe Birches that are struggling for existence, and I always imagine the departing caterpillar exchanging compliments with the arriving rose-bug, and recommending them to his particular attention, after the fashion of guzzling Jack and gorging Jimmy :-

Here's little Billee, he 's young and tender, They 're old and tough, so let's eat he.

Positively, if, during three or four weeks They devour the trees. of their stay, those insects were not fought tooth and nail, there would not be one leaf left upon those unhappy little trees. As it is, when the brutes depart, the 183 


\section{The Rescue of an Old Place}

Birches look like a design in skeleton leaves.

Sludgite. This year our hopes were roused by a remedy called sludgite, which was warranted to kill, not only the rose-bug, but the Colorado beetle and all other insects fatal to vegetation. Though scoffed at by incredulous friends, we dared to send for a can of this evil-smelling mixture, and applied it to the creature, with whom it undoubtedly disagrees. It is made of the residue of petroleum and soap, and smells to heaven, but, alas! the rose-bug has no nose, - at least no nose that takes offense at bad odors. Sludgite is a thick, semi-solid substance that mingles readily with water and is applied by a spraying pump or a hand syringe, and kills by contact. The rose-bug and the Colorado beetle keel over with all their heels in the air as soon as the gummy fluid comes in contact with their wing coverings, but, curiously enough, it seems to have no power to destroy the larva of the potatobug, and, not being a poison, it seems to have no deterring effect upon the little worm that eats the leaves of Rose bushes, 


\section{The Rose-Chafer}

or even upon the thrip, which whale-oil soap banishes for a long time. Therefore, I judge that the mixture clogs the wings, and interferes with the breathing of beetles, or, possibly, whatever virtue it possesses lies in the volatile essence which escapes from it, for the fresh mixture is much more deadly than that which has stood for some time.

But the sad thing about its use is, that The rosethe rose-bug is a being that draws no no moral. moral from any tale, and he is totally devoid of sentiment. I cannot find that the corpses of his relations take away from his appetite in the least. Possibly the numerous attendants we see at the funeral come for a wake, and they are full as hungry and thirsty as Conn the Shaughraun's cousins, on the same melancholy occasion.

Though I am disposed to think that the chafers may not be quite so ready to attack a bush or tree freshly anointed with the unsavory fluid, I am not sure but that the wish is father to the thought. In any case, it is not practicable to shower a bush every five minutes with anything, however

$$
\text { I } 85
$$


deadly, so that it is almost as discouraging as hand-picking.

Muscle worth more than faith.

A distinguished horticultural authority, who takes very little stock in my new discoveries, declares that muscle is worth more than faith, and shows me perfect roses, as large as his fist, to prove it. This is all very well if you are lucky enough to have unlimited muscle at your command, as in an arboretum for instance, where every rose-bug has a man to catch him, but both hand-picking and insecticides are alike failures in a private family with one factotum. What the world demands is a warning of some kind that the chafer who runs may read, a something to convey to his insect-mind or nostrils the information that " no rose-bug need apply," and whoso can make this discovery palpable to the enemy will have his fortune in his red right hand.

The legends connected with the rosebug are numerous. They tell us that he will not molest a Grapevine or a Rose bush close against a house, though he will devour the Virginia-creeper against the lattice of your veranda. He is supposed 


\section{The Rose-Chafer}

to object to the dust of the road and to a sprinkling of coal-ashes; but on our own windy hill neither of these deterrents can be made to stick.

Another legend belongs to the potato- $A$ legend. beetle, which some of the farmers in this neighborhood vow will not trouble potatoes planted in a hill with beans; but this is merely a legend. We have tried it, and find the creatures as lively as ever.

To return to sludgite, I would say that its highest practical use is upon trees and shrubs without blossoms, for the sticky yellow fluid cannot be sprinkled upon roses without spoiling their fairness. So far it does not seem to damage foliage, but we cannot answer for the effect of such a viscid decoction if used many times a day. We have never tried it more than twice in twenty-four hours. It kills or drives away the insects that are there, but others appear immediately, so that such insecticides are little better than substitutes for handpicking.

Our struggles with the hated rose-bug, and the hopeless nature of any prolonged encounter with an inferior organism of 


\section{The Rescue of an Old Place}

overwhelming numbers, find such clear expression in the words of a correspondent, that I subjoin an extract from a letter of a lady who has had similar sufferings with another insect :-

Fight with a srail.

"I am passing through the discouraging season of gardening, and am realizing more than ever the nature of Adam's curse. It sounds like a fine thing to be told we shall have dominion over the birds of the air and the beasts of the field, but what gain is there in that if we are to be beaten in the end by the angle-worm, the ant, and the snail? To fight with a snail, and be beaten, is n't that humilation? But I stand in the place of the vanquished, and it is the snail that has done it. I was born a sentimentalist, and had scruples about 'taking away the life thou canst not give,' that once hindered my career as a gardener. Now I grieve over the imperfect nature of the snail's nervous system that makes even death apparently painless.

" But he keeps up with the times, does the snail; he reads the seed catalogues, and he knows that Asters cost more than Marigolds; he has an eye for beauty, too; 


\section{The Rose-Chafer}

he knows a foliage plant very early in its career, and his taste is always for red rather than green.

"The snail is a much underrated power; The snailan his calmness, his persistence, his retiring power. nature, his thick-skinned endurance, make him a type that is bound to survive, and I predict for him a glorious future. If he can only find enough fools to cultivate gardens for his use he will enter in and possess the land, and develop into something quite grand." All of which quotation, with slight variation, will answer for our winged pest.

I was quite touched by the prediction The future of a member of the horticultural society $\begin{aligned} & \text { governor of } \\ & \text { New fersey. }\end{aligned}$ of that State, that apparently the whole of southern New Jersey will have to be abandoned to the rose-bug. This adds a new terror to the already complicated legislation of that unhappy region, for I am convinced, from my experience, that if the rose-bug wants anything he will get it, and no doubt we shall live to see him sitting in the gubernatorial chair. 



\section{XVI}

SUFFERINGS FROM DROUGHT 
In heat the landscape quivering lies; The cattle pant beneath the tree; Through parching air and purple skies, The earth looks up in vain for thee, For thee, for thee it looks in vain,

$O$ gentle, gentle summer rain!

W. C. BennetT. 


\section{XVI}

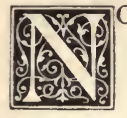

$O R$ are the insects the only plagues which menace our cherished gardens, and our carefully planted wood-lots; there are weather conditions that no vigilance can elude, which add tremendously to the difficulties of the planter of flower or tree.

On the south shore of Massachusetts Rainless Bay almost every summer sees a long period of rainless weather. The thunderweather on the South Shore. storms that gather portentously after hot days, are apt to drift away to the north, with only the tiniest sprinkling of our dusty roads and parched fields, to pour their wealth upon the crags of Swampscott and Lynn, Beverly and Marblehead. With jealous eyes we watch the rain descending upon our opposite neighbors of the North Shore, while we continue to dry up for want of it.

This period of dry weather usually beI93 


\section{The Rescue of an Old Place}

An excep- gins about the last of June and continues tionalseason. well into August, which is ordinarily wet and muggy, but the spring and summer of r89 I seemed disposed to defy precedent. April, which from time immemorial has been depended on for showers, this year completely spoiled its record, and only gave us an inch and a fraction of rain. This was followed by a dry, cold May, and then came the first half of June without a drop, culminating in two days the like of which we seldom see, the mercury touching ninety-seven degrees in the shade. Then, at last, down came the floods with a rush, and refreshed the parched and thirsty earth for days, the first continued rain-storm for three months, sorely needed by the suffering hay-crop and the dwindling trees.

During drought in this region, where the soil is light and sandy, the care of lawns and gardens has to be incessant. Fortunately our old town has a fine supply of aqueduct water brought from a nearly inexhaustible pond within its limits, and the hose can be brought to bear with effect upon the worst places; but this, 


\section{Sufferings from Drought}

like other restoratives, must be used with Necessity moderation. moderation. Too much water cakes the ing.

soil and draws the roots to the surface, so that, once begun, it must be continued or the plants die. It is better, we find, to water heavily two or three times a week than to keep up a continued sprinkling. If the water plays upon trees and shrubs during hot sunshine, the leaves are apt to scorch and shrivel, and the same is true of vegetables, which are well known to resent being watered on a hot day.

At Overlea the garden, which lies low along the edges of the meadow, can get along very fairly without watering. Even this year the strawberry crop, which is very sensitive to a lack of moisture, did not suffer from the dry weather, possibly owing to heavy mulching with straw while the ground was moist from showers. The worst of droughts in June is never so bad as the same dryness in July, for plants, which are then in fullest vigor, can better bear the strain upon their constitutions at that time; it gives them a set-back, however, which prevents a vigorous growth. Grass is the greatest sufferer, and the first 


\section{The Rescue of an Old Place}

hay-crop is often ruined by lack of rain, as was the case this year in our neighborhood. Our Catalpa Upon the sandy knoll where our house
suffers from changes in is situated, and especially along the street, in places only accessible to a very long hose, the trees and turf suffered greatly, and the sudden drop of fifty degrees of temperature, at the end of the period of drought, had a most disastrous effect upon the leaves, which shriveled and curled and turned red, and dropped off in many instances. A vigorous young Catalpa on our lawn, which, after the cautious manner of its kind, only ventured to put on its spring gown after the first of June, and then undertook to blossom freely, was so distressed by the changes of the weather, that after the storm we found at least two bushels of leaves strewing the ground beneath it, and many others in such a condition that the lightest touch would detach them. Enough remained, however, to protect the blossoms, which are wonderful productions for a tree to bear. If each one grew in a garden on a single slender stem one would value it for its exquisite 


\section{Sufferings from Drought}

painted beauty, and delicate perfume; and to find a great spike of them decorating a burly tree is a constant source of astonishment at the prodigality of Nature. It is like the appearance of a fine gentleman of the last century in a ruffled shirt and diamond shoe-buckles, among the more plainly coated fin de siecle beaux of our own day.

I have a great admiration for a Catalpa ; its huge vivid green leaves give it a semi- and the $\mathrm{Ca}$ tropical air, and its sensitiveness to cold and storm shows that it comes naturally from a warmer clime than ours. I try to console it for its exile by lending it in summer-time our Amazon parrot for a companion, and there is no prettier sight than the vision of this lovely green bird, of exactly the shades of the sunlight and shadow on the Catalpa leaves, pluming himself untethered upon the inner branches, only caged by the dome of the great boughs with their verdant canopy. When the leaves are in their prime he is perfectly concealed from view by his color, even when he takes a fancy to perch upon an outer bough; and there he mocks and 


\section{The Rescue of an Old Place}

jeers at the passers-by with songs and laughter and merry cries, till you would think a whole primary school was let loose upon the lawn and all the pupils calling each other by name, or else that this was a lunatic asylum.

Drought on the hill severe.
To return to the line of trees that border the street. We find that it is not safe to leave them without a heavy top-dressing to act as mulch, and this application having been delayed this year by press of business, we found one good-sized Elm, that we imagined to be settled for life, dropping its leaves and turning brown in a most unbecoming manner, while the smaller and more recently planted trees were also showing signs of distress. A good dousing and dressing brought them all to, however, and when the mowing of the swale after the rain allowed us to make the rounds of the plantation, we discovered that the only serious sufferers were our newly set Pines, which are bringing the hill into disrepute by their brown and sear condition. This eminence naturally suffers severely from drought and hot weather; the little Oaks and Chestnuts 198 
burn up, and the Pines wilt distressingly, but they are so numerous that there is nothing to be done for them but to await the survival of the fittest. An Oak once rooted is rooted forever, but it is a question of time as to when it can maintain its top, and ours have burned off year after year, until now they seem to have gained vigor enough to hang on in spite of fate.

Among the searching questions that are put to the members of the Society of Friends, in their meetings for the investigation of personal character, one of the queries is, "Has any Friend entered into business beyond his ability to manage?"

This question we are obliged to answer $A$ melanin the affirmative when we take time to choly confession of unask it of ourselves, for, having outlined thrift. work enough for a dozen men, it becomes a puzzle how to carry it on with only the aid of one factotum; extra hands being very hard to obtain in this village during the summer months. Much that we do is accordingly a makeshift. I am sadly obliged to confess to the existence of weeds where no weeds should be, of neg- 


\section{The Rescue of an Old Place}

lected spaces, of trees on the hill smothered by grass, of rose-bugs unslain, and caterpillars left at large ; of a struggle for general effect, rather than a realization of neatness in detail, all of which is most reprehensible and melancholy. We look at our neighbors' neat gardens with remorse and envy, and can only console ourselves by reflecting that when they are gone the weeds will have their way, but that in our struggle with nature in the end the trees will win, and trample the weeds under their mighty feet, and rear their stately heads proudly, while the beets and carrots of a future generation are still struggling with their yearly foes.

The weeds' days are numbered.

In a recent visit to the shores of the Merrimac, I have seen hills carpeted with the fallen leaves of haughty Pines that have numbered some centuries of growth, and I can smile at the flaunting Daisies of the hill, which overtop our baby evergreens, and threaten to exterminate them. Your days are numbered, $\mathrm{O}$ weeds! Wave now and dance in the sunshine while you may, for the first nails are being driven in your coffins. Little you reck that the 200 


\section{Sufferings from Drought}

small brown spines, that disappear at your $A$ rising roots, are the first drops of a rising tide that is to bury your bright blossoms, and strangle your weedy growth. For a few years to come you may preen yourselves upon the hillside, but the tiny seedlings below are rising higher and higher, wider spread their green arms, thicker falls the brown shower, which at first nourishes your gaudy uselessness, but at last shall arise and overwhelm it forever. The gay and trivial have their little day of sunshine and triumph, but the strong roots of serious vigor endure when the sunlight fails, and the winter winds blow. Everything in the lower is typical of the higher life, and the ephemeral for a time seems brighter and stronger than the eternal; but not forever. Though speed may tell in a short race, it is bottom that wins the long ones, and it is the patient who inherit the earth.

This is the great lesson of the forest, the The lesson philosophy it plants in him who nourishes of the forest. it and awaits its growth. In the faint rustle of the tiny leaflets I hear the murmur, "Wait!" and as I wander under the 


\section{The Rescue of an Old Place}

Wait ? shade of trees a hundred years old, I hear the echo far above me of that tender cry, in a solemn whisper: "Wait! They, too, shall be as we are, giants in their day. What matters it that thy little life will be long over? for thee the weeds and battle, for others the shade and rest. Plant thou ! that is thy mission, and the joy of him who reaps the fruit of thy labors shall be no greater than thine. Knowest thou not, O thou of little faith, that to look forward is the best of joys? Thy reward is renewed to thee daily in thy hope. Learn patience, and content thy soul."

Counsel of And so the young trees and the old the trees. alike, give counsel to him who can understand their language, whether he bends to listen to the soft voice at his feet, or lifts his head to catch the diapason of the overarching forest; encouraged by the lesson, we take up our burden anew - in our case the burden of a watering-pot - and do battle with the drought with a braver heart and sturdier resolution. 
XVII

THE BLESSING OF THE RAIN 
The garden trees are busy with the shower

That fell ere sunset; now methinks they talk,

Lowly and sweetly as befits the hour,

One to another down the grassy walk.

Hark! the laburnum from his opening flower

This cheery creeper greets in whisper light,

While the grim fir, rejoicing in the night,

Hoarse mutters to the murmuring sycamore.

What shall I deem their converse? Would they hail

The wild gray light that fronts yon massive cloud,

Or the half bow rising like pillared fire?

Or are they sighing faintly for desire

That with May dawn their leaves may be o'erflowed,

And dews about their feet may never fail ?

arthur Hallam. 


\section{XVII}

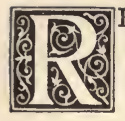

EFRESHING, indeed, are the long storms that succeed these burning days ; and it is a joy to Plant trees to make rainy weath.

see the thirsty grass and plants drinking in life with every drop. I am convinced that the true way to render yourself indifferent to inclement weather in the country is to plant trees. No rain can ever hurt them, and, when they are freshly set out, each shower is a satisfaction to their owner, for it seems as if they could be seen to grow under its kindly influence, and thus a day or week of hard rain, instead of a weariness, becomes a positive delight. I am not sure that this would bring compensation to the young for having to forego their active pleasures, but the more I become interested in gardening the more $I$ am convinced that it is the appropriate pleasure for middle life and old age. 
Gardening the pleasure of mature life.
Youth hates to wait for anything, and wishes to realize its dreams so soon as they are conceived; but as we advance in years we take a sober satisfaction in waiting a little for our pleasures, and also we like something that can recur, and that is interminable. Most other delights once experienced are exhausted, but gardening grows by what it feeds on. It is the same, and yet never the same; it can be forever renewed; it can be indefinitely extended; it is within the reach of all dwellers in the country, where home amusements are most needed. It can be compassed by the slenderest purse, and it will give a man a chance to spend a fortune if he so desire. It has its agreeable economies, and its fascinating extravagances. It can be made to satisfy the most orderly dispositions, and also return beauty and grace from careless and wild arrangements. It can be utilitarian and lucrative, it can be merely æsthetic and ornamental, or all four, just as the fancy takes you. In fact it may be briefly characterized as happiness for the million, with no patent on it. Added to all these charms is its whole206 


\section{The Blessing of the Rain}

someness, its absorbing character, and, Its humanbest of all, a certain humanness about the ness.

occupation that brings one into pleasant relations with all sorts of people, and affords one a topic of conversation and a meeting-ground, even where he is limited to the most unpromising companions. The village crone forgets her gossip when you talk to her about her Rose bushes, or her last new Geranium slip; the farmer waxes eloquent over the merits of a new potato, or a way of protecting melons, and you find yourself always interested and instructed, instead of bored, since almost any one you meet in the country can tell you something you are glad to know; or else he is eager to learn what you are doing yourself, which is a sure way to afford you entertainment, since every man is happy when allowed to ride his own hobby. All of which has a connection with rain, however little obvious it may be, since the moral of my discourse is, that when one becomes not only resigned to rain but glad of it, he has taken a step toward true philosophy.

A garden after a shower has always an 


\section{The Rescue of an Old Place}

Beanty of a especial charm ; everything is sweeter and gardenafiter
a shower. dition. I have a passion for dabbling in water-coloring of this description, and cannot keep my hands from the weeds and flowers, when I venture forth to see how my favorites have borne the storm. It is a delight to put one's arms about a bouncing peony, with its red cheeks all cold and dripping, and tie a string around it to keep its bright faces clean. The forward flowers kiss you as you struggle to encircle them; the wet leaves box your ears, as if you were taking a liberty. It is some time before you can accomplish your purpose, and you arise from the encounter quite breathless and dripping, with the pink and white faces, huddled up together, all laughing at your condition.

It is June, and the last of the Fleur-de-lis are quite broken down, their pearly petals draggled in mud and defaced by water. This delicate French beauty will put up with no plebeian touch, but withers and dies if brought in contact with the earth. The Roses stand up, after their bath, quite fresh and shining, but the buds, which are 208 


\section{The Blessing of the Rain}

so blighted by a heavy rain that they do not open afterward, remind me of the Austrian violinist in "A Week in a French Country House," who greatly admired an English beauty, but confided to a friend his reason for not offering to marry her :"She vould vash me, and I should die."

Many things are broken down and require tying up. If the rain has continued for several days the chickweeds are rampant, and overrun everything. New plants that have been on the anxious seat during the dry weather have decided to stay, and are putting forth satisfactory leaves.

The joyful Pear-trees shake their drops down upon you, the cat-bird sits on the The cat-bird converses. grape trellis and inquires what you are doing there. It is a way he has. He lives in the Box arbor, and thinks he owns the earth, and that our strawberries are his. He scolds the cat, and defies the robin, and has such a trig, gentlemanly air about him, with his well-brushed dark coat, that one might christen him Sir Charles Grandison. He makes me a bow, and says civil things (or uncivil) in his own tongue, 


\section{The Rescue of an Old Place}

which, unfortunately, I do not understand.

"I thought you told me this parrot could talk?"

"So he can - ze parrot lankwich you don't expect all ze lankwiches for ten tollar, do you?"

Thus our cat-bird, which costs us nothing but strawberries, discourses in a jargon which we would fain comprehend, so as to answer him according to his deserts; and sometimes of a Sunday morning he sings us a glorious tune.

Apollo the parrot in

When the rain comes, Apollo, the parrot, climbs to the top of the tree in which he is perched, and spreads all his bright feathers to catch the shower. Elongating his wings, he makes them meet over his brow in the very attitude of the cherubim, and then, turning a somersault, he hangs head downward, that the water may thoroughly drench his plumage. With all his gold, and red, and green glittering with raindrops, he resembles some superb blossom quivering on a stem, and makes a beautiful spectacle of himself. When his bath is done he chatters and laughs 


\section{The Blessing of the Rain}

with glee, and sings his merriest song, with some disregard of rhythm and tune, but none of harmony, till all the smaller birds begin to pipe in company.

The dusty foliage emerges brilliantly New birth shining and fresh. Every shower seems rain. to bring a new spring, and the world never fails to be surprised at the renovation which succeeds the rain. There seem, indeed, to be new heavens and a new earth. The drooping evergreens lift up their tasseled heads and take courage; to them it means life and new hope. The vines throw out their tendrils, and the Honeysuckle emits a keener perfume. The white Lilies that come to rejoice us just as the Roses are going, gleam in the twilight, tall and fair. Who falsely says that it is merely a license of the poets to mingle Roses and Lilies, since they do not blossom at the same time? With us the Irises and the white Flower de Luce linger till after the Roses are in bloom, and then, before the queen is wholly out of sight, come these stately princesses, her followers, like The flower princesses. train-bearers of high degree, all clad in white and gold, nearest the throne, if not 
rivals for the : ighest place of all. Is it the thorns that make the Rose the royal flower, by rendering her difficult of access, and surrounding her with a bodyguard of lances? Who shall say? There are moods in which her sumptuous beauty and heavy fragrance seem less regal than the haughty, willowy grace of her rival flower, and we hesitate to choose.

Mistaken

And not the flowers alone rejoice in the life-giving drops, but the "sweet smale grass," refreshed and strengthened, lifts its green blades like the spear-heads of a rising army. The dusty mantle that has veiled its gentle beauty falls from it, and the wonderful variation of its tints again delights the eye. Those artists who set our teeth on edge with verdigris and arsenic floods, to represent this dearest and homeliest garment of our mother earth, seem to me never to have entered into and possessed its secret, - the secret of myriad shadows, of myriad lights, each catching a reflection from its neighbor blade, the brown earth below, the azure sky above. No greenest green of foliage or meadow ever shocks the most sensitive 


\section{The Blessing of the Rain}

vision, for Nature, truest of painters, never Nature is fails to break her colors with such subtle the one true mixtures, that only the utmost training of eye and hand enables the artist to hint her secret upon canvas; and he who, with a palette of crude pigments of raw primary colors, seeks to render the shifting emerald of spring, the topaz of the newmown field, or the gold of harvest, is as one who would catch the flash of the diamond, or the burning heart of the ruby, on the brush's point, and think to imprison it forever.

There are some lines of Matthew Arnold that a wet garden always brings to mind, in which the poet has truly caught the spirit of the fragrant scene. None but a frequenter and true lover of gardens could, in a few words, have thus pictured the mingled dismay and hope with which one views his garden-plot after a rain has both distressed and refreshed it :-

So, some tempestuous morn in early June, When the year's primal burst of bloom is o'er,

Before the roses and the longest day When garden-walks, and all the grassy floor With blossoms, red and white, of fallen May, And Chestnut-flowers are strewn - 


\section{The Rescue of an Old Place}

The garden in the rain.

So have I heard the cuckoo's parting cry,

From the wet field through the vext garden trees

Come, with the volleying rain and tossing breeze;

The bloom is gone, and with the bloom go I !

Too quick despairer, wherefore wilt thou go ? Soon will the high Midsummer pomps come on, Soon will the musk carnations break and swell, Soon shall we have gold-dusted snapdragon,

Sweet-william with his homely cottage smell, And stocks in fragrant blow;

Roses that down the alleys shine afar, And open, jasmine-muffled lattices, And groups under the dreaming garden trees, And the full moon, and the white evening star.

\section{4}


XVIII

DISCOURAGEMENTS 
Even now the devastation is begun, And half the business of destruction done.

GoLDSMITH.

$O$ rivers, forests, hills, and plains I

Oft have ye heard my cantie strains;

But now, what else for me remains

But tales of woe?

ROBERT BURNS. 


\section{XVIII}

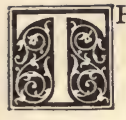

HERE are other things beside drought to depress the spirits Gardening of the planter, who has often reason to wonder why he entered upon his disheartening career.

It was, I believe, Sir George Cornewall Lewis who declared that life would be a very enjoyable thing were it not for its pleasures, which is convincing proof that he must at some time or other have interested himself in gardening, since this pursuit, which at first seems, of all others, the most gentle and enticing, leads the unwary dilettante from woe to woe before it has done with him.

As soon as our forest is tall enough to show above it, we are talking of erecting an arch at its most obvious point of entrance, with the appropriate inscription,Abandon hope, all ye who enter here !

our experience leading us to think that 
the only way to enjoy a prospective wilderness is to find one's blessedness in being among the happy few who expect nothing, and therefore can never have any but agreeable surprises. This arch, which perhaps will more appropriately take the form of a lich-gate, is to be sculptured with high reliefs of the woodchuck and the field mouse, while the rose-bug and the wire-worm are to find a prominent place in the general decoration. This architectural step has been suggested by the appearance of a new enemy, which has destroyed the last vestige of our confidence in conifers, and is a new proof of that perversity in trees to which I have before reluctantly called attention.

Trouble among the Pines.

Early in July we noticed a tendency to droop in the leaders of some of the Pines and Spruces, but concluded it might be the dry hot weather which had affected their uprightness. A week or two more passed, and the new tassels of the year's growth all began to turn yellow, and to hang down disconsolately. We then supposed that some one in passing might have given the tops of the little trees an 


\section{Discouragements}

unfriendly twitch, from which they were suffering; but as the days went by and a Trees in trouble. stout little Norway Spruce near the house began to lose its topknot, and Episcopus himself showed a bad droop in his mitre, we thought it worth while to look into the matter more closely, so we chopped off the head of one of the sufferers, and gave it a post-mortem examination. Dissection revealed ravages, and the fatal secret was out. There was a worm at the core!

And not one worm, but many, - small, white, plump and persevering, indifferent to resin, and coolly tunneling their way down the inside of the stem toward the ground. Certain leaks on the outside, and port-holes of their own construction, showed the exact length to which they had gone, so that by cutting just where these signs disappeared, we had the satisfaction of ending the earthly career of the leading invader, by snipping his fat unpleasant carcass neatly in two.

We pursued our insidious foe from tree An insidious to tree with the shears, and beheaded him with great slaughter. But, alas! it was only a realization of the old nursery sneer, 


\section{The Rescue of an Old Place}

about cutting off your nose to spite your face, for when we had decapitated the worm, we left a headless tree to serve as his monument, and, in some cases, the wretched little monster compelled the destruction of three years' slow growth.

The parent of the worm, being a fly of ambition and taste, invariably picked out the biggest and showiest of the poor little struggling trees to lay her eggs in, so that after the day of judgment was over, and the ins(ect)urrection crushed, our pride was crushed with it, for the borer, not being, alack! the baseless fabric of a vision, left an awful wrack behind, both of our Pines and our vainglory.

Small comfort do we find in the assurance that the Pines will be none the worse for topping, for, with a life and trees so short as ours, "a few years" are not to be lightly regarded, and the poor hill had precious little good looks to lose, and has been waiting for its beauty already quite long enough. Moreover, what assurance can we have that every summer will not bring with it fresh devastation? It takes a year or two for insects to find you 


\section{Discouragements}

out; but their first call is never their last. If the borers have intelligence of the existence of Pines on "Doctor's Hill," they will come again as sure as the tax-collector, and new woes are in store for us from their visitations.

Moved by that desire to find consola- Norway tion in our neighbor's ills, to which La fering from Rochefoucauld cynically alludes, we go the borer. about spying at the tops of other people's evergreens, and find that this is the borer's year. Driving, a few days since, in a neighboring village, I saw, with concern, a long row of tall Norway Spruces at least forty feet high, that inclose a public garden, all suffering from the attacks of our fell marauder. Luckily, their tops will hardly be missed, while ours - Wae's me! as Carlyle would moan.

Now the question arises, Is there any prevention as well as cure for this infliction? Is there any application obnoxious to the borer's mamma that can be put where she would lay her eggs, and so induce her to move on? Has she any avowed distaste for whale-oil soap, or coaltar, or kerosene emulsion, or any other un- 


\section{The Rescue of an Old Place}

pleasant odor? And if there is such a deterrent, where should it be applied on the very top of the leader, or at the place where the new shoots start from the old year's growth?

Dangerous moral tend. encies of gardening.

When a person sets out to plant a tree or two he scarcely bargains for having the study of entomology thrown in, with a course of chemistry into the bargain, not to mention toxicology, and the trade of wholesale murder, until he might as well begin the career of gardener by serving an apprenticeship to the Czar of Russia. I am horrified by the bloodthirstiness developed by this seemingly innocent diversion; still, this but confirms the view of pleasures before quoted. Indeed I am not sure but there is an opening for an essay on the Dangerous Moral Tendencies of Gardening. The only objection to it is, that if the Legislature of Massachusetts got wind of such a thing it would pass a law which might prove inconvenient. There are advantages in having your morals legislated about by a paternal, not to say puritanically paternal, government, but there are drawbacks also - one does 


\section{Discouragements}

not always wish to be virtuous by act of Parliament. Still, if the legislation can be brought to bear upon worms, we will not complain.

An eminent Philadelphia physician, visiting Boston, was struck with an inscription in the Public Garden, "Dogs forbidden to swim in this pond on Sunday," and remarked that he knew that education had been carried to an advanced stage in Massachusetts, but he had not learned before that even the dogs had been taught to read! How delighted we should be to learn that the gypsy moth has been warned off by the General Court. So far we of the South Shore have been left to cope, somewhat ineffectively, I admit, with our own insects, but if the famous moth finds us out we may expect the government myrmidons at its heels, and let us hope that they will carry the web-worms with them. But a commission ramping about the fields, even for so praiseworthy a purpose, has its terrors.

Another discouragement comes in the The saw-fly. worm which saws off the small branches of the Oaks, and leaves the ground strewn 


\section{The Rescue of an Old Place}

with twigs, as after a storm; but that supercilious insect disdains trees the size of ours, and he is still to be anticipated.

Upon some of the dwarf evergreens we have discovered a white scale insect, something like a mealy-bug, which covers the trunks and branches with its white spots, but that seems to yield to the dissuasive effects of soap and water, and disappears after a good scrubbing.

A Brobdingragian visits us.

The Hemlocks are to be watched with a new anxiety, since the newspapers tell us of a worm that is destroying the foliage and killing the timber in Potter County, Pennsylvania. This creature infests the trees in great quantities, to the dismay of the lumbermen, who are unable to destroy them. It is hard enough to persuade a Hemlock to grow, any way, but if a beast is lying in wait to devour it, we may as well give up altogether. I am told that there is a book as big as the Bible, published by the Agricultural Department in Washington, about nothing in the world but the insects injurious to forest-trees, which seems enough to discourage the planters, even of a wood that can be cov- 


\section{Discouragements}

ered by a pocket-handkerchief, like our $A$ giant own; but, to crown all, we rashly took a pygmies. Brobdingnagian in the tree-line to walk in our Lilliput one day - a Brobdingnagian to whom the largest Elm in Hingham is but a walking-stick - and, looking down upon our three-inch Oaks, he complained that there were not trees enough! Lucus a non lucendo - fancy a forest with that deficiency! Having, moreover, discovered that our favorite Beeches were Black Birches, he contrived to impress us with the fact that the best of our forest was the prospect, and that, when the trees were grown, we should not even have that! That Brobdingnagian was a terror! Luckily he had not much daylight to see the place in, or we should never have the courage to go on, for wherever we had a good-sized tree he advised that it should be cut down, and if there was a square inch of territory without a seedling he thought it would be a good plan to put in a handful; and he even showed a disposition to discredit our crack story about a yield of forty bushels in the palmy days of our great Pear-tree, Methusaleh, but 
that may have been because we tried to make him believe they were barrels.

He takes

So much for taking a Man-Mountain tribute. into Lilliput. I would not have trusted that one alone upon the premises with a pair of scissors, for there is nothing less to be depended on than the cutting mania. Granted that one ultimately accepts the situation, the moment when your tree comes down is always one of anguish. It takes so long to grow, and is so easily dèstroyed. Our Brobdingnagian took his toll at last, for he pointed out the fact that the flourishing little Elm I have been cherishing to shade the seat in the Box-arbor from the noonday heat, was really injuring the Box and should come down, which it did forthwith, as a tribute to his superior knowledge, - a nice tree, too, that it would take ten years and more to grow again.

$A$ vista in-

We have another disturbing visitor who sisted upon. insists upon a vista, which involves the sacrifice of a fine clump of Lilacs and Buckthorn, that shuts off a view of the northern part of the place. We are disposed to think that it would be an im- 


\section{Discouragements}

provement to get a glimpse of the great Elm-trunk and the green grass beyond; but, suppose we do not like it when the bushes are down, what then?

Even given on his part the best artistic perception, does it follow that another man's views of what you ought to like always suit your own?

May it not perhaps be wiser to work The contraout your own problems in your own way? riness of hu-

Human nature is so constituted that it yearns for authority, and when it gets authority it chafes thereat, and each man cherishes his own unwisdom as dearer than the knowledge of another. Such contrary beings are we that it is always what we have not that seems the greater blessing, and we seldom know when we are well off. The hardest state of mind to attain is content, and so little do we know the essence of happiness, that finding the contented man, we forthwith compassionate him for his lack of ambition, or gird at him for supineness, and pride ourselves upon our own divine unrest.

Even thus do the educating influences of the garden lead us round to philoso- 


\section{The Rescue of an Old Place}

phy, and the vista through the bushes opens out a moral perspective.

Solomon's trials.
It is only by what we suffer that we learn what is worth while, and, judging by the amount of suffering our amateur gardening gives us, we ought in time to have the wisdom of Solomon, which, ranging from the Cedar of Lebanon to the Hyssop on the wall, must have given him a good deal to undergo. No wonder that he discovered that "all is vanity." Probably it was borne in upon him by finding a borer in his own pet Cedar, or a caterpillar crawling over the remains of his last Hyssop.

We, struggling along after that illustrious gardener of Israel, have at least mastered one lesson, the important one that Nature, the rudest of task-mistresses, takes pains early to impress upon her pupils, sternly reiterating, -

I teach by killing, let the others learn!

228 
XIX

A WATER GARDEN 
Little streams have flowers a many,

Beautiful and fair as any;

Typha strong, and green bur-seed;

Willow-herb with cotton-seed;

Arrowhead with eye of jet,

And the water violet.

There the flowering-bush you meet,

And the plumy meadow sweet,

And in places deep and stilly,

Marble-like, the water lily.

MaRy HowitT. 


\section{XIX}

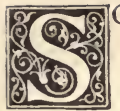

long as our friends profit by our mistakes, and gain the rea compensation for our failures; but let me give this bit of advice to the would-be gardener : if one is unable to secure ample assistance, and is obliged to develop a place slowly, the order of planting should be trees first, shrubs second, flowers last of all.

Trees may be considered as the skeleton, the framework upon which the whole scheme is constructed, giving it strong substantial outlines and decisive meaning. Shrubbery plays the part of muscles and flesh, covering the unsightly bare places, rounding out the form, supplying the essential, and giving grace and symmetry to the inclosure; while flowers may be regarded as the clothing with which the completed body is finally adorned. Naturally, one 


\section{The Rescue of an Old Place}

cannot resist sticking in a few flowers as he goes along, but their disposition is not final, and they take up a deal of time, and are, consequently, to be relegated to a subordinate place at first, and looked forward to as the occupation reserved for those future unemployed hours when the woody plants can be left to grow, and fulfill their mission.

Here, where the watering during summer, and frequent digging about and topdressing, to retain moisture, are absolutely essential to trees and shrubs, flowers that have to be weeded and tended are much neglected, and only those hardy perennials that will take care of themselves and defy weeds, have as yet any kind of a show. But we are always dreaming of a period when the ligneous plants can be let alone, and we can turn our attention seriously to the purely ornamental.

In the mean time, such wild things as come up of their own accord, on the hill and in the meadow, are full of interest, particularly in early spring and in late August, when the stock of hardy gardenflowers runs comparatively low. 


\section{A Water Garden}

At the latter period the little spot that Frogs in the

I call my water garden is really quite a water gar-

I call my water garden is really quite a den.

sight for such a humble affair, a mere mud-hole as it were, formed by a spring at the foot of the hill, which makes a tiny frog-pond, about ten feet or less in diameter. The frogs themselves are quite ornamental, wearing, as they do, the most gorgeous yellow and green coats, and being quite sociable and friendly, ready to sit on a chip and croak when we pay them a visit, and making music for us in the spring before the birds are fairly abroad. The old bull-frog, with a hoarse cold, is not always a comfort, for he has a way of coughing at night, like an asthmatic old gentleman, that is sometimes distressing, if you lie awake to listen, for it makes you sure his family must be anxious about him; but the piping little ones have quite a cheerful note, which blends agreeably with the chirpings of the grasshoppers.

On the marshy banks of the little pool, which cannot comfortably be reached without overshoes, some slim Willows are bravely growing, which I fear will some day make it too shady for the flowers, but 


\section{The Rescue of an Old Place}

at present they serve to give the spot a cosy and protected air, and the sunlight shifts through the light foliage, and falls kindly on the bright group of blossoms that make it so gay at the end of summer.

Wild foneers in the pool.

The pool is close to an old gray fence, over which the wild vines clamber, and against which the Milkwort, with its stiff stems and smooth leaves, stands up erect, its panicled pink blossom a-top; not a very choice plant, but a sturdy one, and the vivid color "carries" well against the green, and composes agreeably with the masses of Arrowheads that are at this season full of blossoms and tall-stemmed sharp leaves, like a group of Amazons with their shafts drawn to the ear.

At the edge of the pool a mass of sedges has been left unmown, and here are clumps of the creamy blossoms of the wild Foxglove, mixed with all sorts of Goldenrod, and some budding Asters, while the flowers of the Grasses are themselves beautiful and various in their own quiet way, some with plumes and some with spears, as if ready to oppose the Arrowheads. 


\section{A Water Garden}

The wild Caraway and the Yarrow show white among the grass, and there is a wonderful rosy hue in the tall spikes of Dock that are blooming near by. The Forget-me-nots are still full of blue blossoms, and spread out into the water far and wide, the earliest to come and the last to go of all the simple ornaments of the water garden.

But the glory of the pool is the Cardinal-flower, of rich dark red, which lifts $\begin{gathered}\text { bulbs a fail- } \\ \text { ure. }\end{gathered}$ its bracted racemes proudly, and with the dignity of a true hierarch. This shows to advantage for the first time this year, having before fallen a victim to the careless scythe, so that its blossoms, which it persisted in putting forth in spite of discouragements, were only a few inches high. But this summer no mower was allowed to come within six feet of the spot, and we are well rewarded by the glow and stateliness of this superb flower, which would be an ornament to the proudest parterre. The Water-lily bulbs that we got from a nursery in the spring have proved a failure, whether because they were planted too deep in the mud or be- 


\section{The Rescue of an Old Place}

cause the bulbs were defective, it is impossible to say. It may be that the spring is too cold for them, and that they require the warmer water of a pond; but they should not be difficult to raise, for I saw a pink Water-lily blossoming this summer $A$ rocky in a rocky pool, with nothing to grow in but the ball of rich mud in which it had been tightly packed before being gently laid in its stony bed. The picturesque pool is a feature of a small terraced garden, built out from the rocky side of a steep hill that descends abruptly to the seashore of Massachusetts Bay. The terrace is approached from the level on which the house above it is built, by a rough stone stairway, that has for a balustrade a huge granite boulder, overgrown with Ivy, and surmounted with trees. Great rocks inclose the terrace on three sides, and down the almost perpendicular face of one of them trickles the thread-like stream that falls into the pool below. The overflow wanders away in a small grassy channel, along the edge of which tiny water-plants grow, and Cardinal-flowers blossom. In the basin a pink Water-lily 


\section{A Water Garden}

is blooming, dainty dweller in a fairy home, and somewhere in the shadows a goldfish has a lurking-place. On the stone curb a blue jug, and a Japanese drinking-vessel formed of a shell, with a handle of bamboo, give the requisite touch of human needs and uses to this lonely dell.

The little green-turfed terrace is encir- A tiny tercled with flowers that thrive in this warm race. nook, where the morning sun shines hotly, and where its southwestern rays are tempered by the shade of great forest-trees. So steep is the hill that the shining waters of the ocean are seen through the topmost branches of tall Oaks and Hornbeams and Pines, while others stand far below. The brown seedy spike of a Dock-plant hangs out against the lichened crag, and forms a spot of rich color amid the prevailing gray, while all about, from crevices in the rocks, and from shady recesses beneath them, spring Ferns and Grasses, with wild flowers and picturesque weeds. Some young Sassafras-trees, or rather bushes, near by, which have sprung up of their own accord, have a particularly pleasing effect with their yellow-green 


\section{The Rescue of an Old Place}

A pictur-

leaves, and down the face of the rock esque vine. straggles a Blackberry-vine, as perfect in outline and graceful in sweep as if it had been drawn by the hand of a Japanese artist, each cluster of finely serrated leaves having a distinct value against the mottled stony background, which also gives a fine relief to the groups of flowers and ferns that cluster at the base of the pool.

In such a situation nothing showy should find place, but only those things which might naturally grow around a forest-spring. The little Cresses along the brook, the tender Forget-me-nots, the fine small Grasses, the water-weeds and ruby Lobelia, that have been wisely set here to enjoy the moisture, add to the wildwood charm of the pool with its tinkling water.

A. Fapanese Taste has gone hand in hand with nature and produced a lovely picture, delicate in detail, fine in color and grouping, harmonious in general composition. Minute the space is, almost, as a Japanese garden, but the effect is dignified and poetic. It is not mere prettiness that charms, but the true artistic feeling with which the idea has been conceived and executed. 


\section{A Water Garden}

The little scene touches and captivates, while gratifying all the senses with sound and sight and color, and soft touch of ocean breezes and of waving leaves.

Another feature of the picture is a $A$ second second semicircular terrace below, with Clematis-clad wall, to which one clambers by another flight of steps hewn in the rock to find more flowers, and more lovely weeds and grasses, and a second space of well mown turf, with a fine outlook on the tossing sea. From this a rugged path leads by devious ways to the beach below, where are boats and a yacht riding at anchor, and the wide stretch of the great deep, with white sails upon the surface and whiter clouds overhead. These terraces form a bit of artistic naturalness that would enchant even a critic from the Flowery Kingdom, and they were the re- Result of a sult of a charming woman's skillful plan- taste. ning, and fine sense of the picturesque.

But, returning to our own water garden, we find higher up the bank the Hawkweed showing its yellow stars waving on slender stems, and the Prunella displaying its stiff blue clusters, while more Asters 


\section{The Rescue of an Old Place}

blossom, and tufts of Goldenrod cling to the hillside, and entice us to a climb among the Pines.

Here we find that the dry summer has made havoc. Of thirty-five planted in April we shall barely save a dozen. This is discouraging, but we have gone bravely to work to set some more, and try whether August skies will be more propitious in the way of rain. We have also put in a few Savins, though we hear they take unkindly to transplanting.

Condition of The little Oaks and Maples have the trees on the hill. thriven, and are showing green against the already withering grass. The soil is yearly improving by letting it lie fallow, and the foot sinks into the soft cushion the uncut hay is making as a covering for the sand and gravel. If it were not for endangering the seedlings, quite a crop could be harvested. It is not soil the hill lacks so much as rain; but the long drought parches and distresses the plantation, and will do so till the trees can shade the ground and preserve its moisture.

The small Chestnut group of which I boasted in the spring has made very little 


\section{A Water Garden}

progress, and hardly looks larger than it our Chestdid last summer. Insects injured the nuts. early growth, and there was no later growth for lack of rain. But the trees are alive and healthy, so that we have something to be thankful for. Our one Mulberry-tree bore fruit plentifully, but failed to make much leaf-way. None of these trees were either top-dressed or watered, or they would have done better. It is impossible for us to keep everything in high condition, so that we must content ourselves with the slow progress that nature affords when unassisted. It really seems as if sunshine and water are the prime essentials, and that feeding is not half so important as drinking. With this view, it is hard to understand why it would have upset the economy of nature to have a shower every night in summer, to refresh the fields and gardens of the world. Possibly in time, when the new system of producing rain has been brought down to a fine point, there will be twice a week in villages a pyrotechnic display, accompanied with explosions, that will transform 


\section{The Rescue of an Old Place}

the year into a perpetual Fourth of July, to the delight of the infant mind.

Man cannot interfere with nature with imponity.

Seriously speaking, should this new enterprise prove successful, what a revolution man is to produce in nature! To trust such powers to his pygmy hand is dangerous, for the consequences of his personal gratification may be fatal to millions. Fertilize the Desert of Sahara, and you cool off the south of Europe. Alter the temperature of Spain and Italy and southern France, and what is to become of the British Isles ? It may be that thus the future of the Dark Continent is to be fulfilled. Migrations southward may begin. Norway and Sweden, like Greenland, may be left principally to the inferior races, while new colonies spring up in lands now tenanted but by the wandering Bedouin or the swarthy Soudanese.

Given new conditions, results are incalculable, and if the rain, as well as the lightning, is to be harnessed to the Chariot of Man, who can tell what disaster shall await the Phaeton who dares to drive such mighty and resistless steeds? Shall he too be hurled to ruin as a punish. 
ment for his overtopping ambition? or shall man will he prove master and lord even of the rule the elemental forces from whence he came? What is most sure is, that before they yield themselves wholly to his bidding he must suffer the consequences of his rashness, and win his way to control only by ghastly sacrifice of human life. 



\section{XX}

LANDSCAPE GARDENING 
Therefore am I still

A lover of the meadows and the woods

And mountains; and of all that we behold From this green earth; of all the mighty world Of eye and ear, both what they half create And what perceive.

WORDSWORTH. 


\section{$\mathrm{XX}$}

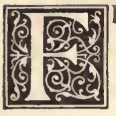

ROM unrelated detail upon a $A n$ idea place, we are gradually led grows out of towards broader effects, and a desire for more simple relations of parts to the whole, while a wish to bring subordination to some central idea that shall give purpose to the picture is gradually born in our minds. Thus our work becomes an education in the higher principles which must underlie all beauty.

When we first purchased this old farm A quiet vilno dream of landscape gardening crossed lage home. our minds. It was not to found a country-seat that we bought it, but simply to get a place to live in, a quiet village home, as indeed it is, where a lovely view would gladden our eyes, where we should have elbow-room, with enough land to cultivate to provide us with an interest, and where we could raise hay for our horses, and, 


\section{The Rescue of an Old Place}

perhaps, a few vegetables for ourselves. A tree or two to shade us, and some Pines on the hillside to relieve its dreariness, were in our programme, as well as the Willows along the street; but we felt that we had twice as much land as we needed, and should probably part with a lot on each side of us before very long, instead of wishing, as we now do, for a few acres more.

As in everything else that one begins in an amateurish way, we looked no further along the road we are to travel than the end of its first enticing curve, and little we recked where it was to lead us. To get rid of barrenness was our obvious business, but there was no method in our endeavor beyond the mere putting in of all the trees and shrubs we could muster from the resources of the place, or through the kindness of our friends.

Mistakes in the planting of trees.
For the first two years it required our best energies to make these live, and there was not much thought beyond digging around them, watering them when dry, and pruning them into shape. But the third summer, when the bare poles began to 248 


\section{Landscape Gardening}

have perceptible tops on them, and the little shrubs to occupy a substantial space of the earth's surface, we began to be conscious of defects of arrangement, of a lack of meaning and purpose in the picture, and to feel the necessity of a more artistic disposition of our forces. The needs of the place, too, became apparent. The trees that had been planted for shade either showed that they would throw no shadows at all within the next ten years, at the proper hours, or else would throw them where they were not particularly needed. The shrubs in groups looked crowded, the single ones gave a spotty appearance to the lawn that was not to be borne, the driveways were too wide and their curves unsatisfactory, while the expanses of turf were too brief for beauty.

Each effort at improvement seemed but to make us the more conscious of our lacks, and while our neighbors were complimenting us upon the improved appearance of the farm, which no longer looked like an abandoned sand-hill, we ourselves were taking counsel together, and coming to the conclusion that the place was a 


\section{The Rescue of an Old Place}

schoolmaster to bring us unto knowledge, by the painful road of ignorance and failure. It is a hope- The conviction that you know nothing
ful signto to be convinced is always a hopeful, if a depressing sign. that you know nothing.

When the painter feels that his finished picture is a wretched daub, when the writer knows that his last romance is but a thing of shreds and patches, it is a proof that he is still growing, that he has a stronger note to strike, and that his end is not yet.

One of our leading novelists says that his stories are to him like those tapestries wrought by the workman from behind, of which the weaver sees only the wrong side, the knots and ends of the worsted, the seams of the foundation, so that when the public views his finished work with delight, recognizing its sincerity and dramatic truth, the satisfaction of his readers is to him a wonder, since from his own point of view he knows not whether he has wrought well or ill.

Successes are surprises.
All great successes, I fancy, must be surprises to the men who make them, for the discontent of the artist with his paint- 


\section{Landscape Gardening}

ing, of the poet with his verse, of the The poet playwright with his play, is a penalty ex- and the acted by the ideal for which men strive, and which all the more surely eludes the greatest, whose imagination is the most far-reaching. When a man is satisfied with what he has done he has reached his limit ; from that point he goes down-hill, imperceptibly it may be at first, but none the less surely.

Our own discontent with our landscapegardening convinces me that we have a future before us for a good while to come. Our picture will bear a lot of working on for many years yet, and in the mean time we have room for a succession of despairs, which will serve to keep us properly humble.

But that we have on the north of our A landscape house a landscape to evolve that is a true puzzle. picture, no one can deny who looks out upon the ever-changing meadow from the bowery veranda from which we view it with never-failing joy. Not a far-reaching view, but such a one as Englishmen like to paint, a distant hill, a few clustering cottages, a level stretch of meadow with a 


\section{The Rescue of an Old Place}

A present muddle.

winding stream; some Willows near at hand. So far, so good; but the foreground is the puzzle. It is a muddle at present, being a sacrifice to the utilities, and is more or less disfigured with fruittrees and vegetables, and piles of sand that have been dumped upon the marsh. A good deal veiled it is, fortunately, by the bending boughs of Pear and Apple trees laden with fruit, which is their plea for life, and when one is seated the balustrade of the veranda is an efficient screen, so that one can freely enjoy the pleasing prospect.

The French talk of the St. Martin des femmes, which comes to them after the beauté du diable has long gone by; and our meadow, too, has its fleeting glory of youth in early spring, with Apple-bloom flush, and delicious verdancy to match, and then, after a commonplace summer of good looks, it comes to its Martinmas, and burns, and glows, and smiles, with a richness and warmth that are the precursor of the

Hectic of the dying year.

In this mature beauty, which is far more 


\section{Landscape Gardening}

permanent than the more exquisite spring Autumn loveliness, there is a great charm. The meaudy of monotony of July greens has yielded to the deeper tones of the woodland in $\mathrm{Au}$ gust. The declining sun casts longer shadows in the afternoon. The grass along the winding stream, now at its lowest, stands up high from the surface of the water, with darkly shaded edges the more apparent that its prevailing tones are russet with bright golden lights, where the hay has not yet been cut. Here and there the broad expanse shows a hay-cart and a few moving figures, the one touch of life wanting at other seasons to the landscape. The rounded hay-cocks in the distance are lightly shaded on the side opposite the light. There are streaks of red-brown where some of the grass is in blossom, and of vivid green where masses of sedges line the low banks of the tiny winding river, in which their reflections tone the blue through soft gradations to the deepest shadow. A solitary heron floats above the marsh, beating the air with slow strokes of his broad wings. In the evening sometimes the clanging of the wild 


\section{The Rescue of an Old Place}

A fight of geese is heard, the first deep tone in the knell of dying summer. Now and then a white flight of gulls comes up from the harbor searching for fish, pouncing down behind the grass after some luckless perch in the water. The shadows of the distant Oaks are darkest blue, and some far-off Elms fleck the front of an orangecolored cottage and subdue it to harmony. The gray roofs and red chimneys of the distant houses and barns, half-buried in foliage, seem an essential of the picture, giving it that touch of humanness without which a landscape lacks its final charm. The veranda rail, with its drapery of Woodbine, gives a strong accent that brings out the values of the middle distance, while the tops of two old Apple-trees, laden with fruit, make a pleasing curve in contrast to the level lines of the party-colored marsh, elsewhere broken by the ashy-green foliage of some graceful Willows across the invisible road.

So much, at least, our landscape gardening has accomplished; the ugly line which killed our predecessor has been obliterated by our border-plantation, and, 


\section{Landscape Gardening}

to all intents and purposes, the great The meastretch of grassy meadow, with its winding park. stream and its bounding masses of Oak and Maple woods, is our own park, for none of its owners get the good of it as we do. For us it glows with sunshine, or frowns with a passing cloud; ours all this wealth of jasper and chrysoprase and turquoise; as much ours as the silver sheen of the Willows which wave so softly gray against it, and rest the eye from the dazzling tints in which the old marsh arrays herself for the mowers. But the problem that vexes our spirits is that unshaped foreground, and how it may be made to blend more completely with the meadow into one harmonious whole. If the great Apple-tree could but change places with a certain Elm, that is of no use in the landscape where it stands, the matter would settle itself. Two more Apple-trees to cut down, and you have a composition.

But a Seek-no-further, which bears several barrels of early apples that are very Good apples must not be good eating, is not easily to be sacrificed, even to the demands of a landscape, to which it is also advantageous from its 


\section{The Rescue of an Old Place}

height and mass, that could not be reproduced by any tree planted in our day, unless, indeed, we had the purse of Miss Catherine Wolfe to spend thousands in moving giants. If it could be had for the asking, I think I should choose a low, wide-spreading Oak rather than a stately Elm, or possibly the view might be improved if we had no tree at all, but that effect we have from an upper window, which may have its balcony some day.

$A$ destructive wind.

A whirlwind swept up the valley on the twelfth of August, and very nearly settled the question for us by making a clean sweep, but, luckily, contented itself with two or three great boughs full of apples, which are left hanging now by a slip of bark, in hopes that they may get sap enough through this narrow channel to ripen, but it looks doubtful.

The same storm made havoc in the garden with such tall Hollyhocks and Poppies as had carelessly been left untied, and then whisked a branch from off our great Elm, and split in two a large Swamp Maple on the other side of the street. A five-minute tornado it was, with pouring 256 


\section{Landscape Gardening}

flood that swept the main street of the village, and littered it with fallen trunks and limbs twisted off in its whirling flight. As brief, but more violent a gale I have seen in Maine, cutting a forest into windrows, as a mower would cut grass with his scythe.

To make a landscape garden one must $A$ landscape live with it and study it, putting in a touch guires study. here and there, as the painter treats his canvas, now effacing a spot, again adding an accent, blending, harmonizing, even destroying, if need be, and beginning once more. Advice you may listen to, but be not over-hasty to accept suggestion. Weigh each idea well before you admit it, look at it from all sides, for it will always have more than one. It is you who will have to live with the picture, and it is your mind that should lend the individuality that will make the scene your own. It is, after all, the personal touch that is worth while.

A fair woman, who is a summer neighbor of ours, took me the other day through interesting grounds, which her own taste and care had brought into a wild and yet 


\section{The Rescue of an Old Place}

controlled beauty. Boulders draped with vines, and shrubberies of native growth, lined the long avenue that wound up a wooded and rocky hillside to a home which overlooks Massachusetts Bay. But

$A$ viezw of Hingham Harbor from Cohasset.

An abiding memory.

the finest feature of the commanding prospect was a glimpse of the rounded hills and silver-shining water of Hingham Harbor, toward which the eye was led over miles of treetops. Just in front was a lawn of perfect turf, golden-green in the low sunlight, and a little way off, against the blue dome of sky, stood up some heavy Cedars, their black masses of foliage giving just the required force of accent to the foreground, throwing far away into the remotest distance the lovely outline of the Blue Hills of Milton.

Such a picture one cannot forget. Intelligence and taste have added to it the last refining touch. Remoteness is here, and sylvan wildness, contrasted with the gentle charm of well-swept turf, and skillfully subordinated groups of flowering shrubs and plants, that complete, but form no jarring note in the beautiful scene. To me it seemed perfection, but with the eye $25^{8}$ 


\section{Landscape Gardening}

of the true artist who loves his work, my hostess noted a ledge here, an obtrusive Oak-top there, which, to her fastidious taste, seemed to intrude. For the true lover of nature works forever at his picture, ever sensitive to a new charm, watchful for a fresh effect, rejoicing in each change, painting with a palette of the Nature's great Mother's blending, on a canvas of parnting. her own contriving, with an impressionism that cannot falsify, and a detail that is never intrusive. In this great school one learns breadth without vagueness, intensity without violence, and softness that cannot be effeminate. The value of atmosphere, the glory of the sky, can never be out of key with the picture, and the "seeing eye," by careful study and patient waiting, can here evolve ideal beauty from material form. 



\section{XXI}

\section{THE WANING YEAR AND ITS SUGGESTIONS}


Season of mists and mellow fruitfulness !

Close bosom-friend of the maturing sun.

KeATS.

Nature never did betray

The heart that loved her; ' $t$ is her privilege Through all the years of this our life, to lead From joy to joy.

WORDSWORTH. 


\section{XXI}

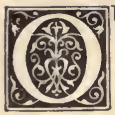

UR season's labor draws to its close, and with it comes a period of rest and reflection, as we turn our thoughts back through this pleasant summer of work and hope.

The charm of a long autumn is very great, but seldom permitted by our capriAutumn charm. cious climate, which is apt to spoil the garden in September, and then make the misfortune the more apparent by a succession of mild October days, when flowers and green leaves would suit the soft warm weather.

This year, which has made eccentric shifts of all the months in turn, giving us a dry April and a cold July, bestowed upon us a most enchanting autumn, mild and free from storms, so that vegetation remained perfect till late October, and the harvest-time was most propitious.

$$
26_{3}
$$




\section{The Rescue of an Old Place}

$A$ delayed frost.

Autumn tints.
No early frost blighted the cornfield, or marred the golden pumpkin's fairness. No rain made the apple and pear gathering a disappointment and a sorrow. Late flowers lined the garden-walks in unchilled splendor until mid-October, while the soft September haze and the mellow glow of the suceeding month showed Maples in full green leaf, and Oaks with only a touch of ripened crimson.

When the autumn comes thus slowly to maturity, a tinge of russet and gold creeps softly into the landscape. Here and there is the accent of a red leaf or branch, like the note of a trumpet in an orchestra. Soft browns steal into the meadows, and form a shade on northern slopes. Dead are the Goldenrods and Asters, faded the roadside flowers. The Rose-hips make ruddy gleams in the bushes, and a few belated Barberries cling to their thorny stems in wizened splendor, while other berries, purple and black, cluster by the fences, and the nut-trees hang out their smooth or prickly burrs, promising a harvest of brown fruit.

This is the green old age of the year, 264 


\section{The Waning Year and its Suggestions}

cheery and fruitful, bountiful and rich. The old age Gone are the hurry of spring and the burof the year.

den of summer, the slow harvest has been gathered, and repose has come to the teeming earth. Now must the gardener look forward and plan for the coming season, and set his bulbs for spring blooming, and clear away the rubbish of dead stems from the flower-beds, and transplant perennials that they may blossom freely the following summer.

It is well in planting a garden to arrange for this season, which is so pleasing, by having a profusion of hardy plants that are not easily disheartened by a chill, and make a brave show as the year wanes. This is a care often neglected by public gardeners, who stock their parterres with ephemeral blooms that the first cold breath destroys, leaving but a dreary group of dry sticks behind.

Well mingled with these more delicate Late blosplants should be those hardy perennials that lift their gallant little heads and smile in the very teeth of winter. The hardy Chrysanthemum, the Marigold, and Calendula are a delight in the late autumn, with $26_{5}$ 


\section{The Rescue of an Old Place}

their cheery tints. The Salvia, less hardy, is the glory of a September garden, and many another flower, with a little shelter at night, will make a walk gay and cheerful that would otherwise be gloomy with decay and desolation. The Japanese Anemone is a treasure at this season, and those bushes bearing ornamental fruit, which hangs on even amid the snows of winter, should never be omitted from a border.

Comfort

Like a happy temper in adversity is a gleam of color in the garden in the late autumn. One draws a lesson of good cheer from a Calendula, so undaunted and gay even when the snows are falling on its golden head. A cluster of red berries on a dry stem gives a distinct joy in early winter, and life is made brighter by the aspect of hardy blossoms and hardier fruit when all the trees around are stripped of foliage.

In summer the charm of a garden is in its coolness and shade, in the dark shelter of thick trees and the quiet of a shaded arbor. In the autumn we seek the sunshine and desire color and warmth, wish266 


\section{The Waning Year and its Suggestions}

ing to forget the coming cold and the swift fading of leaf and flower.

It is like the natural clinging of man to life which increases as years steal upon him. Youth does not dread death as age Youth dreads death less than the aged. shrinks from it. The habit of living becomes stronger as we descend the hill, and the suggestion of interruption seems impertinent. The late scentless flowers are more precious than the summer Roses, for their time will soon be gone. Nature cheats us with her autumn splendor, which beguiles the mind into forgetting that it is the precursor of decay. While we admire the glory of a Maple grove, we do not realize that the storms of winter are gathering behind the forest. When the mountains are purple in the low sunlight, we forget the snows that shall soon whiten their summits, and there is wisdom in this natural instinct that forbids foreboding when joy is at hand, which can enjoy the present without seeking to lift the curtain of the future.

Let us rejoice, then, in the autumn flow- Rejoice in ers ; in the soft atmosphere that clothes the autumn ers; in the soft atmosphere that clothes glory. the world with beauty; in the great 267 


\section{The Rescue of an Old Place}

moon's yellow light; in the round, soft clouds, and the wild scurry of the dun rack that scuds across the heavens when the breeze rises. Full soon will that searching wind scatter the jewel-like leaves, and tear the last petal from the shrinking flowers, while the grass grows brown and sear, and the soft earth stiffens, like a body from which life has departed. Too soon will the valiant head of the last Daisy be buried in a mantle of snow, and the leaden sky bend low above a frozen earth. Let us be glad then while we may, for the days shorten, and with them our summer joys, and the lives of the autumn flowers.

But as the summer wanes, and we turn once more from nature to our own minds for refreshment and solace, we begin to consider what the year's efforts have brought to us, and to reflect what is the serious lesson taught by all our labor, and to sum up our inward experiences, before we take that account of our material stock with which this simple record is to close. No experiment is really valuable which does not conduce to the mind's growth, 268 


\section{The Waning Year and its Suggestions}

and therefore amid these frolicsome records of disaster and enjoyment, I would wish to insert this one didactic chapter, which may easily be skipped by those who seek amusement only, in reading this little book, in which I can emphasize in a few words the effect of out-of-door interests upon the mind and moral nature of those who enjoy them. And I do this the more willingly because I believe that a taste for gardening is one of the elemental impulses of humanity. There are individuals without it, as there are people without sight or hearing or a sense of smell; but, on the whole, to dig comes naturally to man, and at some time or other in the course of his existence the desire to own a portion of the earth's surface is apt to seize upon him, and demand satisfaction.

This impulse is of maturity rather than of youth, for gardening in its larger sense A sign of is a thoughtful pursuit, appealing to the broader qualities of the understanding. It is not merely the desire for healthful exercise which stirs a man, but also the wish to learn the secrets of our common mother, to force her hand, as it were, and 


\section{The Rescue of an Old Place}

compel her to reward his toil. The fable of the giant Antæus, who renewed his strength when he came in contact with the earth, has a subtle meaning, for it is by this contact that many weary souls have found rest and arisen refreshed.

To him who is tired of mankind the solitude and peace of a garden have a rare charm. Many a great statesman has turned from the cares of state to till his fields, or cultivate his flower-beds and trees, his alert brain finding full range for its activity in some scheme of landscape, or some great project for fertilizing a barren waste and rendering it productive.

Gardening gratifies the thoughtful mind, because it does not look for immediate results. It inculcates patience in all its teachings, - patience not only with processes, but with results, for disappointments have often to be met; the best of schemes fail of accomplishment, new enemies arise on every hand, visible and hidden. To combat them requires perseverance, fertility in resource, promptness in action. 


\section{The Waning Year and its Suggestions}

The gardener's life can never be purely contemplative. However fair his domain, he must perforce keep his eyes open in it, and his mind active. Vigilance must be his attribute, or he will have cause for regret. By watching he learns what to do, and what to leave undone, the habits of the plants he tends, their needs, their uses, the different phases of their beauty. Unconsciously he becomes educated, and his mind lays up new stores of facts and deductions for future use.

The planter also grows in unselfish zeal as his plans increase in scope. He pre- toil helps the pares for the future race, not alone for his own joy. The trees he disposes for another generation to sit under; he plants timber for the heir to cut; he adds to his broad acres that he may leave them to his children. For himself the toil, for others the fruit of his labors ; and thus, setting aside his own recompense, he comes into a larger manhood, into that fullness of life which only belongs to him who has forgotten self, and lives for an end he cannot hope to see.

From all this training should result en- 


\section{The Rescue of an Old Place}

Moraltrain- durance of unavoidable evils, fortitude in ing from a garden. disappointment, serenity of mind. Thus the garden shows itself to be a school of the higher virtues, of patience, of tranquillity, of vigilance, of fortitude, of unselfishness and high serenity.

More lessons than these it teaches, therefore small wonder that the groping soul of man, ever seeking higher things, turns to this simplest pursuit as a child to its mother, finding in her arms comfort for his unrest. Unconsciously he seeks this school, which is so great a help to his spirit, and thinks often it is the pure air and exercise alone that have given tone to his nerves, and fresh vigor to his understanding.

Its best effect But, after all, the best thing the garden on man. does for man is to imbue him with a love of home, to anchor him to that one spot of the earth's surface which he calls his own, and to which he can impart some portion of his own individuality. The acres he has tilled, the garden-plot he has watered, will always be dear to him and to his children, and it is this desire for a home and an inheritance for those who shall come 


\section{The Waning Year and its Suggestions}

after him, that drives him to the purchase of land and the beginning of agriculture.

A man who owns a freehold in his The impor country becomes of account at once; it frechold. lifts him from the position of a transient into the dignity of a resident; he gives hostages to fortune; he becomes an established citizen, in place of a possible tramp, and is of more value in the community forthwith. The effect upon himself is elevating and composing. It stills his restlessness, allays ennui, turns the current of his mind into new channels, provides him with an amusement for his leisure hours, while giving occasion for healthful exertion, as well as stimulating wholesome thought. It is opposed to morbidness, it forbids subjectivity, it rouses the imagination, and gratifies the love of beauty.

There is that fine largeness of quality in it as an amusement that appeals to the simplest minds, as well as to the most comprehensive. It is this which proves that it is elemental and human to love a garden, to enjoy the soil, to find comfort in watching the development of plants 


\section{The Rescue of an Old Place}

and trees, and joy in their blossom and fruitage.

Needs of the In America we need just this to give us American. stay and balance. In the older world, where habits are more established, the taste is strong. Here it is overgrown by many things. In so great a land as ours one portion of the soil seems not enough for the citizen. He wants a ranch in Colorado, an Orange-grove in Florida, a seaside home on the coast of Maine, in addition to his city dwelling. But as the crowd increases, and the nation ages, more and more will men concentrate their energies upon one spot, and the love of home and locality will grow more intense, as it is apt to do in the human being when years bring greater quiet to his spirit, and make rest his choicest blessing.

Outcome of the love of gardens.
When we are at last sure that our children will be content to reap what we have sown, to repose under the trees that we have planted, solidity and peace will come to us, and life will grow more simple and more pleasurable to our people. Then will the garden be the true pleasureground, and its wise stillness will pervade 
The Waning Year and its Suggestions

the character of the men who find its cul- Needed ture a real education, and there learn the lessons. needed lessons of perseverance, and patient waiting for the good the future brings, - leading lives without hurry, full of calm interest in their surroundings, and with no wish for change.

275 



\section{XXII}

UTILITY VERSUS BEAUTY 
Happy art thou, whom God does bless With the full choice of thine own happiness ;

And happier yet, because thou 'rt blest With prudence how to choose the best : In books and gardens thou hast placed aright

(Things which thou well dost understand, And both dost make with thy laborious hand) Thy noble, innocent delight.

Abraham Cowley.

The trumpet of a prophecy! $O$ wind, If winter comes, can spring be far behind?

SHELLEX. 


\section{XXII}

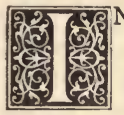

$\mathrm{N}$ spite of all the moral effects of the garden upon the philosoA trial to the temper. pher within us, I am constrained to confess that it has its trials for the average temper, and that. in that development of patience for which it works, there is a good deal of stumbling by the way, during the battle between the useful and the ornamental; for on any moderate-sized place, with only a man or two to do the necessary work, there is a constant conflict between what is of present importance, and what serves for future adornment.

This is one reason why we like to have as many things done in the autumn as can safely be accomplished at that time, because of all seasons of the year the spring is the one when everything comes at once, and your factotum is more than 


\section{The Rescue of an Old Place}

ever distracted by the various calls upon his time and attention.

The spring scurry.

I used to wonder why farmers were always behindhand with their work, and, while apparently idle part of their time, were driven to death for about two thirds of the year; but I have discovered that the weather is responsible for a good deal, first by being cold and perhaps wet in the spring, so that the ground cannot be tilled until late, and then suddenly sending everything ahead by a few unseasonable days of heat and sunshine. Then there is a scurry for the hitherto impracticable digging of the vegetable-garden, a headlong rush to get the seeds in; the grass, which always interferes at unseasonable moments, demands the lawn-mower, and will not wait a minute. The shrubs that you have been waiting to move until the weather should be mild enough to permit your superintending the operation (one can cope with a piercing east wind for this purpose, but not with a northwest snowstorm) shake off their icicles, and all at once begin to leave out; in a day or two it will be too late. If there is 280 
a tree that you have intended to plant at this season the complications are increased, for setting a tree properly is a work of time, and delay here is dangerous.

The perennials need overhauling and replanting in the flower-garden; the weeds are rushing ahead and choking everything; you want your man to attend to them when he has to be putting in peas and potatoes for your future sustenance.

The whole spring is one breathless moment, through which you are rushed helter-skelter, leaving half your needs untoo soons. attended to ; and while you are still endeavoring to catch up with the work, all of a sudden our headlong summer bounces into haying time, and the hapless beautifier is worse off than ever.

Of what account are trees and shrubs and flowers, or even the ever-clamoring lawn itself, when the fields are to be shorn, and possible thunderstorms lurk low along the horizon? This is the weeds' moment, and they avail themselves of it promptly. Up comes the Chickweed among the peas and corn; the flower$28 \mathrm{r}$ 


\section{The Rescue of an Old Place}

garden fairly bristles with Plantains and Mallows, and the paths are slippery with Purslane. On the lawn the Dandelions begin to intrude, and go to seed when they are only an inch high, lying down deceitfully under the lawn-mower, and poking up their white plumes the minute it has passed in the most imperturbable manner.

The harvest overrules everything.

It is of no use to summon any one. "That grass must be cut to-day," or " the hay must be turned, or forked over, or got in, or whatever" - there is no appeal ; harvest-claims take precedence, and the weeds nod their heads at each other, and say "Come along!" and life is to them a beautiful holiday.

By the time the last load of hay has been safely stowed away, these same weeds have to be coped with, for they have become a forest, and that still further postpones the time when the rsthetic side of your place can really have any consideration given to it. At last, when you do get round to it, it is too late to do anything, and one can only sit down and make plans for another season, which will again be 282 


\section{Utility versus Beauty}

buried out of sight, in the rush which is sure of a periodical return.

For this reason August is a month which I delight in, for then there is a August a useful month. moment's breathing-space before the fruit harvest and the terrible "second crop" are again upon the carpet. It is a good time for grading and sodding before the autumn rains. With care, and a ball of earth, some of the hardy shrubs can be moved; if it has been a dry summer, now is the chance to put in some evergreens and to remodel your beds of dwarfs. But no sooner do we get fairly to work, and the general effect begins to improve and ideas to take shape, than the marsh, which usually claims the whole late fall, and the months of March and April, puts in an appeal for drainage, and, presto! the men who were engaged in ornamental work are whisked away, and you can only see the tops of their heads above the edge of a pile of dirt, as they burrow their way along an unsightly ditch.

Then comes September with its pears and apples. Your own fruit is a fine thing

Pearsatireto have in theory, beautiful to look for- 


\section{The Rescue of an Old Place}

ward to, something to be proud of, but it is a tremendous burden when it comes. The gathering is an important labor, but taking care of it when it is gathered is infinitely worse. The pears, especially, must be watched daily, turned and selected, and the refuse rejected, till their owner would be happier if he never saw a Bartlett or a Jargonelle again. The early apples, welcome and useful as they are, demand the closest attention, and it is not until the last Russet is gathered, and barreled, and stowed away in the cellar for winter use, that the amateur farmer can have an easy mind.

Profit in a

Perhaps it would be wiser to choose between ornamental and useful management of a place to begin with, and content yourself with either a farm or a garden, as the case might be ; but in this event, though one would probably have better results to show, he would miss much of the fun of the more helter-skelter methods of landscape-practice, as well as the profits of orderly market-gardening, which can never be very successful in the hands of amateurs. There is, however, a sense of profit 284 
in your own garden as an accessory, whatever statistics show, which is not to be foregone; and, as to the pleasure of getting trees and shrubs in their proper places, who that has read these chapters can doubt that they are a source of amusement and instruction alike, even to the most unpractical of their protectors?

The problems of the old place will con- The puzzle tinue to develop and add puzzle to puzzle $\begin{gathered}\text { gives pleare } \\ \text { sure. }\end{gathered}$ in our uninstructed minds; we may pay dear for our whistle, but we shall have the whistle anyhow. After a few more years of experiment and failure, or success, as the wheel turns, we shall probably come to the conclusion to let the grass and shrubs grow as they will under the trees, and let the rest go, which will, I am disposed to think, be wholly to the advantage of the looker-on. But while some vestige of vigor is left to us, we shall think the puzzle part more interesting than the solution, and so struggle happily on, setting for ourselves ingenious examples, to be painfully worked out perhaps to a wrong result. Interest in the place will be less when we can no longer tinker at it 285 


\section{The Rescue of an Old Place}

to advantage, but to that excitement will possibly succeed the calm enjoyment of those who sit under the tree they have planted, and partake of the fruits of their own vine.

The new into the old. whose tops we could look down three

As we look up to-day to the trees, upon years ago, we begin to realize the profit of our labors, and to feel that we may even live to take pride in them. The birds which sing in their branches, and build their nests among the twigs, thank us sweetly for the shelter thus provided, though their harmonious chatter adds to the precariousness of a morning nap. The shrubs expand with vigor, the flowers we have planted flaunt gayly, the vines are climbing to the roof-tree. The spot not long ago so desolate and unpromising is now sheltered and verdant. The dull red walls of the house have taken on a mantle of green, as it begins to nestle into the shadow of the upreaching branches, that will erelong overtop its chimneys. The raw freshness has largely disappeared, the new place is melting into the old, and in a few years more people will have forgotten, as they 
so soon do, the former conditions, and will cease to realize the importance of the changes made.

The beauty of stately expanses, of deep solitudes, of extensive lawns, and broad park-like spaces, we can never attain, but travelers on the village highway will look kindly through the overarching trees and say, "A pleasant home is there, and a fair outlook on a quiet scene."

Already the Willows of the boundary stretch up to hide us from the rear. The Summer departs.

Pines are showing dark once more, against the hill sunbrowned by the September sun. Yellow leaves are shining on the Elms and Birches, and the shrill wind streaks the green grass with bright-hued foliage, torn from the Maple boughs. The gay-colored blossoms of autumn flowers gleam from the shrubberies, and the lowdeclining sun casts long shadows across the turf. Soon will a nipping frost bestrew the lawn with wrecks of summer glory; the birds are gathering for their southern flight; the year is past its prime. A few short weeks of hectic color, and then the end, the sleep, the long dull silence of 287 


\section{The Rescue of an Old Place}

winter, the sheets of snow, the chains of ice, that bind the earth until her re-awakening.

September How swift the silent succession of the chases Fune.

months! September seems to tread upon the train of June, it is so quickly here, so quickly gone. The Goldenrod is the first plume of the year's hearse, yet when its earliest yellow feathers wave we burn under the hot breath of summer, but ere they lose all their gold, the hand of death is on the grass, and the brown leaves have fallen.

Autumn

A cold rain patters on the gravel walk, and the branches of the trees are dripping as they hang unstirred. The sky is gloomy and leaden, - one vast gray cloud sullenly enwraps the heavens. There is no hope, no outlook; all is sad and drear, - rain over head, a wet earth under foot. Summer has gone; the chill of autumn is here. But hark! what is that murmur? It is the northwest wind blowing his distant horn, and in a twinkling the leaden skies are broken with windows of light. The gray scud whisks up toward the zenith, the wet trees shake off their burden, and wave 288 
joyfully in the keen breeze. October October

comes! What though his tramp is over comes.

the dead leaves! He comes like a warrior from battle, fresh and strong, inspiriting and brave. "Be not cast down!" he cries, "by the death of fair summer. Bold winter succeeds to the throne. $\mathrm{He}$ is a king worth having, and his reign shall restore your vigor, men of the north! He helps to make you what you are! Behind him, hidden by his furry mantle, lurks the spring, and then once more the dead summer shall be reborn, and the world shall be again all blossom and music!"

So with this bracing note, October Vale ? passes on, while, cheered by hope and softened by memory, we leave the old place to sleep awhile, and turn to our winter fire, and the companionship of men and books, in lieu of birds, and trees, and flowers, which have gladdened us for half a year. 





A 
